\title{
Fire Tests of Brick Walls
}

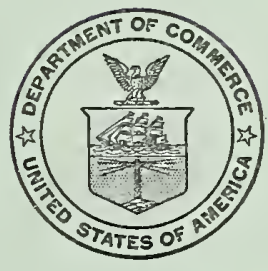

United States Department of Commerce

National Bureau of Standards

Building Materials and Structures Report 143 


\section{BUILDING MATERIALS AND STRUCTURES REPORTS}

On request, the Superintendent of Documents, U. S. Government Printing Office, Washington 25, D. C., will place your name on a special mailing list to receive notices of new reports in this series as soon as they are issued. There will be no charge for receiving such notices.

If 100 copies or more of any report are ordered at one time, a discount of 25 percent is allowed. Send all orders and remittances to the Superintendent of Documents, U.S. Government Printing Office, Washington $25, D$. C.

The following publications in this series are available by purchase from the Superintendent of Documents at the prices indicated:

BMS1 Research on Building Materials and Structures for Use in Low-Cost Housing . . - .-. BMS2 BMS3

BMS4

BMS5

BMS6

BMS7

BMS8

BMS9

Methods of Determining the Structural Properties of Low-Cost House Constructions -

Suitability of Fiber Insulating Lath as a Plaster Base

Accelerated Aging of Fiber Building Boards

Structural Properties of Six Masonry Wall Constructions.

Survey of Roofing Materials in the Southeastern States.

Water Permeability of Masonry Walls

Methods of Investigation of Surface Treatment for Corrosion Protection of Steel

Structural Properties of the Insulated Steel Construction Co.'s "Frameless-Steel" Con-

BMS10 Structural Properties of One of the "Keystone Beam Steel Floor" Constructions Spon-

BMS11 Structural Properties of the Curren Fabrihome Corporation's "Fabrihome" Construc-

BMS12 Structural Properties of "Steelox" Constructions for Walls, Partitions, Floors, and Roofs, Sponsored by Steel Buildings, Inc

BMS13 Properties of Some Fiber Building Boards of Current Manufacture.....

BMS14 Indentation and Recovery of Low-Cost Floor Coverings by the Wheeling Corrugating Co.

BMS16 Structural Properties of a "Tilecrete" Floor Construction Sponsored by Tilecrete Floors, Inc . .

BMS17 Sound Insulation of Wall and Floor Constructions Supplement to BMS17, Sound Insulation of Wall and Floor Constructions... Supplement No. 2 to BMS17, Sound Insulation of Wall and Floor Constructions.-
BMS18 Structural Properties of "Pre-Fab" Constructions for Walls, Partitions, and Floors Sponsored by the Harnischfeger Corporation

BMS19 Preparation and Revision of Building Codes BMS20 Structural Properties of "Twachtman" Constructions for Walls and Floors Sponsored

by Connecticut Pre-Cast Buildings Corporation
BMS21 Structural Properties of a Concrete-Block Cavity-Wall Construction Sponsored by the
National Concrete Masonry Association

BMS22 Structural Properties of "Dun-Ti-Stone" Wall Construction Sponsored by the W. E. BMS23 Structural Properties of a Brick Cavity-Wall Construction Sponsored by the Brick BMS24 Structural Properties of a Reinforced-Brick Wall Construction and a Brick-Tile Cavity-

WMS25 Structural Properties of Conventional Wood-Frame Constructions for Walls, Partitions,

BMS26 Structural Properties of "Nelson Pre-Cast Concrete Foundation" Wall Construction

Sponsored by the Nelson Cement Stone Co., Inc
BMS27 Structural Properties of "Bender Steel Home" Wall Construction Sponsored by the

BMS28 Backflow Prevention in Over-Rim Water Supplies. BMS29 Survey of Roofing Materials in the Northeastern States.: BMS30 Structural Properties of a Wood-Frame Wall Construction Sponsored by the Douglas

Fir Plywood Association
BMS31 Structural Properties of "Insulite" Wall and "Insulite" Partition Constructions
Sponsored by The Insulite Co.

- Out of print.

t Superseded by BMS116.

[List continued on cover page III] 


\title{
Fire Tests of Brick Walls
}

\author{
S. H. Ingberg
}

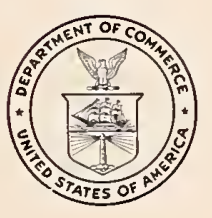

Building Materials and Structures Report $1+3$

Issued November 30, 1954 



\section{Foreword}

Brick walls of buildings have been generally recognized as effective means of restricting the spread of fire and reducing the loss from conflagrations in builtup areas. Their effectiveness depends upon their stability under fire conditions and the prevention of ignition of combustible materials near or in contact with the side not exposed to fire.

The present paper gives results of a comprehensive series of fire tests conducted under controlled conditions to determine the essential properties of brick walls as fire barriers. Besides walls of the usual solid design, a number of hollow walls were included with bricks laid flat or on edge to form one or more unfilled spaces between the brick wythes.

The information should be useful in attaining economy with the required degree of fire safety in buildings where bricks are used for exterior walls and interior subdividing constructions.

A. V. Astin, Director. 


\section{Contents}

Foreword

1. Introduction

2. Materials

2.1. Brick

a. Clay bricks .

b. Shale brick

c. Concrete bricks

d. Sand-lime bricks _...........

e. Size of bricks

2.2. Mortar

a. Materials $\ldots$

b. Proportions

2.3. Plaster

c. Strength

3. Test walls

3.1. Design
a. Solid walls
b. Rolok walls
c. Rolok-bak design
d. Rolok-faced design

3.2. Size

a. Large walls

b. Small walls

3.3. Workmanship
a. Construetion methods

b. Rate of laying bricks

3.4. Auxiliary strength tests of masonry -..-

a. Test specimens

b. Strength of solid masonry _......

c. Results with the rolok design ....

3.5. Seasoning of walls

a. Large walls

b. Small walls

4. Testing equipment and methods

4.1. Panel frames

4.2. Furnace equipment

4.3. Loading and restraint $\ldots \ldots \ldots \ldots \ldots$

4.4. Furnace fire exposure

a. Furnace control curve

b. Pyrometer mounting

d. Unprotected furnace thermocouples -

4.5. Determination of wall temperatures...

4.6. Calibration of thermocouples.

4.7. Deflection measurements _...........

4.8. Hose-stream tests

5. Program of tests

5.1. Solid walls

5.2. Walls of hollow design

5.3. Fire and hose-stream tests.........

6. Results of fire-endurance tests

6.1. Criteria of fire-endurance limit ......

a. Limits of surface temperature rise -

b. Temperature rise within the wall. -

c. Residual temperature rise .......

d. Lateral deflection

6.2. Results with solid-wall constructions . -

a. Walls of 4-in. thickness
(1) Temperature-rise limits $\ldots$

(2) Time-temperature curves .--

(3) Lateral deflections

b. Clav-and shale-brick walls of 8-in.

thickness _._. _.

(1) Surface-temperature limits.-

(2) Wall-temperature limits

(3) Effect of drying at elevated temperatures...........

(4) Loading, restraint, and lateral deflection.........

(5) Effect of cracks and imperfect joints
6. Results of fire-endurance tests-Continued

6.2. Results with solid-wall constructions-Con.

c. Concrete and sand-lime brick walls of 8-in. thickness ..........

(1) Surface-temperature rise wall-carrying ability and lateral deflections _....

(4) Cracks and other fire effects -

d. Solid walls of 12-in. thickness

(1) Surface-temperature limits . -

(2) Temperature rise in wall ..-

(3) Lateral deflection

(4) Cracks and imperfect joints

(5) Fusion of brick and mortar

(6) Failure under load

6.3. Results with walls of hollow designs _... a. Hollow walls of 8-in. thickness..--

(1) Surface-temperature limits

(2) Temperature limits in wall

(3) Restraint, loading, and lateral deflections.

(4) Cracks and other fire effects -

b. Hollow walls of 12-in. thickness

(1) Surface-temperature limits .

(2) Temperature limits in wall

(3) Cracks and other fire effects.

c. Cavity walls

(1) Temperature-rise limits

(2) Loading and deflection .....

(3) Cracks and open joints....

6.4. Temperature rise after test..........

6.5. Ignition of cotton and excelsior pads . -

7. Results of fire and hose-stream tests........

7.1. Performance under fire exposure

7.2. Stability and integrity

7.3. Load-carrying ability

a. Walls of 4 -in. thickness

b. Solid and all-rolok walls of 8-in. thickness _.................

c. Solid and all-rolok walls of 12 -in. thickness

d. Cavity walls

7.4. Other wall designs

8. Effect of fire tests on strength of brick and masonry _........................

8.1. Compressive strength of bricks

8.2. Transverse strength of bricks.......

8.3. Absorption

8.4. Masonry strength

9. Summary and conclusions

9.1. Materials of construction

9.2. Workmanship

9.3. Wall constructions

9.4. Testing procedure

9.5. Conditioning before test

9.6. Fire-resistance periods

a. Theoretical relations _..........

b. Loading and stability

c. Average fire-resistance periods ...

(1) Clay- and shale-brick walls of 4 -in. thickness . . . ....

(2) Solid clay- and shale-brick walls of 8- and 12-in. thickness _..............

(3) Solid concrete and sand-lime brick walls of 8- and 12-in. thickness_..............

(4) Walls of all-rolok and alternate rolok designs .......

(5) Cavity walls

(6) Walls of other designs 


\section{Fire Tests of Brick Walls}

\section{S. H. Ingberg}

Fire-endurance tests were conducted of 5-1 solid and 19 hollow brick walls, supplemented by 10 fire and hose-stream tests.

The fire-resistance limit of 4 -in. clay and shale brick walls was found to be about $11 / 4 \mathrm{hr}$, as based on stability under fire exposure, ability to carry load, and to protect combistible material on the side not exposed to fire. Plaster on both sides increased the limit to $2 \frac{1}{2} \mathrm{hr}$.

For clay and shale brick solid walls of 8-in. thickness, the fire-resistance limit from the above considerations was $5 \mathrm{hr}$, which was increased to $7 \mathrm{hr}$ when the walls were plastered on both sides. For combustible members projecting into the walls 4 in. from the unexposed side, the protection period was $2 \mathrm{hr}$, and if plastered, $3 \mathrm{hr}$. With the 12 -in. nominal thickness, the fire-resistance limits ranged from 8 to $10 \mathrm{hr}$, depending upon the fusion temperature of the bricks, and with $7 \mathrm{hr}$ as the protection period for framed-in members.

For solid 8- and 12-in. walls of concrete and sand-lime bricks, the fire-resistance limits were found 1 to $2 \mathrm{hr}$ higher than for comparable walls of clay and shale bricks. This was apparently due to the retarding effect on temperature rise in the wall from evaporation of the combined water in the brick cementing material.

The fire-resistance limit of 8-in. clay and shale brick walls of the all-rolok design was $2 \frac{1}{2} \mathrm{hr}$, and with framed-in combustible members, $1 \mathrm{hr}$. With plaster, these were increased to $4 \mathrm{hr}$ and $1 \frac{1}{2} \mathrm{hr}$, respectively. For 12 -in. rolok walls, a fire-resistance limit of $5 \mathrm{hr}$ was indicated, and $2 \frac{1}{2} \mathrm{hr}$ as the protection period for members supported in the wall. For the plastered wall, these were $7 \mathrm{hr}$ and $3 \frac{1}{2} \mathrm{hr}$, respectively.

For cavity walls of 10-in. nominal thickness, the fire-resistance period averaged about $5 \mathrm{hr}$, with $1 \frac{1}{2}$ or $2 \mathrm{hr}$ as the protection period for supported combustible members, depending upon the degree of embedment assumed.

All wall constructiors evidenced ability to meet the performance in the fire and hosestream test required for their respective fire-resistance ratings.

\section{Introduction}

Brick walls when used as fire and party walls in buildings have a well-established record in restricting the spread of fire, although prior to these tests there were few data.extant on their performance in standardized fire tests. Information on such performance has become necessary in that building-code requirements for fire resistance are now in considerable part based upon performance tests that have been substituted for or supplement requirements formerly designated in terms of material, design, and thickness of walls in given situations.

In general, this enables a wider choice of materials and design, not only to meet fire-resistance requirements but also with respect to considerations of economy and other purposes served by the construction.

The present series consisted of 54 fire-endurance tests of solid and 19 of hollow-type brick walls in a number of designs, and 10 fire and hose-stream tests of typical solid and hollow-type brick-wall constructions. The nominal thickness was in the range 4 to $12 \mathrm{in.}$

The first tests were begun in 1921 and continued at intervals thereafter. These tests were made before the fire-testing procedure had been standardized on all particulars. However, sufficient information was obtained in these and later tests to enable the fire resistance for almost all of the construction types and designs to be eraluated in terms of performance, using the procedure now recognized as standard.

\section{Materials}

\subsection{Brick}

The walls for the present series of tests were built of clay bricks from three States, shale bricks from one, and sand-lime and concrete bricks cateh from three sources.

\section{a. Clay Bricks}

The clay bricks were made from so-ralled surface clays, the sources and symbol for each being as given in table 1.

The brick from Maryland, designated Cl.Ml. was made from a red plastic chy by the so-called "soft-mud" machine-moleling process. amel hat il gritty surface from dusting the molels with fine sand. 'The softening point of the burned material was neal $1,475^{\circ} \mathrm{C}\left(2,\left(55^{\circ} \mathrm{F}\right)\right.$ ( (one 17$)$. 
TABLE 1. Strength and absorption of bricks

\begin{tabular}{|c|c|c|c|c|c|c|c|}
\hline \multicolumn{3}{|c|}{ Brick } & \multirow[b]{2}{*}{ Wall or test ${ }^{2}$} & \multicolumn{2}{|c|}{ Compressive strength } & \multirow[b]{2}{*}{$\begin{array}{l}\text { Modulus } \\
\text { of rupture }\end{array}$} & \multirow{2}{*}{$\begin{array}{l}\text { Absorption } \\
\text { (5-hr. } \\
\text { boiling) }\end{array}$} \\
\hline Type & Locality & $\begin{array}{l}\text { Type and } \\
\text { source } \\
\text { symbol } 1\end{array}$ & & On side & On edge & & \\
\hline 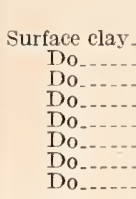 & $\begin{array}{l}\text { Md } \\
\text { IId } \\
\text { MId........ } \\
\text { Md.... } \\
\text { Ill } \\
\text { Ill } \\
\text { N. Y } \\
\text { N. Y }\end{array}$ & 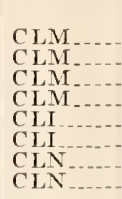 & $\begin{array}{l}1,11,14,15,38,54,64 \\
16,17 \\
2,18 \\
3,4,8,9,12,37,39,41,42,60 \text { to } 63,65 \text { to } 69 \\
19 \text { to } 21,43,55 \text { to } 57 \\
44 \\
70,71,72\end{array}$ & $\begin{array}{r}l b / i n .^{2} \\
3,280 \\
3,130 \\
2,960 \\
2,960 \\
2,920 \\
3,280 \\
3,580 \\
2,920\end{array}$ & $\begin{array}{r}l b / \text { in. } 2 \\
2,560 \\
1,960 \\
2,940 \\
3,040 \\
2,330 \\
3,350 \\
\end{array}$ & $\begin{array}{c}l b / i n .2 \\
760 \\
1,210 \\
920 \\
890 \\
1,180 \\
1,230 \\
450 \\
420\end{array}$ & $\begin{array}{r}\text { Percent } \\
15.6 \\
15.6 \\
14.5 \\
14.7 \\
22.5 \\
16.7 \\
20.0 \\
19.8\end{array}$ \\
\hline $\begin{array}{l}\text { Shale } \\
\text { Do...... } \\
\text { Do }\end{array}$ & $\begin{array}{l}\text { W. } \mathrm{Va} \\
\text { W. Va } \\
\text { W. Va }\end{array}$ & $\begin{array}{l}\mathrm{SH} W \\
\mathrm{SH} W \\
\mathrm{SH} W\end{array}$ & $\begin{array}{l}5,22,23,58 \ldots \\
6,59, \\
10 \mathrm{~A}\end{array}$ & $\begin{array}{r}8,110 \\
6,450 \\
10,040\end{array}$ & $\begin{array}{l}6,400 \\
5,640 \\
7,410\end{array}$ & $\begin{array}{l}2,020 \\
1,570 \\
2,760\end{array}$ & $\begin{array}{r}6.5 \\
10.2 \\
5.6\end{array}$ \\
\hline $\begin{array}{l}\text { Concrete } \\
\text { Do } \\
\text { Do }\end{array}$ & $\begin{array}{l}\text { N. Y } \\
\text { D. C } \\
\text { D. C.- }\end{array}$ & $\begin{array}{l}\text { CON } \\
\text { COD } \\
\text { COE }\end{array}$ & $\begin{array}{l}25,26,45 \\
49 \\
28,50\end{array}$ & $\begin{array}{l}2,780 \\
2,920 \\
3,350\end{array}$ & $\begin{array}{l}1,530 \\
2,290 \\
2,490\end{array}$ & $\begin{array}{l}650 \\
780 \\
800\end{array}$ & $\begin{array}{l}13.5 \\
10.8\end{array}$ \\
\hline $\begin{array}{l}\text { Sand-lime } \\
\text { Do } \\
\text { Do } \\
\text { Do } \\
\text { Do }\end{array}$ & $\begin{array}{l}\mathrm{Pa} . \\
\mathrm{D} . \mathrm{C} \\
\mathrm{D} \cdot \mathrm{C} \\
\mathrm{D} \cdot \mathrm{C} \\
\text { Ohio }\end{array}$ & $\begin{array}{l}\text { SLP } \\
\text { SLD } \\
\text { SLD } \\
\text { SLT } \\
\text { SLO }\end{array}$ & $\begin{array}{l}29 \text { to } 31,51 \text {. } \\
31 \\
32 \\
35\end{array}$ & $\begin{array}{l}4,630 \\
2,050 \\
3,050 \\
2,020 \\
3,600\end{array}$ & $\begin{array}{l}4,720 \\
1,690 \\
2,550 \\
2,000 \\
3,000\end{array}$ & $\begin{array}{l}930 \\
460 \\
850 \\
540 \\
800\end{array}$ & $\begin{array}{l}16.4 \\
20.7 \\
24.3 \\
20.8 \\
14.5\end{array}$ \\
\hline
\end{tabular}

1 These symbols are used throughout the text and tables.

2 Some of the bricks were also used in building walls for fire and hose-stream tests, for which the wall numbers are not here included.

The Illinois brick (CLI) was made by the extrusion "stiff-mud" end-cut process from a calcareous clay. Its softening point was near $1,145^{\circ} \mathrm{C}$ $\left(2,095^{\circ} \mathrm{F}\right)$ (cone 01).

The New York, or Hudson River, brick (CLN) was made by the same process as the Maryland brick from a surface clay to which a small amount of powdered coal was added to increase the porosity. The average coefficient of expansion in the temperature range up to $900^{\circ} \mathrm{C}$ was about 0.0000068 . This comes within the lower range reported for such material [1]. ${ }^{1}$

\section{b. Shale Brick}

Shale brick from West Virginia (SHW) rras made from a typical shale by the extrusion "stiffmud" side-cut process. The softening point of the burned brick material was near $1,305^{\circ} \mathrm{C}$ $\left(2,381^{\circ} \mathrm{F}\right)$ (cone 10$)$.

\section{c. Concrete Bricks}

The concrete brick from New York (CON) was made from a mix of 1 part of portland cement to 5 parts of siliceous sand by volume. The sand contained 60 to 70 percent of quartz, the rest being micaceous and feldspathic minerals.

In making the brick, the wet mix was contained

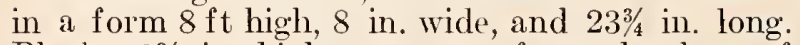
Blocks $3 \frac{3}{4} \mathrm{in}$. high were cut from the base of this column, from each of which 10 bricks on edge were cut. The mix in the form was compacted by the dropping incidental to the successive removal of blocks from its base.

The bricks were cured for 4 days in moist air heated to normal indoor temperatures, af ter which they were stored outside.

\footnotetext{
1 Numbers in brackets refer to references at the end of this report.
}

The concrete brick (COD) from the District of Columbia was made from a damp mix of 1 part of portland cement to 6 parts of coarse (concrete) sand, proportioned by volume. The sand, Potomac River, consisted of 50 to 60 percent of quartz, the rest being micaceous and feldspathic minerals, some of which carried iron compounds.

The molding by the dry-tamp process was followed by steam curing at $20-\mathrm{lb} / \mathrm{in}^{2}{ }^{2}$ pressures for 24 to $36 \mathrm{hr}$.

The concrete brick (COE) was also made in the District of Columbia of the same type of materials and concrete mix as the COD brick and cured by similar process.

\section{d. Sand-Lime Bricks}

The sand-lime brick from Pennsylvania (SLP) was made with a sand obtained by mixing and clushing the clean waste from a brownstone quarry and stone-cutting plant. From 95 to 100 percent of it passed No. 10 (0.073 in.) mesh; 75 to 85 percent, No. 40 (0.015 in.) mesh; and about 20 percent, No. 100 (0.0055 in.) mesh. Chemical analysis of the sand indicated about 90 percent of silica, 6 percent of alumina and iron oxides, the rest being lime, magnesia, soda, and potash.

The high-calcium quicklime used was hydrated as mixed with about four parts of sand, the mixture being previously pulverized in a tube mill. More sand was added in the final mix to give a proportion of 1 part of quicklime to about 17 parts of dry sand by weight. The brick was molded in machines under high pressure and then hardened under 30 - to $35-\mathrm{lb} / \mathrm{in} .^{2}$ steam pressure for 10 to $11 \mathrm{hr}$.

The sand-lime brick from the District of Columbia (SLD) was made with a bank sand containing about 90 percent of quartz, the rest being largely 
orthoclase feldspar: The mix was in the proportion of 1 part of high-calcium hydrated lime to 9 parts of sand by weight, the lime being hydrated at the plant previous to mixing. The bricks were molded br machine under high pressure and then hardened under 120-lb/in. ${ }^{2}$ steam pressure for $10 \mathrm{hr}$. The sand-lime brick from Ohio (SLO) was made with a sand consisting of a mixt ure of siliceous and dolomitic ninerals. This was mixed with highcalcium lime and enough portland cement to give the required strength in the hardening process under steam pressure.

\section{e. Size of Bricks}

The arerage dimensions of the bricks from a given source were within $1 / 8$ in. of $2 \frac{1}{4}$ in. for the thickness, within $1 / 4$ in. of $3 \frac{3 / 4}{\mathrm{in}}$. for the width, and within $1 / 4 \mathrm{in}$. of $8 \mathrm{in}$. for the length, except for the sand-lime brick (SLD), which was $2 \frac{3}{8}$ to $2 \frac{1}{2} \mathrm{in}$. thick, $4 \frac{1}{3}$ to $4 \frac{1}{2}$ in. wide, the average length being $\delta_{, 4}^{3 / 4}$ in. They were all solid without cores or scoring, except that clay brick CLN had a formed depression, or "frog", on one side equivalent to about 15 percent of the rolume.

\section{f. Strength and Absorption of Bricks}

The trpes and sources of the bricks are given in table 1. together with the numbers of the walls for fire-endurance tests built from each lot. Also included in this table are average compressive strengths determined with half bricks on side or edge, the modulus of rupture on 7 -in. span, and the water absorption by 5-hr boiling. These determinations were made in accordance with methods given in the standards of the American Society for Testing Materials. The number of determinations on which arerage results are based ranged from 5 to 50 or more.

\subsection{Mortar}

The proportions and strength of the mortar used for laring up the walls are given in table 2 .

\section{a. Materials}

The portland cement and lime were obtained from local dealers and were tested to determine conformity with accepter standards. Both the quick lime and hydrate were of the high-calcium type.

The sand, dredged from the Potomac River, contained about 95 percent of siliceous minerals, mainly quartz, the rest being of micaceous and feldspathic type. In fineness, all of it passed No. 4 sieve; about 95 percent, No. 16 sieve; 20 to 25 percent, No. 50 sieve; and 4 to 5 percent, No. 100 sieve.

\section{b. Proportions}

Although the proportions are given by volume, the quantities were obtained by weight. A bag of portland cement weighing $\dot{9} 4 \mathrm{lb}$ and one of hydrated lime weighing $50 \mathrm{lb}$ were taken as 1 and $1 \frac{1}{4} \mathrm{ft}^{3}$, respectively. The dry contents of $1 \mathrm{ft}$ of sand was taken as $78 \mathrm{lb}$, except that for $1: 1: 6$ mortar an 80-lb equivalent was taken. The amount of mixing water to be used was left to the discretion of the mason but weighed for each batch of mortar.

\section{c. Strength}

The compressive strength of the mortar was determined with 2-in. cubes, one or more of which were taken from each batch and stored near the test walls under similar atmospheric conditions. The results in table 2 are segregated by age and also by water content of the mix, where specimens were numerous enough to give dependable averages.

The results indicate that, in general, for the cement-lime mortars there was an increase in strength with age and a decrease in strength with increase in water content of the mix. The $1: 1 \frac{1}{2}: 6$ mortar had lower strength than the $1: 1 \frac{11}{4}: 6$ mortal, due apparently to higher lime and sand content. However, the difference probably had no effect on the fire resistance of the walls.

TABLE 2. Compressive strength of mortar for laying up walls.

\begin{tabular}{|c|c|c|c|c|c|c|}
\hline \multirow{2}{*}{ Type of mortar } & \multicolumn{2}{|c|}{$\begin{array}{l}\text { Proportion cement, } \\
\text { hydrated lime, and sand }\end{array}$} & \multirow{2}{*}{$\begin{array}{l}\text { Number } \\
\text { of walls }\end{array}$} & \multirow{2}{*}{$\begin{array}{l}\text { Water con- } \\
\text { tent }{ }^{1} \text { of mix } \\
\text { range }\end{array}$} & \multirow{2}{*}{$\begin{array}{l}\text { A verage } \\
\text { age }\end{array}$} & \multirow{2}{*}{$\begin{array}{l}\text { A verage } \\
\text { strength }\end{array}$} \\
\hline & $\begin{array}{l}\text { By dry } \\
\text { weight }\end{array}$ & $\begin{array}{l}\text { By nominal } \\
\text { volumes }\end{array}$ & & & & \\
\hline Lime.... & $\begin{array}{l}0: 50: 234 \\
0: 50: 234\end{array}$ & $\begin{array}{l}0: 11 / 4: 3 \\
0: 11 / 4: 3\end{array}$ & $\begin{array}{l}3 \\
3\end{array}$ & $\begin{array}{c}\text { Percent } \\
26.9 \text { to } 31.3 \\
26.7 \text { to } 30.7\end{array}$ & $\begin{array}{c}D a y s \\
62 \\
140\end{array}$ & $\begin{array}{c}\text { bo/in. } \\
60 \\
55\end{array}$ \\
\hline $\begin{array}{l}\text { Cernent-lime } \\
\text { Do } \\
\text { Do } \\
\text { Do } \\
\text { Do }\end{array}$ & $\begin{array}{l}94: 60: 468 \\
94: 60: 468 \\
94: 60: 468 \\
94: 50: 468 \\
94: 50: 468\end{array}$ & $\begin{array}{l}1: 11 / 2: 6 \\
1: 1 \frac{2}{2}: 6 \\
1: 1 \frac{1}{2}: 6 \\
1: 1 \frac{1 / 4}{1}: 6 \\
1: 1 \frac{1}{4}: 6\end{array}$ & $\begin{array}{r}8 \\
12 \\
6 \\
6 \\
4\end{array}$ & $\begin{array}{l}21.7 \text { to } 25.0 \\
25.1 \text { to } 36.2 \\
25.1 \text { to } 36.2 \\
19.9 \text { to } 23.0 \\
19.0 \text { to } 23.0\end{array}$ & $\begin{array}{r}64 \\
71 \\
326 \\
62 \\
215\end{array}$ & $\begin{array}{l}310 \\
180 \\
220 \\
3+1 \\
540\end{array}$ \\
\hline 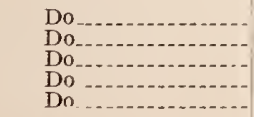 & $\begin{array}{l}94: 50: 468 \\
94: 50: 468 \\
94: 50: 468 \\
94: 50: 468 \\
94: 40: 480\end{array}$ & $\begin{array}{l}1: 11 / 4: 6 \\
1: 1 \frac{1}{4}: 6 \\
1: 11 / 4: 6 \\
1: 11 / 4: 6 \\
1: 1: 6\end{array}$ & $\begin{array}{r}25 \\
13 \\
11 \\
3 \\
3\end{array}$ & $\begin{array}{l}23.1 \text { to } 26.0 \\
23.1 \text { to } 26.0 \\
26.1 \text { to } 30.6 \\
26.1 \text { to } 30.6 \\
23.4 \text { to } 25.4\end{array}$ & $\begin{array}{r}63 \\
109 \\
70 \\
186 \\
43\end{array}$ & $\begin{array}{l}340 \\
450 \\
2(x) \\
2 \times 0 \\
550\end{array}$ \\
\hline $\begin{array}{c}\text { Cement } \\
\text { Do }\end{array}$ & $\begin{array}{l}94: 0: 234 \\
94: 0.234\end{array}$ & $\begin{array}{l}1: 0: 3 \\
1: 0: 3\end{array}$ & $\begin{array}{l}2 \\
2\end{array}$ & $\begin{array}{l}22.5 \text { to } 23.0 \\
22.3 \text { to } 23.5\end{array}$ & $\begin{array}{r}61 \\
172\end{array}$ & $\begin{array}{l}s, 50) \\
s(y)\end{array}$ \\
\hline
\end{tabular}

1 Based on total weight of dry materials. 


\subsection{Plaster}

The lime, portland cement, and neat fibered gypsum plaster with which the sanded plaster was made were obtained from local dealers, and in point of quality passed accepted test requirements. The sand was from the same source and of the same fineness as used for the mortar.

The plaster was proportioned by weight of dry materials. The compressive strength, as determined with 2 -in. cubes taken from each batch and stored near the test walls, is given in table 3.

The plaster was applied in two coats to a total thickness of $1 / 2$ to $5 / 8$ in. No white-coat finish was applied.

\begin{tabular}{|c|c|c|c|c|}
\hline Type of plaster & $\begin{array}{c}\text { Propor- } \\
\text { tions, } \\
\text { by dry } \\
\text { weight }\end{array}$ & Wall & Age & $\begin{array}{l}\text { A verage } \\
\text { strength }\end{array}$ \\
\hline Lime & $\left\{\begin{array}{l}1: 21 / 2 \\
1: 3 \\
1: 3 \\
1: 3\end{array}\right.$ & $\begin{array}{l}10 A \\
42 \\
60 \\
63\end{array}$ & $\begin{array}{c}\text { Days } \\
70 \\
65 \\
54 \\
67\end{array}$ & $\begin{array}{c}l b / \text { in }_{.}{ }^{2} \\
90 \\
80 \\
25 \\
60\end{array}$ \\
\hline Cement & $1: 23<$ & 8 & 62 & 740 \\
\hline Gypsum . - & $\left\{\begin{array}{l}1: 3 \\
1: 3 \\
1: 3 \\
1: 3 \\
1: 3 \\
1: 3\end{array}\right.$ & $\begin{array}{r}9 \\
37 \\
61 \\
62 \\
66 \\
67\end{array}$ & $\begin{array}{l}61 \\
67 \\
61 \\
67 \\
67 \\
98\end{array}$ & $\begin{array}{l}590 \\
500 \\
640 \\
920 \\
470 \\
740\end{array}$ \\
\hline
\end{tabular}

\section{Test Walls}

\subsection{Design}

The walls of the present series of tests were of solid or of hollow types, as shown in figures 1 and 2 .

\section{a. Solid walls}

The conventional designs of solid walls are shown in figure 1 ( $A$ to $C$ ) and of a $4-i n$. wall with pilasters in figure 2 .

The 4-in. walls were laid with vertical joints broken, that is, with the joint opposite the middle third of the length of the bricks immediately above or below them. The wythes of the 8-in. walls and outside wythes of the 12 -in. walls were similarly laid. In the same course the stretchers in 8- and 12-in. walls were laid with end joints in alinement in some walls, and in others they were broken. With two otherwise similar walls, one was built to each detail on this particular. There was one header course for every five stretcher courses.

\section{b. Rolok Walls}

With the rolok designs, the bricks in all or the greater number of courses are laid on edge with the bond broken vertically. The all-rolok design indicated by $\mathrm{D}$ and $\mathrm{F}$ in figure 1 has stretchers and headers, all on edge. In design $G$, allstretcher courses alternate with all-rolok courses. In design $\mathrm{H}$, two stretcher courses on edge alternate with a bonding course having bricks laid on side with two headers for each stretcher.

\section{c. Rolok-Bak Design}

For the 8-in. wall, figure $1, \mathbf{E}$, a common bond with bricks laid flat is attained for the facing, the backing having four stretcher courses on edge per header course laid with bricks on side. For the 12-in. wall, design $J$, the same bond is attained for the facing, and the backing has three stretcher courses on edge alternating with two bond courses, one with headers on edge and the other with headers and stretchers laid flat.

\section{d. Rolok-Faced Design}

As per design $\mathrm{K}$ of figure 1, the all-rolok facing is attained for a 12-in. wall with three all-rolok courses alternating with a rolok course having false (half-brick) headers. The backing has three stretcher courses on edge alternating with a solid header course of bricks on edge.

\section{e. Cavity Design}

In the cavity type, design $\mathrm{L}$ in figure 1 , two 4 -in. wythes with bricks laid flat were tied together with metal ties in every sixth course spaced $2 \mathrm{ft}$ apart horizontally. In the walls of the present tests, the ties were Z-shaped and of coppercoated steel wire 0.20 in. in diameter.

\subsection{Size}

\section{a. Large Walls}

The large walls were built into frames with openings $16 \mathrm{ft}$ wide and 10 or $11 \mathrm{ft}$ high, corresponding to the size of wall for those tested restrained within the panel frame. For those tested unrestrained or under load, the length was decreased 2 to $3 \mathrm{in}$. by the clearance between the wall and the frame, and similarly for the height of unrestrained walls. For walls tested under load, the height was $10 \mathrm{ft} 4$ in. One wall, No. 10, was built in two sections of 7 -ft 9 -in. and $7-\mathrm{ft} 10-\mathrm{in}$. respective widths.

\section{b. Small Walls}

The frames into which the small walls were built had openings $4 \mathrm{ft} 2$ in. wide and high. As for the large walls, the clearance at the ends of walls tested under load reduced the width of the wall by about 2 in. 

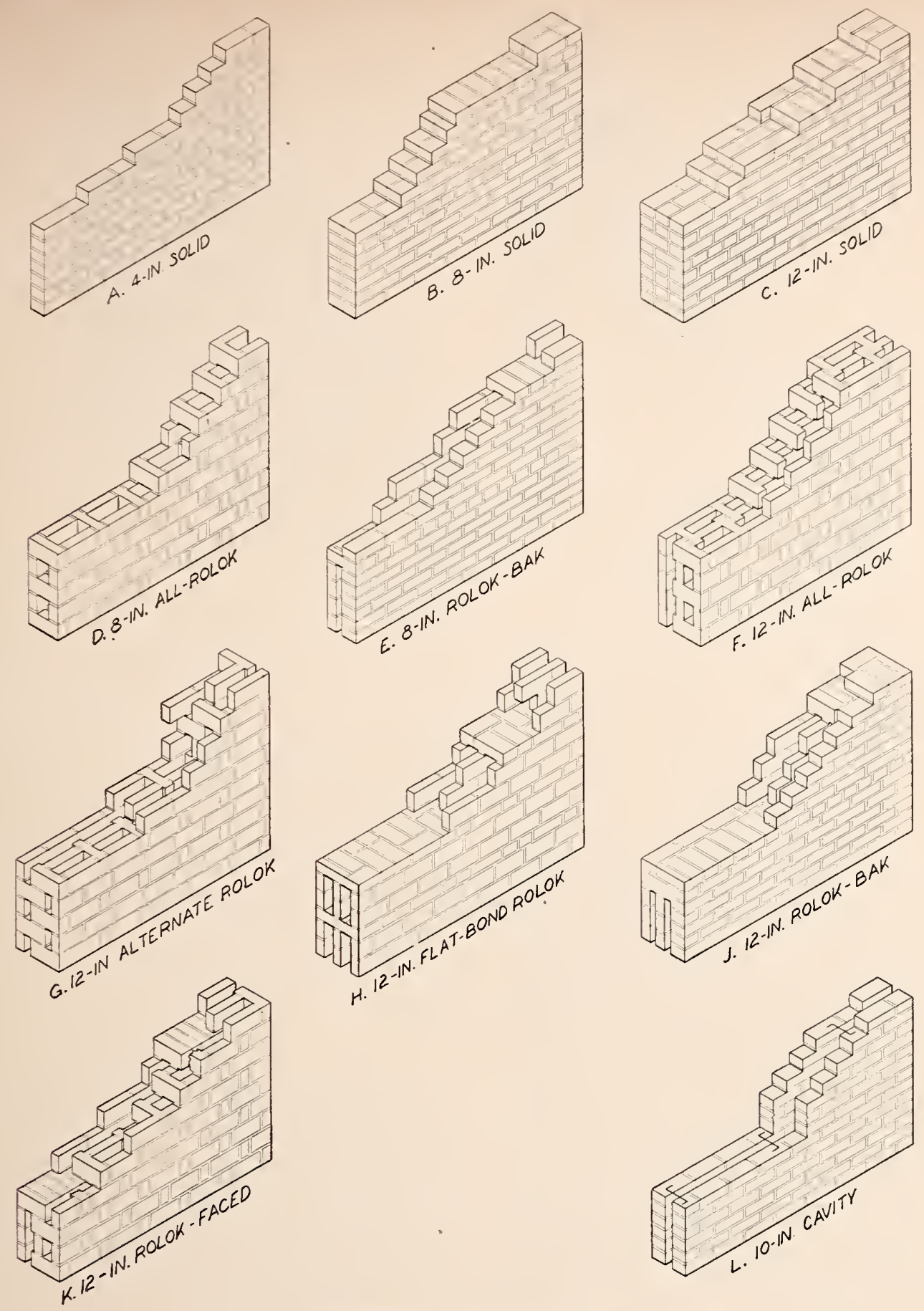

Figure 1. Design of walls. 

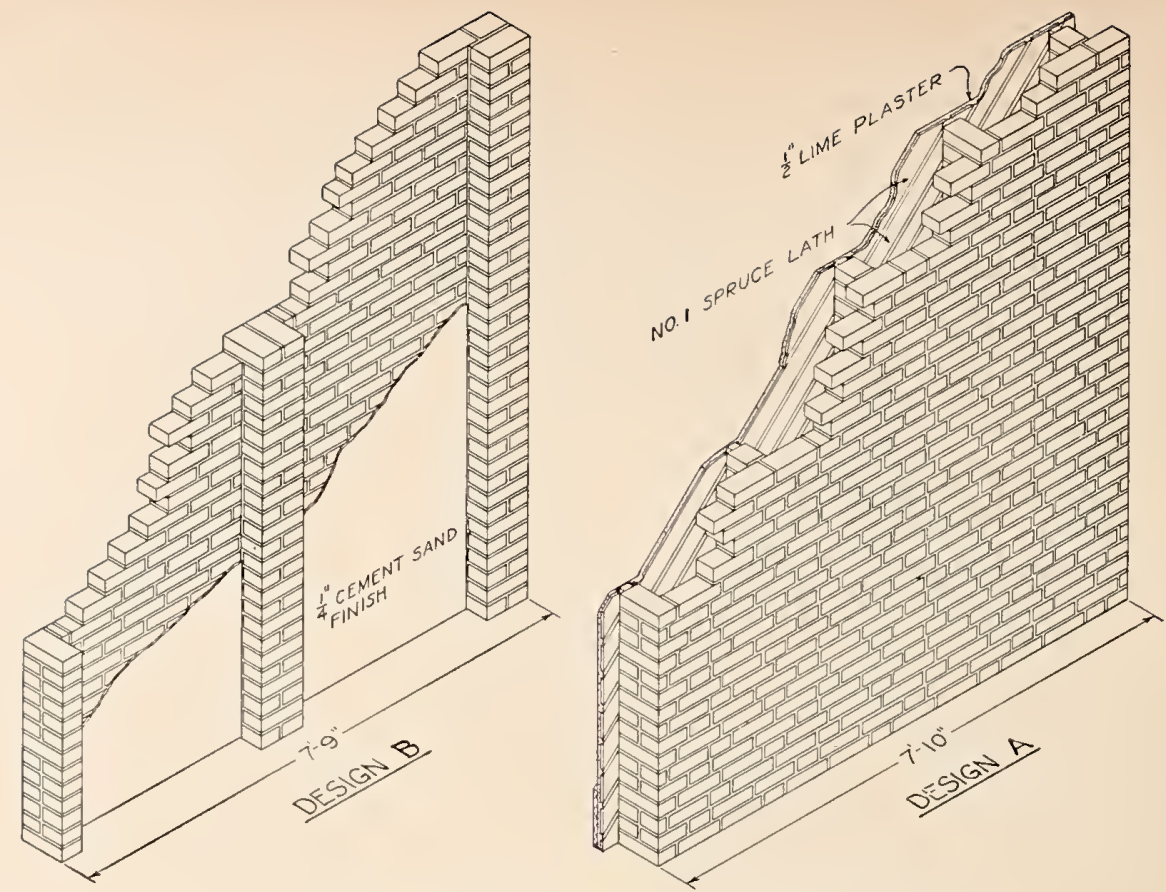

Figure 2. Design of 4 -in. wall with pilasters.

\subsection{Workmanship}

\section{a. Construction Methods}

Almost all of the large walls were built by contract given to the lowest bidder, with the stipulation that only experienced masons be employed. Observations were made on methods and rate of laying bricks, the degree to which joints were filled, and related construction details. From 1,000 to 3,300 bricks were required to lay the different walls, each wall requiring the time of one mason from 1 to over 3 days, so that the ordinary work routine might be expected.

Brick stretchers on side in solid walls were uniformly laid by the "spread-and-lay" method, the mason spreading mortar bed for 2 to 5 bricks at a time. Mortar was generally applied to the bricks on only one outside vertical edge before being laid in place with little or no shoving. Mortar was applied to headers near both ends of the long side and sometimes for the greater part of their length. The spread for the following course filled the transverse joints in both stretcher and header course to some extent, and they were found, on the average, three-fourths full on examination after test. The longitudinal joint between stretcher courses in the 8-in. solid walls was found from one-fourth to three-fourths full. In 12-in. solid walls, the longitudinal joints were more nearly filled, the outside stretcher courses being laid first and the center course laid in mortar slushed in between the outside bricks. The thickness of mortar joints was in the general range of 0.40 to $0.60 \mathrm{in}$.

For bricks set on edge in hollow rolok walls, mortar was spread for the bed joint of several bricks and applied to one vertical edge of stretchers and near both ends on both sides of headers. Somewhat more shoving and tapping of bricks for the rolok walls were necessary than for bricks laid flat. The bed joints were found nearly uniformly filled and vertical joints three-fourths full on the average.

\section{b. Rate of Laying Bricks}

The rate of laying bricks in the large walls built on contract varied from 625 to 1,960 bricks per mason per 8-hr day, depending upon the type and thickness of wall, the skill and number of masons working on a given wall, and the number and efficiency of the helpers. The lower rates were obtained with 1 mason and helper laying 4-in. walls and with 3 or 4 masons working on thicker walls, the highest rates being for 1 mason and 2 helpers working on 8-in. solid walls.

The average rate of laying for 8- and 12-in. hollow rolok walls was 910 bricks per mason per 8-hr day, the time required to construct walls of equal area and thickness being nearly the same as for solid walls. The rolok walls required from 25 to 30 percent less brick than solid walls of equal area and thickness.

In table 4 the rate of laying bricks in the large walls is given in terms of man-hours per $100 \mathrm{ft}^{2}$ of 
TABLE 4. Time required for construction of walls

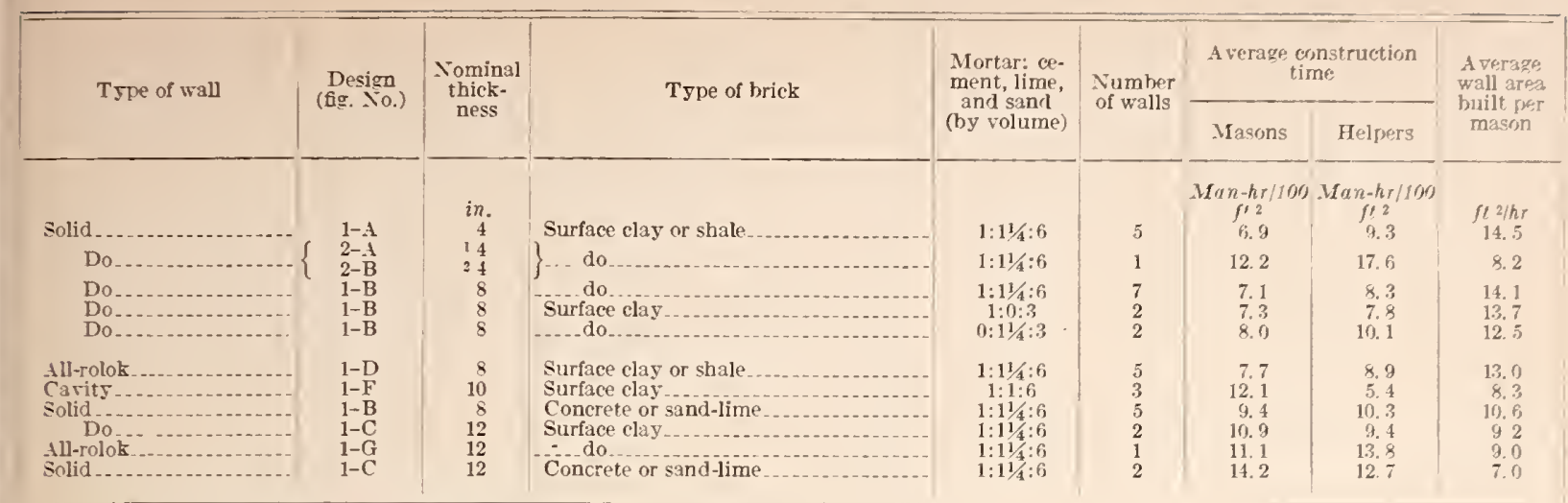

${ }^{1}$ Pilasters 4 by 4 in., 1-ft 9 in. centers for one half of wall.

2 Pilasters 4 by 8 in., 3 -ft 9 in. centers for other half of wall.

wall and the arerage area of wall built per mason per hour.

The comparatively low rate of laying bricks for 4-in. and cavity walls, considering the relative number of bricks involved, is apparently due in large part to the greater care needed to keep the newly laid masonry on line. The rate for the 4-in. walls with pilasters and for the hollow rolok walls was also attributable to the masons' lack of experience in laying these types, as compared with laring the usual 8-and 12-in. solid walls. As for differences indicated in the table for type of brick and mortar, the conditions were not uniform in point of number and skill of masons and helpers working on given walls, for which due allowance should be made in considering the nominally comparable figures. 'The arerages also comprise figures for fire walls built by a mason in Government employ.

Except for the 4-in. wall with pilasters, none of the large walls were plastered. The face joints were struck and pointed, although not as uniformly as would be required on a commercial job. In point of filling of interior joints and similar construction details, the workmanship was apparently barely up to the average in commercial building construction.

Five of the large walls and all of the small walls were built by masons in the employ of the Government, with the grade of workmanship probably a little above the commercial average.

\subsection{Auxiliary Strength Tests of Masonry}

\section{a. Test Specimens}

At the time of building the walls for fire tests, an auxiliary masonry pier was built for almost all of the large walls and for a few of the small walls. These were 2 to 3 bricks long, or $16 \frac{1}{2}$ to 25 in., the arerage height being near $2 \mathrm{ft} 6 \mathrm{in}$. The piers had aged 55 days or'more at the time of test, and further seasoning probably would not have materially increased their strength. They were tested in compression, with results as summarized in table 5, and the weight loss in seasoning up to the time of testing is also given.

The table further includes results of strength tests of piers cut from walls after fire-endurance or fire and hose-stream tests. For some of the small walls, the whole test wall was subjected to the compression test after cooling, with some regain in strength subsequent to the fire-endurance test.

\section{b. Strength of Solid Masonry}

The average results indicate a strength for the solid piers in the lower range of values, of four or more times the $160 \mathrm{lb} / \mathrm{m}^{2}{ }^{2}$ working load applied to 8- and 12-in. walls tested under load in the fireendurance tests. The strength with the portlandcement mortar was higher, and with the lime mortar lower than for the cement-lime mortar, with which most of the solid walls and all of the hollow walls were laid. The average strength of masonry piers laid in lime mortar was $62.5 \mathrm{lb} / \mathrm{in} .^{2}$

In general, the strength of masonry increased with the strength of the brick, although the relation varied considerably as a result of other properties, including the bond obtained with the mortar. The high compressive strength dercloped by the 4 -in. walls is apparently attributable to the absence of headers, the early breaking of which in 8- and 12-in. walls contributed to fitlute at lower load.

\section{c. Results with the Rolok Design}

The strength for the rolok-trpe lollow wall with bricks set on edge was lower than for solid walls. being as an average ouly a little more than three times the load of $160 \mathrm{lb} / \mathrm{in}^{2}{ }^{2}$ applied in the fireendurance tests. Howerer, according to buildingcode requirements, the permitted working stress for hollow walls of brick is lower, being in the range 80 to $125 \mathrm{lb} / \mathrm{in} .{ }^{2}$ of gross area. 
TABLE 5. Compressive strength of brick piers

\begin{tabular}{|c|c|c|c|c|c|c|c|c|c|c|c|}
\hline \multicolumn{4}{|c|}{ Brick } & \multicolumn{4}{|c|}{ Fire-test walls } & \multirow{3}{*}{$\begin{array}{l}\text { Mortar: } \\
\text { cement, } \\
\text { lime, and } \\
\text { sand (by } \\
\text { volume) }\end{array}$} & \multirow{3}{*}{$\begin{array}{c}\text { A verage } \\
\text { age }\end{array}$} & \multirow{3}{*}{$\begin{array}{c}\text { Weight } \\
\text { loss in } \\
\text { seasoning }\end{array}$} & \multirow{3}{*}{$\begin{array}{l}\text { Compres- } \\
\text { sive } \\
\text { strength } \\
\text { of piers }\end{array}$} \\
\hline \multirow{2}{*}{ Kind } & \multirow{2}{*}{$\begin{array}{l}\text { Type and } \\
\text { source } \\
\text { symbol }\end{array}$} & \multicolumn{2}{|c|}{ Compressive strength } & \multirow{2}{*}{ Wall } & \multirow{2}{*}{ Type } & \multirow{2}{*}{$\begin{array}{l}\text { Design } \\
\text { (figure } \\
\text { No.) }\end{array}$} & \multirow{2}{*}{$\begin{array}{l}\text { Nominal } \\
\text { thickness }\end{array}$} & & & & \\
\hline & & On side & On edge & & & & & & & & \\
\hline 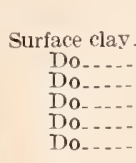 & $\begin{array}{l}\text { CLM } \\
\text { CLMI } \\
\text { CLM } \\
\text { CLMI } \\
\text { CLMI } \\
\text { CLM }\end{array}$ & $\begin{array}{r}l b / \text { in. }^{2} \\
3,280 \\
3,280 \\
3,280 \\
3,280 \\
3,280 \\
3,280\end{array}$ & $\begin{array}{r}l b / i n .2 \\
2.560 \\
2,560 \\
2,560 \\
2,560 \\
2,560 \\
2,560\end{array}$ & $\begin{array}{r}1 \\
11 \\
38 \\
54 \\
64 \\
14,15\end{array}$ & $\begin{array}{l}\text { Solid } \\
\text { do } \\
\text { All-rolok } \\
\text { Solid. }\end{array}$ & $\begin{array}{l}1-A \\
1-B \\
1-C \\
1-D \\
1-G \\
1-B\end{array}$ & $\begin{array}{r}\text { in } \\
4 \\
8 \\
12 \\
8 \\
12 \\
8\end{array}$ & $\begin{array}{l}1: 11 / 4: 6 \\
1: 11 / 4: 6 \\
1: 114: 6 \\
1: 11 / 4: 6 \\
1: 11 / 4: 6 \\
1: 0: 3\end{array}$ & $\begin{array}{c}\text { Days } \\
182 \\
146 \\
231 \\
135 \\
232 \\
248\end{array}$ & $\begin{array}{r}t b / f t .{ }^{3} \\
5.9 \\
4.5 \\
3.5 \\
3.5 \\
4.9 \\
3.5\end{array}$ & $\begin{array}{r}\text { lb/in.2 } \\
1,170 \\
850 \\
740 \\
530 \\
630 \\
970\end{array}$ \\
\hline $\begin{array}{l}\text { Do... } \\
\text { Do... } \\
\text { Doo... } \\
\text { Do... } \\
\text { Do... } \\
\text { Do... }\end{array}$ & $\begin{array}{l}\text { CLMI } \\
\text { CLM } \\
\text { CLM } \\
\text { CLM } \\
\text { CLM } \\
\text { CLM }\end{array}$ & $\begin{array}{c}3,130 \\
3,130 \\
3,130 \\
2,960 \\
2,960 \\
\end{array}$ & $\begin{array}{r}1,960 \\
1,960 \\
1,960 \\
2,940 \\
2.940 \\
\end{array}$ & $\begin{array}{c}16 \\
17 \\
75 \\
2 \\
18 \\
10 \mathrm{~B}\end{array}$ & 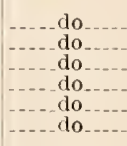 & $\begin{array}{l}1-\mathrm{B} \\
1-\mathrm{B} \\
1-\mathrm{B} \\
1-\mathrm{A} \\
1-\mathrm{B} \\
1-\mathrm{A}\end{array}$ & $\begin{array}{l}8 \\
8 \\
8 \\
4 \\
8 \\
4\end{array}$ & $\begin{array}{l}0: 11 / 4: 3 \\
0: 11 / 4: 3 \\
1: 11 / 4: 6 \\
1: 11 / 4: 6 \\
0: 11 / 4: 3 \\
1: 1 \frac{1}{4}: 6\end{array}$ & $\begin{array}{r}126 \\
409 \\
224 \\
55 \\
77 \\
70\end{array}$ & $\begin{array}{l}2.5 \\
6.7 \\
(1) \\
4.4 \\
4.7 \\
. . . . .\end{array}$ & $\begin{array}{r}510 \\
720 \\
540 \\
1,450 \\
650 \\
1,210\end{array}$ \\
\hline $\begin{array}{l}\text { Do... } \\
\text { Do... } \\
\text { Do... } \\
\text { Do... } \\
\text { Do... } \\
\text { Do... }\end{array}$ & $\begin{array}{l}\text { CLMI } \\
\text { CLMI } \\
\text { CLI } \\
\text { CLI } \\
\text { CLI } \\
\text { CLI }\end{array}$ & $\begin{array}{l}2,920 \\
2,920 \\
2,920 \\
2,920\end{array}$ & $\begin{array}{l}2.330 \\
2.330 \\
2,330 \\
2.330\end{array}$ & $\begin{array}{r}13 \\
40 \\
\text { 19. } 21 \\
75 \\
43 \\
55 \text { to } 57\end{array}$ & $\begin{array}{l}\text { _ do } \\
\text { do do } \\
\text { dll-rolok. } \\
\text { do } \\
\end{array}$ & $\begin{array}{l}1-B \\
1-C \\
1-B \\
1-B \\
1-C \\
1-D\end{array}$ & $\begin{array}{r}8 \\
12 \\
8 \\
8 \\
12 \\
8\end{array}$ & $\begin{array}{l}1: 11 / 4: 6 \\
1: 11 / 4: 6 \\
1: 11 / 4: 6 \\
1: 11 / 4: 6 \\
1: 11 / 4: 6 \\
1: 11 / 4: 6\end{array}$ & $\begin{array}{r}97 \\
98 \\
157 \\
225 \\
157 \\
121\end{array}$ & $\begin{array}{l}(2) \\
(2) \\
5.8 \\
(1) \\
5.5 \\
4.4\end{array}$ & $\begin{array}{l}630 \\
710 \\
530 \\
400 \\
480 \\
450\end{array}$ \\
\hline $\begin{array}{l}\text { Shale } \\
\text { Do... } \\
\text { Do.. } \\
\text { Do... }\end{array}$ & $\begin{array}{l}\text { SHW } \\
\text { SHW } \\
\text { SHW } \\
\text { SHW }\end{array}$ & $\begin{array}{l}8,110 \\
8,110 \\
8,110 \\
6,450\end{array}$ & $\begin{array}{l}6,400 \\
6,400 \\
6,400 \\
5,640\end{array}$ & $\begin{array}{r}5,73 \\
22,23 \\
58 \\
59\end{array}$ & $\begin{array}{l}\text { Solid } \\
\text { All-rolok. } \\
\text { do }\end{array}$ & $\begin{array}{l}1-A \\
1-B \\
1-D \\
1-D\end{array}$ & $\begin{array}{l}4 \\
8 \\
8 \\
8\end{array}$ & $\begin{array}{l}1: 11 / 4: 6 \\
1: 11 / 4: 6 \\
1: 11 / 4: 6 \\
1: 11 / 4: 6\end{array}$ & $\begin{array}{r}174 \\
89 \\
316 \\
59\end{array}$ & $\begin{array}{l}6.3 \\
5.8 \\
4.2 \\
2.4\end{array}$ & $\begin{array}{r}1,880 \\
1,530 \\
1,470 \\
440\end{array}$ \\
\hline $\begin{array}{c}\text { Concrete. } \\
\text { Do.. } \\
\text { Do.. } \\
\text { Do... } \\
\text { Do... }\end{array}$ & $\begin{array}{l}\text { CON } \\
\text { CON } \\
\text { CON } \\
\text { CON } \\
\text { CON }\end{array}$ & $\begin{array}{l}2,780 \\
2,780 \\
2,780 \\
2,780 \\
2,780\end{array}$ & $\begin{array}{l}1,530 \\
1,530 \\
1,530 \\
1,530 \\
1,530\end{array}$ & $\begin{array}{r}73 \\
25 \\
26 \\
75 \\
45,78\end{array}$ & $\begin{array}{l}\text { Solid } \\
\text { do } \\
\\
\end{array}$ & $\begin{array}{l}1-\mathrm{A} \\
1-\mathrm{B} \\
1-\mathrm{B} \\
1-\mathrm{B} \\
1-\mathrm{C}\end{array}$ & $\begin{array}{r}4 \\
8 \\
8 \\
8 \\
12\end{array}$ & $\begin{array}{l}1: 11 / 4: 6 \\
1: 11 / 4: 6 \\
1: 11 / 4: 6 \\
1: 11 / 4: 6 \\
1: 11 / 4: 6\end{array}$ & $\begin{array}{r}238 \\
72 \\
314 \\
226 \\
161\end{array}$ & $\begin{array}{l}8.0 \\
4.0 \\
5.3 \\
\text { (1) } \\
6.1\end{array}$ & $\begin{array}{r}1,250 \\
840 \\
870 \\
440 \\
850\end{array}$ \\
\hline $\begin{array}{l}\text { Do } \ldots \\
\text { Do_... } \\
\text { Do } \\
\text { Do } \\
\text { Do... }\end{array}$ & $\begin{array}{l}\text { CON } \\
\text { CON } \\
\text { COE } \\
\text { COE } \\
\text { COE }\end{array}$ & $\begin{array}{l}2,780 \\
2,780 \\
3,350 \\
3,350 \\
3,350\end{array}$ & $\begin{array}{l}1,530 \\
1,530 \\
2,490 \\
2,490 \\
2,490\end{array}$ & $\begin{array}{l}78 \\
76 \\
28 \\
28 \\
50\end{array}$ & $\begin{array}{l}\text { do } \\
\text { All-rolok } \\
\text { Solid } \\
\ldots \text {. do }\end{array}$ & $\begin{array}{l}1-\mathrm{C} \\
1-\mathrm{D} \\
1-\mathrm{B} \\
1-\mathrm{B} \\
1-\mathrm{C}\end{array}$ & $\begin{array}{r}12 \\
8 \\
8 \\
8 \\
12\end{array}$ & $\begin{array}{l}1: 11 / 4: 6 \\
1: 11 / 4: 6 \\
1: 11 / 4: 6 \\
1: 11 / 4: 6 \\
1: 11 / 4: 6\end{array}$ & $\begin{array}{r}174 \\
192 \\
78 \\
78 \\
78\end{array}$ & $\begin{array}{l}(1) \\
7.4 \\
(2) \\
-\cdots\end{array}$ & $\begin{array}{r}580 \\
440 \\
940 \\
430 \\
1,040\end{array}$ \\
\hline 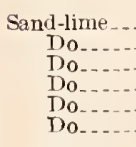 & $\begin{array}{l}\text { SLP } \\
\text { SLP } \\
\text { SLP } \\
\text { SLP } \\
\text { SLP } \\
\text { SLD }\end{array}$ & $\begin{array}{l}4,630 \\
4,630 \\
4,630 \\
4,630 \\
2,060 \\
2,060\end{array}$ & $\begin{array}{l}4,720 \\
4,720 \\
4,720 \\
4,720 \\
1,690 \\
1,690\end{array}$ & $\begin{array}{r}29,30 \\
31 \\
75 \\
51,78 \\
75 \\
75\end{array}$ & 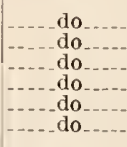 & $\begin{array}{l}1-B \\
1-B \\
1-B \\
1-C \\
1-B \\
1-B\end{array}$ & $\begin{array}{r}8 \\
8 \\
8 \\
12 \\
8 \\
8\end{array}$ & $\begin{array}{l}1: 11 / 4: 6 \\
1: 11 / 4: 6 \\
1: 11 / 4: 6 \\
1: 11 / 4: 6 \\
1: 11 / 4: 6 \\
1: 1 \frac{1}{4}: 6\end{array}$ & $\begin{array}{l}274 \\
217 \\
228 \\
219 \\
221 \\
224\end{array}$ & $\begin{array}{l}4.7 \\
(2) \\
(1) \\
6.0 \\
7.0 \\
(1)\end{array}$ & $\begin{array}{l}840 \\
280 \\
430 \\
890 \\
830 \\
390\end{array}$ \\
\hline $\begin{array}{l}\text { Do... } \\
\text { Do-... } \\
\text { Do-.. } \\
\text { Do... } \\
\text { Do... } \\
\text { Do... }\end{array}$ & $\begin{array}{l}\text { SLD } \\
\text { SLD } \\
\text { SLD } \\
\text { SLO } \\
\text { SLO } \\
\text { SLO }\end{array}$ & $\begin{array}{l}2,060 \\
3,050 \\
3,050 \\
3,600 \\
3,600 \\
3,600\end{array}$ & $\begin{array}{l}1,690 \\
2,550 \\
2,550 \\
3,000 \\
3,000 \\
3,000\end{array}$ & $\begin{array}{l}31 \\
32 \\
32 \\
36 \\
36 \\
53\end{array}$ & 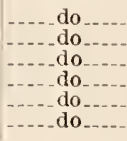 & $\begin{array}{l}1-B \\
1-B \\
1-B \\
1-B \\
1-B \\
1-C\end{array}$ & $\begin{array}{r}8 \\
8 \\
8 \\
8 \\
8 \\
12\end{array}$ & $\begin{array}{l}1: 11 / 4: 6 \\
1: 11 / 4: 6 \\
1: 11 / 4: 6 \\
1: 11 / 4: 6 \\
1: 11 / 6 \\
1: 11 / 4: 6\end{array}$ & $\begin{array}{r}215 \\
69 \\
81 \\
78 \\
78 \\
78\end{array}$ & $\begin{array}{c}(2) \\
-(2) \\
-(2) \\
--\end{array}$ & $\begin{array}{l}230 \\
710 \\
450 \\
730 \\
610 \\
810\end{array}$ \\
\hline
\end{tabular}

\subsection{Seasoning of Walls}

\section{a. Large Walls}

The large walls were stored in the frames within which they were built, with the base of wall about $4 \mathrm{ft}$ above the floor of the building. The frames were suspended from trolley tracks and for the seasoning period were placed $1 \frac{1}{2}$ to $4 \mathrm{ft}$ apart in one end of the building. In cold or damp weather, the drying of masonry was accelerated with three warm-air furnaces, the storage space being segregated from the rest of the building with a canvas curtain.

The age of the large walls at time of the fireendurance test ranged from 28 to 100 days, in general, the longer seasoning period being allowed for the thicker walls. A measure of the degree of dryness at time of test was obtained by weighing at intervals the companion piers built for compression tests. The fire test was not conducted until there was no loss indicated in the weight of the pier on successive weighings at intervals of a few days or until the loss was small. The piers were tested from 2 weeks to over 1 year after the fire test of the companion wall, and the weighings of the piers in the interval indicate the weight loss the walls subjected to the fire test might have had on longer aging.

In general, the data indicate that although most of the test walls had not reached constant weight at the time of the fire test under the seasoning conditions concerned, the further loss in weight for walls of clay and shale bricks would have been no more than 10 or 15 percent of the loss up to the time of the fire test. However, if the seasoning had extended into a period with more favorable drying conditions, such as from the summer through the winter months, the eventual loss in weight would have been greater.

For the walls of concrete and sand-lime bricks, the loss for more extended seasoning would apparently have been greater than for the walls of clay 
and shale bricks. Although the rate of loss of the piers inmediately before the fire test of the walls was low, further seasoning of the piers for 5 or more months resulted in weight losses from 30 to 70 percent of those sustained before the time of the fire test. The average weight loss of the piers at the time of the compression test after aging an arerage of about 230 days was $6.2 \mathrm{lb} / \mathrm{ft},{ }^{3}$ or between 4 and 5 percent of the weight of the masonry. Hence, the indications are that if the concrete and sand-lime brick walls had been aged as long as the piers they would have had a further weight loss of 1 to 2 percent of their weight beyond that obtained at the time of the fire test.

\section{b. Small Walls}

These walls were built in a building within which ceramic furnaces were operated, with resulting good drying conditions for the walls. Furthermore, eight of the walls, after seasoning under room conditions for about 1 month, were placed within enclosures and dried to constant or near constant weight at a rerage temperatures in the range $160^{\circ}$ to $180^{\circ} \mathrm{F}$. On remoral from the enclosure they would gain in weight under room atmospheric conditions.

\section{Testing Equipment and Methods}

\subsection{Panel Frames}

The large walls were built into frames constructed of 20 -in. steel girder beams, the parts thereof exposed to fire or heat as placed for the fire test being protected with concrete. They were supported on trollers running on the lower flange of orerhead beams. The computed strength of the frames as stressed by the expansion or loading of the wall under test ranged from 340,000 to 400,000 lb. Although the highest load applied to the walls did not exceed $240,000 \mathrm{lb}$, the loads induced by expansion of the wall as exposed to fire might be greater. 'To strengthen the frames into which the leavier walls were built and to secure a greater degree of restraint on the wall, members made of two 8-in. ehannels spanning the height of the frarne and bolted to webs of the top and bottom frarne members were placed one on each side of the vertical center line of the panel.

The frames for the small walls were built of reinforced concrete or protected steel. For the frames in which the walls were tested under load, the top member was free from the side members and served to transmit and distribute the load over the wall.

\subsection{Furnace Equipment}

The furnace, a section of which is shown in figure 3 , was used in fire tests of almost all of the large walls. It was fired with fuel oil of specific gravity 0.87 to 0.93 , gas not being available at the

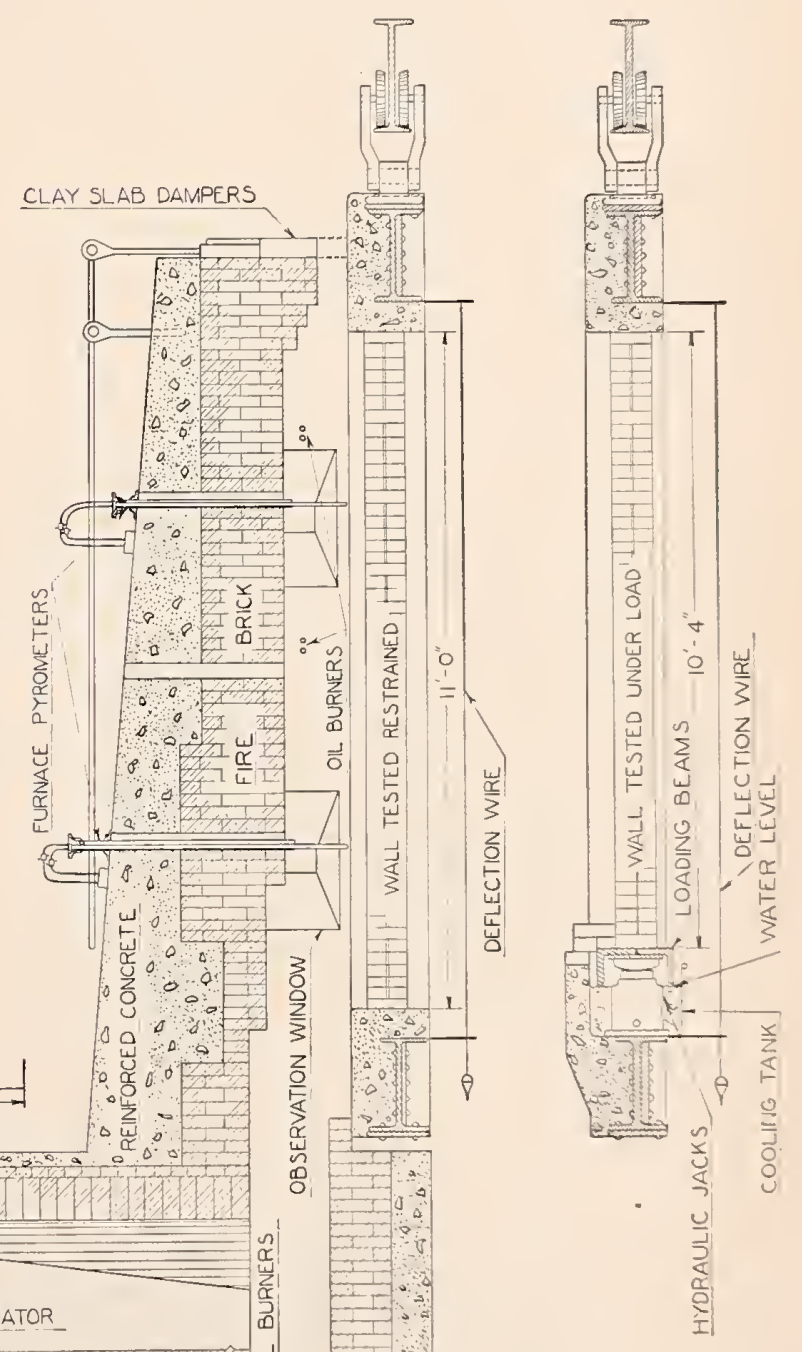

FigURE 3. Section through large testing furnace.

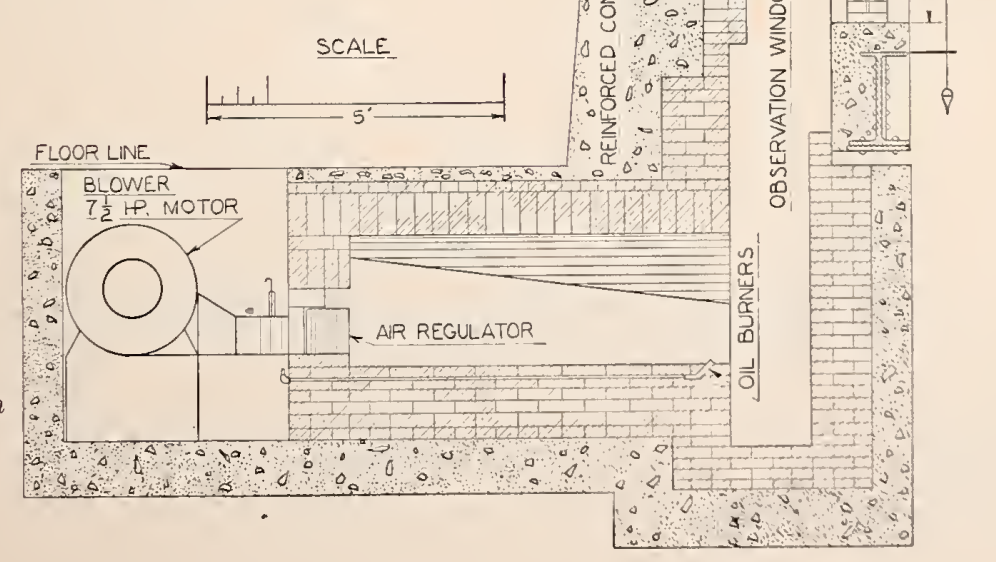


site. The oil was dispersed with jets of air at 20to $25-\mathrm{lb} / \mathrm{in}^{2}{ }^{2}$ pressure. Further air for combustion and for forcing flame and heated air over the exposed side of the test wall was supplied by a blower fan at the back of the burner chamber.

Originally, there were two main burners, which later were increased to four. Four auxiliary burners were also added, two on each side, one near the midheight of the panel, and the other about $3 \mathrm{ft}$ higher.

The last tests in the series, Nos. 7, 70, 71, and 72 , were made in a gas-fired furnace of design similar to that shown in figure 3 , descriptions of which are given in BMS71, BMS117, and BMS120 [2, 3, 4].

The tests of the small walls were conducted in a gas-fired furnace having four blast burners on each side projecting flame at a small angle on the back wall of the chamber, which curved outward toward the center of the test wall. Auxiliary inlets on each side supplied the additional compressed air required for combustion. A view of this furnace is given in figure 9 of RP37 [1].

\subsection{Loading and Restraint}

The large walls tested under working load were supported on two heavy channels about $8 \mathrm{ft}$ long, under each of which were placed two 200-ton hydraulic jacks resting on the lower member of the panel frame. The jacks were actuated by oil under pressure from a motor-driven pump. The oil pressures, which seldom exceeded 1,000 lb/in. ${ }^{2}$, were measured with gages and a fluid-pressure scale. Load on the small walls was applied with a hydraulic jack bearing against an overhead member secured at its ends to the bottom member of the panel frame.

The walls tested restrained were built solidly into the panel frames. The restraint was relieved to the extent that the panel frame members deflected under pressure from the expanding wall and also from the deflection of the members due to uneven heating. The measurements made on the frames for the large walls indicated that at the midpoint the top member deflected upward during test in the range $1 / 4$ to $1 \mathrm{in}$., and the bottom member deflected similarly downward. The sicle members deflected inward by smaller amounts where there was clearance between them and the test wall. The greater part of these deflections was apparently due to temperature effects on the panel members.

A number of the large 8- or 12-in.-thick walls were built clear of the panel frame at the top and sides, thus allowing them to deflect freely because of the temperature difference between their fireexposed and unexposed sides. To prevent undue curvature at the top of the 8-in. walls, an 8- by 8 -in. pilaster was built into them at each end on the unexposed side.

\subsection{Furnace Fire Exposure}

\section{a. Furnace Control Curve}

At the time these fire stests were begun, the control of furnace temperatures had been standardized to call for an average of $1,550^{\circ} \mathrm{F}\left(843^{\circ} \mathrm{C}\right)$ at the end of $1 / 2 \mathrm{hr}, 1,700^{\circ} \mathrm{F}\left(927^{\circ} \mathrm{C}\right)$ at $1 \mathrm{hr}$, and $1,850^{\circ} \mathrm{F}\left(1,010^{\circ} \mathrm{C}\right)$ at $1 \frac{1}{2} \mathrm{hr}$. Subsequent to this, the rise was constant at $75 \mathrm{deg} \mathrm{F}$ per hour, the temperature for the 4 -hr point being $2,000^{\circ} \mathrm{F}$ $\left(1,093^{\circ} \mathrm{C}\right)$, and $2,300^{\circ} \mathrm{F}\left(1,260^{\circ} \mathrm{C}\right)$ at $8 \mathrm{hr}$.

In the tests carried beyond $8 \mathrm{hr}$, it was the intention to continue raising the furnace temperature $75 \mathrm{deg} \mathrm{F}$ per hour until $2,500^{\circ} \mathrm{F}$ was reached at $10 \mathrm{hr} 40 \mathrm{~min}$, after which it was to be maintained at this level. According to a later revision of the standard, the temperature of $2,300^{\circ} \mathrm{F}$ at $8 \mathrm{hr}$ is to be maintained for longer test durations. These furnace reference curves are shown in dashed lines on the time-temperature plots.

\section{b. Pyrometer Mounting}

The furnace pyrometer mounting initially used is shown in figure 4 , the thermocouple wires being in pairs of chromel and alumel. On account of the high cost and frequent breakage with this type of mounting, $1 / 2$-in. black-iron pipes were later substituted, capped or welded closed at the furnace end. Thermoelectric properties of chromel-alumel wire are not affected by black iron even at the temperature of the furnace, and it was also found that the lag and radiation effects on the temperature readings are about the same as for the procelain-tube mounting.

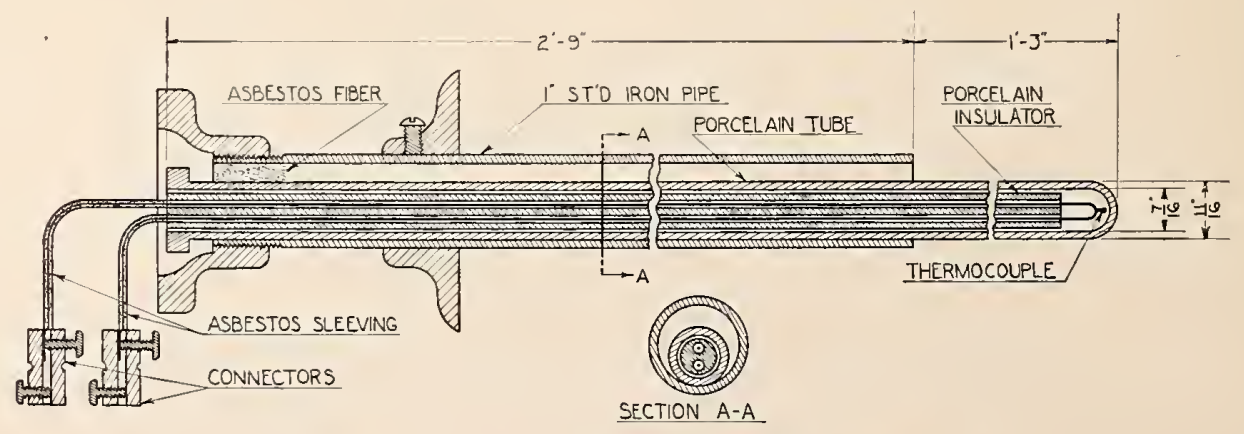

Figure 4. Detail of furnace pyrometer mounting. 
In the tests with the furnace shown in figure 3, there were six furnace prrometers thus mounted, symmetricalls placed $3 \mathrm{ft}$ above and below the center line of the panel, two on the vertical center line, and two $5 \frac{1}{2} \mathrm{ft}$ from it on each side. The end of the mounting was kept at approximately 3 in. from the wall under test.

In the tests conducted in the small furnace, six pyrometer's with iron-pipe mountings were located in two vertical rows $1 \mathrm{ft}$ to the side of the center of the panel, with two on the horizontal center line, two $14 \mathrm{in}$. above and two below it, similarly placed.

\section{c. Lag and Radiation Effects}

Because of the insulating effect of the mounting [5], the thermocouple readings during the initial part of the test were far below the temperature of the furnace gases, and even at $5 \mathrm{~min}$ the lag was in the order of 150 to $250 \mathrm{deg}$ F. Howerer, at 20 to $30 \mathrm{~min}$, the lag effect was not appreciable.

The mounting was also cooled by radiation from furnace and test walls that were at lower temperatures than the furnace gases. During the first part of the test, this may affect the readings by as much as $300 \operatorname{deg} \mathrm{F}$, decreasing, as the furnace and test walls heat up, to the order of $100 \mathrm{deg} F$ at 4 or $5 \mathrm{hr}$.

The temperatures called for according to the furnace control curve are adjusted to allow for the lag and radiation effects that were incurred with the prescribed pyrometer mounting.

\section{d. Unprotected Furnace Thermocouples}

To obtain information on the temperature variation in the large furnace and some indications of lag and radiation effects on the readings of the mounted furnace thermocouples, nine unprotected thermocouples of No. 18 B\&S gage chromelalumel wire were placed with a 12-in. length in the furnace and the thermocouple junction about $1 \mathrm{in}$. from the fire-exposed face of the wall. They were located symmetrically with reference to the center of the panel, 3 on the horizontal center line and 3 distant $1 \frac{1}{2} \mathrm{ft}$ from its top, bottom, or side borders.

\subsection{Determination of Wall Temperatures}

Temperatures at the center of the thickness of 4- and 8-in. walls and between the wythes of 12-in. walls were determined with 5 chromelalumel thermocouples, the leads for $6 \mathrm{in}$. or more from the junction being placed parallel with the wall.

The temperatures of the unexposed face of the wall were obtained with iron-constantan or chromel-alumel thermocouples, the wire size ranging from No. 22 to No. $30 \mathrm{~B} \& \mathrm{~S}$ gage. The regular number for the large walls was 13 , of which 9 were located over the central onf-third of the area. They were in rose contact with the wall surface and frecly exposed. Other thermocouples were placed over holes or cracks that developed as the test progressed. In addition. 1 or 2 thermocouples on the face of the lower part of the wall were covered with $3 \frac{1}{2}$ in. of loose cotton in a $3-\mathrm{ft}$ square box or were in contact with the board face of a similar box filled with wood excelsior. This simulated conditions where clothing or bales or crates of combustible materials are in contact with the unexposed side.

After a number of the tests had been completed, the method of temperature measurement on the unexposed surface was standardized to require thermocouples or thermometers under asbestos pads 6 in. sq and 0.40 in. thick. [6] For some time prior and subsequent thereto, the determinations were thus made, although parallel determinations were made with uncovered thermocouples to obtain approximate correlation of readings.

The temperatures on the unexposed face of the small walls were determined with uncovered thermocouples and with thermocouples or thermometers under the 0.40 -in.-thick asbestos pads, generally 3 in number, located 1 at the center of the wall and the others about $1 \mathrm{ft}$ distant on a diagonal center line.

\subsection{Calibration of Thermocouples}

The temperature-emf relations of representative samples of the thermocouple wire were determined by comparison with a thermocouple for which this relation was known. Due to changed temperature-emf relations on reheating after use at high temperatures, the furnace thermocouples were replaced for each test except for those of short duration. Thermocouples in the walls werc also thus replaced if the temperatures indicated had been above certain limits.

\subsection{Deflection Measurements}

The deflections of the large walls were measured with reference to weighted wires suspended from the top member of the panel frame and passed through holes in pegs secured to the lower nember. Measurements were made at the center of the wall and at the quarter points of the height and width. For the walls tested unrestrained, deflections were also measured at the top center and top corners and at two intermediate points.

\subsection{Hose-Stream Tests}

Typical wall constructions were subjected to hose-stream tests after fire exposures of giren durations. The tests were conducted according to the ASTA or ASA fire-test stamedard applicable at the time. 'The stream was delivered through a National Standard playpipe having 1s-in. nozzlo diameter, the water pressure being obtained with a motor-driven centrifugal pump. 


\section{Program of Tests}

\subsection{Solid Walls}

Table 6 gives the schedule of fire-endurance tests of solid brick walls, the designs of which are shown in figure 1 ( $\mathrm{A}$ to $\mathrm{C}$ ) and in figure 2 . The schedule included 27 tests of large walls and about an equal number of the smaller size. They were tested either under working load, restrained within the panel frame, or in the unrestrained condition with a clearance of $1 / 2$ to $1 \frac{1}{2}$ in. from the sides and top of the frame.

Most of the walls were laid in mortar having $1: 1 \frac{114}{4}: 6$ or $1: 1 \frac{1}{2}: 6$, volume parts of portland cement, hydrated lime, and sand. These are equivalent, respectively, to about $1: 0.53: 5$ and $1: 0.64: 5$ parts by weight of dry materials. Two of the walls were laid up in portland cement and mortar, proportioned 1:3 by volume, and three in lime mortar proportioned $1 \frac{11 / 4}{1}: 3$ by volume. All but six were tested without plaster finish on either side.

TABLE 6. Description of solid brick walls for fire-endurance tests

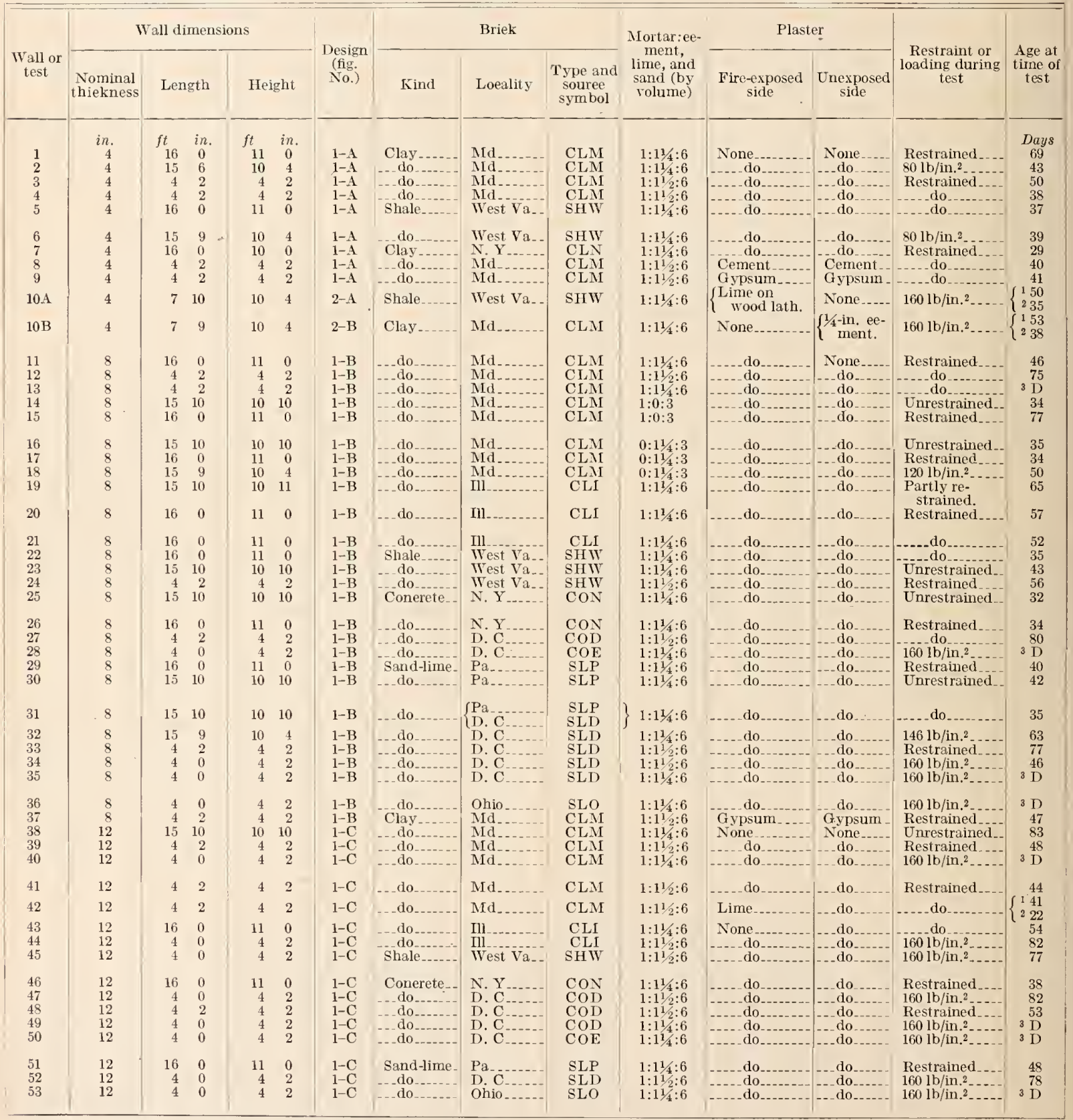

1 Masonry. 2 Plaster. 3 Dried to eonstant weight. 


\subsection{Walls of Hollow Design}

Table 7 gires the schedule of fire-endurance tests of walls having one or more cavities spanned br header bricks or wire ties, the designs of which are giren in figure 1 ( $\mathrm{D}$ to $\mathrm{L}$ ). They were all of clay or shale bricks laid up in portland-cementlime-sand mortar. The conditions of loading and restraint were the same as for the solid walls.

\subsection{Fire and Hose-Stream Tests}

Table 8 describes the walls which were subjerted to a hose-stream test after a fire-exposure of $1 \mathrm{hr}$ or after the fire-endurance test. Most of them were built in three or more sections bonded together and of bricks representative of those in the walls for the fire-endurance tests.

TABLE 7. Description of hollow walls for fire-endurance tests

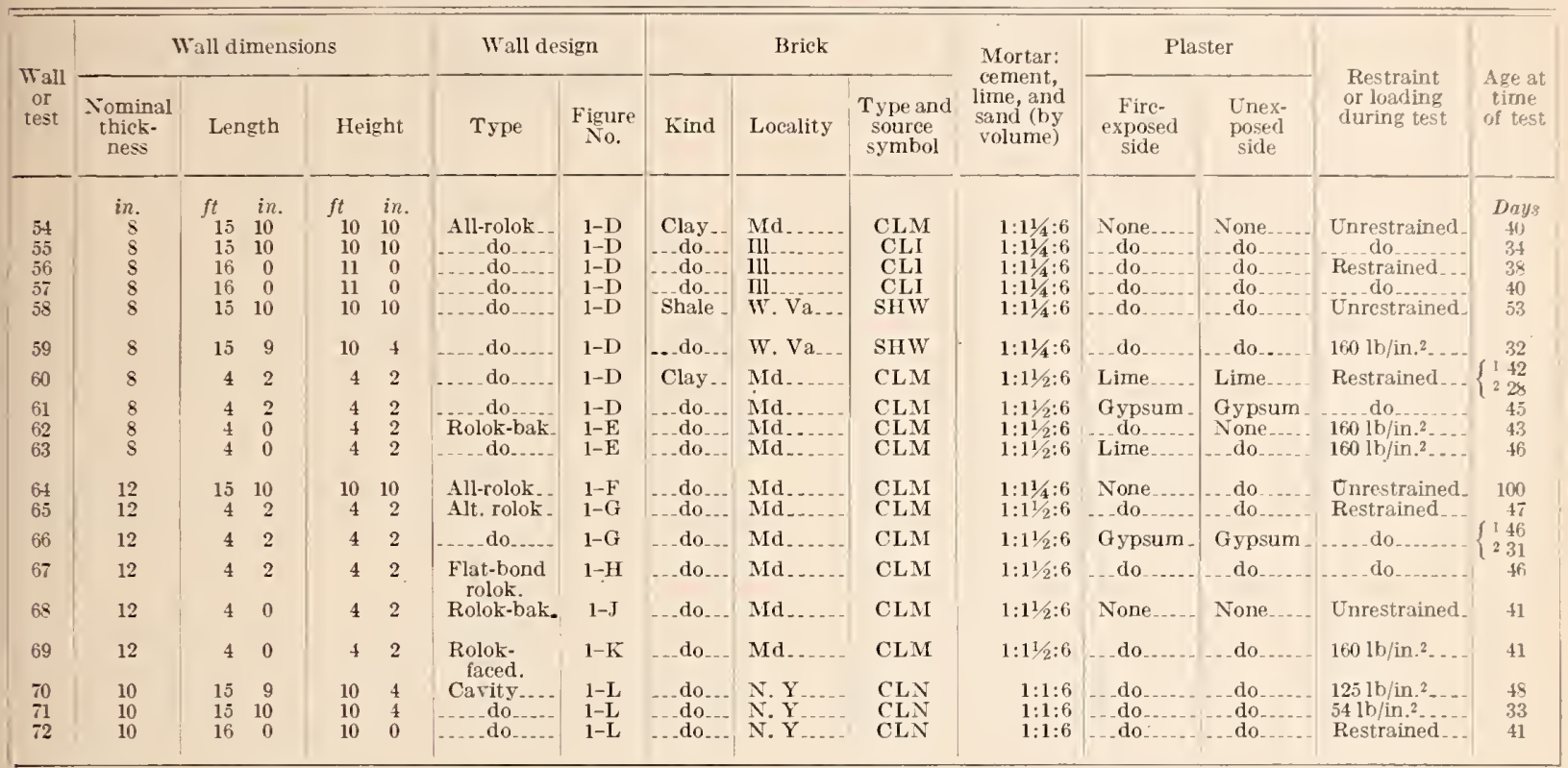

1 Masonry.

2 Plaster.

TABLE 8. Description of walls for fire and hose-stream tests

No plaster was applied on any of the walls subjected to the fire and hose stream test

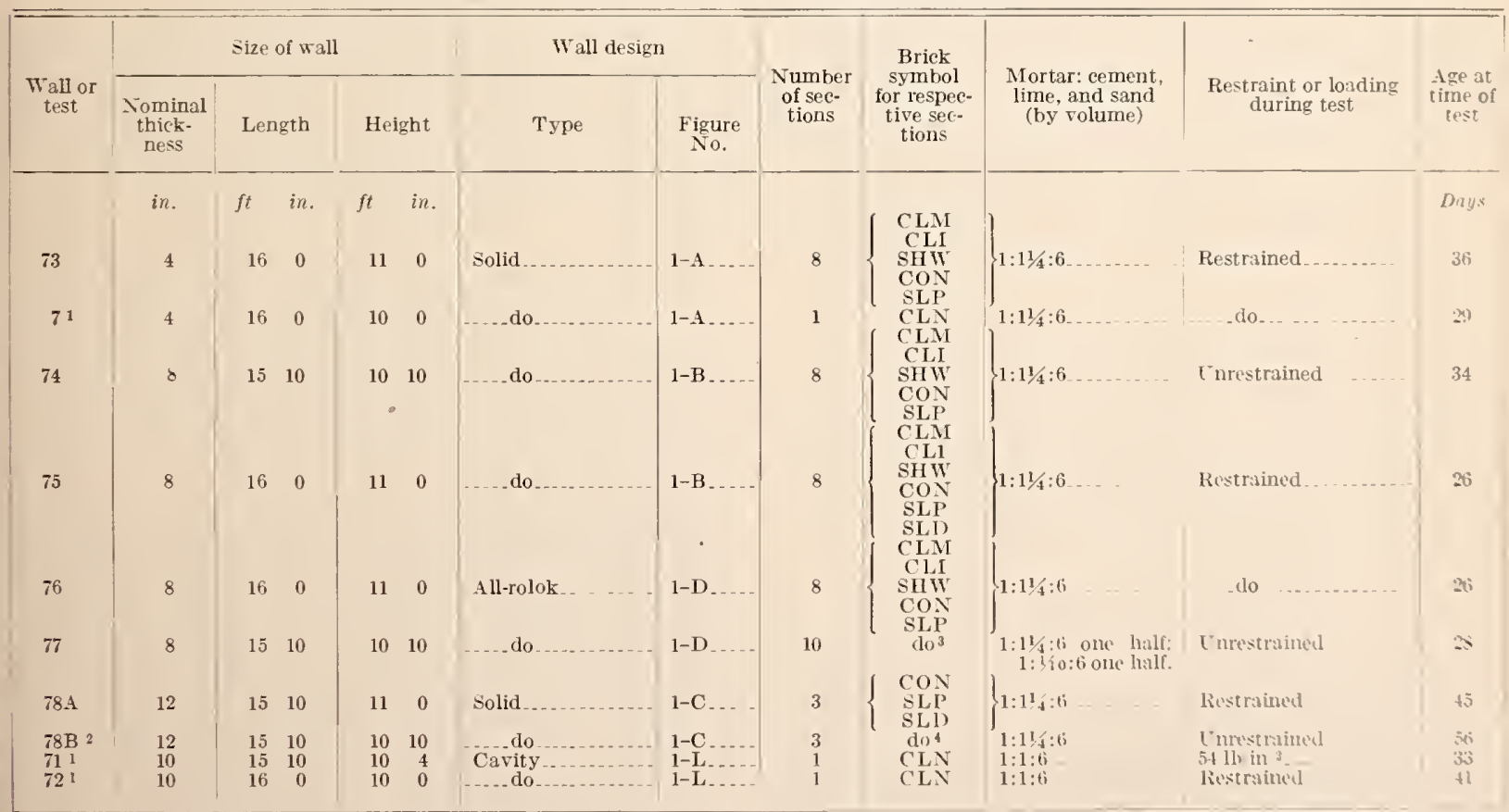

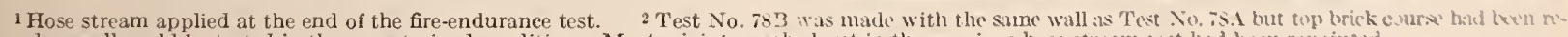
moved so wall could be tested in the unrestrained condition. Mortar joints washel out in the lurevious hose-stream test liad beeu rupuinted.

${ }^{3}$ Includes CLM, CLI, SHT, CON, SLP.

Include's CON, SLP, SLD. 


\section{Results of Fire-Endurance Tests}

\subsection{Criteria of Fire-Endurance Limit}

The results of the fire-endurance tests from the standpoint of limits of temperature rise on the unexposed surface and within the wall are given in the tables in sections 6.2 and 6.3. Also given is the time at which some of the walls exposed to fire under load failed under the working load applied, this being their fire-endurance limit in the absence of a lower limit based upon other criteria.

\section{a. Limits of Surface-Temperature Rise}

According to the test specifications cited [6] and later issues thereof, the permissible average limit of temperature rise on the unexposed surface above the initial is $250 \mathrm{deg} F$, and for a single location, $325 \operatorname{deg} \mathrm{F}$. This assumes that measurements are made under the prescribed asbestos pads. As previously indicated, in the earlier tests the greater number of temperature measurements were made on the freely exposed surface. A comparison of results where both methods were used indicate that the average limit of temperature rise under the asbestos pads is reached in about 0.84 of the time the limit is reached with the uncovered thermocouples. This agrees closely with results of similar comparisons reported and applied in a previous paper [1]. Accordingly, in the tables in sections 6.2 and 6.3 , for tests where the average limit of surface temperature rise was obtained only on the free-surface, the derived limit for determination under the asbestos pads, obtained by applying the above factor, is given in italics. It appears that results thus derived come well within the limits of variation due to difference in materials and bricks within groups for which the results are herein summarized in terms of average values.

Significant information is also obtained from the time hmits of temperature rise obtained under the large cotton pad and excelsior box applied on the unexposed surface in the earlier tests and also the limits indicated over cracks and imperfect joints.

\section{b. Temperature Rise Within the Wall}

The limits of temperature rise within the wall are given in the last double column of the tables in section 6.2 and 6.3. These are used as the basis for indicating fire-endurance limits of walls having combustible members framed into them for a 4 -in. depth from the unexposed side.

\section{c. Residual Temperature Rise}

Where the limit of temperature rise was reached after the fire was shut off, it is included in parenthesis in the tables, except where the lag is only a few minutes. Although not applied as a basis for fire-endurance limits, it is significant as indicating the degree of temperature rise after the end of the fire exposure, with the wall remaining in front of the furnace in the same position as during the test.

\section{d. Lateral Deflection}

Although the test specifications do not place a limit on lateral deflections, they determine to a large extent the ability to sustain load and the stability under fire exposure. Lateral deflections are largely due to temparature differences between the fire-exposed and unexposed surfaces of the wall.

The center deflection, $f$, for the restrained or loaded wall, free from the panel frame at the sides, can be expressed approximately by the following relation: [7]

$$
f=\frac{C h^{2}\left(T_{2}-T_{1}\right)}{8 t},
$$

where $C$ is a constant involving the coefficient of expansion of the wall material, $h$ is height, $t$ the wall thickness, and $\left(T^{2}-T^{1}\right)$ the temperature difference between the fire-exposed and unexposed sides of the wall.

Based upon the same considerations, the deflection at the top of unrestrained walls will be four times the center deflection for the restrained or loaded condition.

\subsection{Results With Solid-Wall Constructions}

The solid-wall constructions in 4-, 8-, or 12-in. nominal thickness, for which results are given in table 9, were built of clay, shale, concrete, or sand-lime bricks.

\section{a. Walls of 4-in. Thickness}

The 4-in. walls were all of clay and shale bricks and were tested either under load or restrained within the panel frame. There was no failure under load or from excessive deflection before the time corresponding to their fire-endurance limit as determined by temperature rise on the unexposed surface.

(1) Temperature-rise limits. The temperature rise of $250 \mathrm{deg} F$ was reached in an average time of $1 \mathrm{hr} 21 \mathrm{~min}$ for the unplastered walls as referenced to temperatures under the asbestos pads. A $5 / 8$-in. thickness of portland cement or gypsum plaster on both side (tests 8 and 9) increased the fire-endurance by 1 to $1 \frac{11}{2} \mathrm{hr}$.

One wall tested in two sections, $10 \mathrm{~A}$ and $10 \mathrm{~B}$, was stiffened with pilasters (fig. 2). Lime plaster on wood lath was applied over the pilasters on the fire-exposed side of $10 \mathrm{~A}$ and a $1 / 4-i n$. thickness of portland-cement plaster on the unexposed side of 10B. Although the pilasters decreased the maximum center deflections to $1 / 2$ in., the plaster finish added little to the fire-endurance periods.

(2) Time-temperature curves. The temperature curves for tests of 4 -in. walls are given in figures 5,6 , and 7 . The curves marked $\mathrm{F}$ give the temperatures indicated by the furnace pyrometers 
mounted as shown in figure 4 . For test 5 , the curves marked 1 give the average, maximum, and minimum temperatures indicated by 9 unprotected furnace thermocouples of No. 18 gage wires placed with junctions about 1 in. from the fireexposed face of the wall.

The curres marked $\mathrm{P}$ give the temperatures under the standard 6- by 6 - by 0.4 -in. asbestos pads placed against the unexposed face of the wall, and those marked $S$, the temperatures indicated by thermocouples in close contact with the unexposed face but freely exposed. Other curves give temperatures under the 3 - by 3 -ft pads or boxes filled with cotton or excelsior applied to the unexposed side of the walls in some of the earlier tests and shown in place in figure 8 .

The arrows on the curves of temperature on the unexposed side indicate the time when an average temperature rise limit of $250 \mathrm{deg} \mathrm{F}$, or a rise at any thermocouple location of $325 \mathrm{deg} \mathrm{F}$, is reached, whichever in any given test occurs earlier.

(3) Lateral deflections. Typical deflection curves for tests of 4 -in. walls are given in figure 9 . For walls made of bricks from the same source, the deflections of those tested restrained were greater than for tests under load, the highest deflection being obtained with a restrained shale-brick wall. Figure 10 shows the unexposed side of a 4-in. clar-brick wall after a fire-endurance test of $1 \mathrm{hr}$ $25 \mathrm{~min}$, followed by hose-stream application on the fire-exposed side. The maximum deflection of 6 in. during the fire exposure was decreased to no more than $3 \mathrm{in}$. from the cooling effect of the hose stream.

\section{b. Clay-and Shale-Brick Walls of 8-in. Thickness}

The details of construction and main results of tests for solid 8-in. walls built of clay or shale bricks in the group 11 to 24 and plastered wall 37 are given in tables 6 and 9 . Wall 18, laid up in lime mortar, was tested under load, the rest being tested restrained within the panel frame or built free from the frame at sides and top for test in the unrestrained condition.

(1) Surface-temperature limits. Most of the present tests are within the group of large walls in which the fire exposure was limited to $6 \mathrm{hr}$, on the ground that in regulations such as building codes no higher fire resistance is required. In fact, the maximum required does not generally exceed $4 \mathrm{hr}$.

With the 6-hr test limit and temperatures on the unexposed side determined on the free surface, the limit of $250 \mathrm{deg}$ average rise was attained only in test 19 . However, significant information was obtained from the times at which the temperaturerise limits occurred under the large cotton pad, excelsior box, and at cracks (see fig. 11). Also, in test No. 12 (fig. 12) the rise limit was determined with thermometers under the standard asbestos pads.
Based on the results of these determinations and with allowance for the methods used, the average fire-endurance limit of 8 -in. walls built of clay or shale bricks and normally seasonerl, was indicated as being near $5 \mathrm{hr}$. With gypsum plaster on both sides (test 37 ), the limit of surface temperature rise was not reached until after $9 \mathrm{hr}$. Although the increment in fire endurance due to plaster increases with wall thickness, in this case, the plastered wall apparently had not attained the degree of dryness of unplastered walls at the time of testing. 'The lag in temperature rise is shown by the temperature curves in figure 13.

(2) Wall-temperature limits. The permissible temperature rise within the wall, $4 \mathrm{in}$. from the unexposed surface, was reached in an arerage time of $2 \mathrm{hr} 16 \mathrm{~min}$ for the 12 normally seasoned walls. The average of the six lowest results was $2 \mathrm{hr}$.

(3) Effect of drying at elevated temperatures. Wall 13 was dried to constant weight at temperatures in the range $160^{\circ}$ to $180^{\circ} \mathrm{F}$. The $325-\mathrm{deg}-\mathrm{F}$ average temperature rise was reached in the wall $4 \mathrm{in}$. from the unexposed surface at $2 \mathrm{hr} 1 \mathrm{~min}$ and an average rise of $250 \mathrm{deg} F$ on the unexposed surface under the asbestos pads at $4 \mathrm{hr} 9 \mathrm{~min}$. The latter compares with $5 \mathrm{hr} 11 \mathrm{~min}$ for the companion wall 12, aged under room conditions. Because wall 13 gained in weight under dry heated-room conditions after removal from the drying chamber, it was apparently in a drier condition than walls would usually be after extended aging in heated buildings.

(4) Loading, restraint, and lateral deflection. Wall 18, laid up in lime mortar, was tested under load of $120 \mathrm{lb} / \mathrm{in}^{2}$, which was sustained throughout a fire test terminated at $6 \mathrm{hr}$. The original compressive strength of the masonry was 650 lb/in. ${ }^{2}$ The maximum lateral deflection was about 1 in. (fig. 9). No further fire tests under load were made of 8 -in. solid walls of clay or shale bricks because it was apparent that the load would be sustained.

For walls of brick from the same source (CL.M) as the loaded wall and tested restrained within the panel frame, No. 17 laid up in lime mortar deflected about $1 \mathrm{in}$. and walls 11 and 15 , laid up in cement-lime or cement mortar, near "2 in. The maximum deflection of walls of clay bricks from the other source, CLI, (tests $19,20,21$ and of shale bricks, SHIT (test 22) and tested restrained, were in the range $2 \frac{1}{2}$ to $t \mathrm{in}$. (tig. 9).

The maximum deflection at the top of the walls tested unrestrained (Nos. 14, 16, and 23. fig. ?) was on the average a little less than four times the center deflection for comparable restrained or loaded walls, which is in fair acreement with the relation derived from theory [7].

There was no collapse from exeessive deflection of restrained or unrestrained S-in. Walls of clay and shale bricks as tested on 11-ft heiglit for ti hi: which is beyond their fire condurance as limited by 
TABLE 9. Results of fire-endurance tests of solid walls of clay, shale, concrete, or sand-lime bricks

Walls having minimum lateral dimensions of $10 \mathrm{ft}$ and area of $100 \mathrm{ft}^{2}$ conform to present requirements of ASTM Standard E119

\begin{tabular}{|c|c|c|c|c|c|c|c|c|c|c|c|}
\hline \multirow{2}{*}{$\begin{array}{c}\text { Wall } \\
\text { or test }\end{array}$} & \multirow{2}{*}{$\begin{array}{l}\text { Nominal } \\
\text { thickness }\end{array}$} & \multirow{2}{*}{$\begin{array}{l}\text { Wall } \\
\text { area }\end{array}$} & \multirow{2}{*}{$\begin{array}{c}\text { Brick } \\
\text { symbol }\end{array}$} & \multicolumn{2}{|c|}{ Plaster } & \multirow{2}{*}{$\begin{array}{l}\text { Restraint or load- } \\
\text { ing during test }\end{array}$} & \multirow{2}{*}{$\begin{array}{l}\text { Age at } \\
\text { time } \\
\text { of test }\end{array}$} & \multicolumn{3}{|c|}{ Test duration } & \multirow{2}{*}{$\begin{array}{l}\text { Severity } \\
\text { of furnace } \\
\text { exposure }\end{array}$} \\
\hline & & & & Fire-exposed & Unexposed & & & Tim & & Why ended & \\
\hline $\begin{array}{l}1 \\
2 \\
3 \\
4 \\
5\end{array}$ & $\begin{array}{r}\text { in. } \\
4 \\
4 \\
4 \\
4 \\
4\end{array}$ & $\begin{array}{c}f t^{2} \\
176 \\
160 \\
17.4 \\
17.4 \\
176\end{array}$ & $\begin{array}{l}\text { CLM } \\
\text { CLM } \\
\text { CLM } \\
\text { CLM } \\
\text { SHW }\end{array}$ & $\begin{array}{l}\text { None } \\
\text { No................. }\end{array}$ & $\begin{array}{l}\text { None..... } \\
\text { No do }\end{array}$ & $\begin{array}{l}\text { Restrained } \\
80 \text { lb/in.2. } \\
\text { Restrained... } \\
\end{array}$ & $\begin{array}{c}\text { Days } \\
69 \\
43 \\
50 \\
38 \\
37\end{array}$ & $\begin{array}{rr}h r & n \\
6 & \\
2 & 2 \\
1 & 1 \\
0 & 4 \\
2 & 4\end{array}$ & $\begin{array}{l}\min \\
1 \\
20 \\
10 \\
45 \\
41\end{array}$ & $\begin{array}{l}\text { Set limit } \\
\text { High wall temp } \\
\text { do-... } \\
\text { Set limit } \\
\text { Deflection. }\end{array}$ & $\begin{array}{r}\text { Percent } \\
98.7 \\
100.4 \\
100.1 \\
98.0 \\
99.8\end{array}$ \\
\hline $\begin{array}{c}6 \\
7 \\
8 \\
9 \\
10 \mathrm{~A} \\
10 \mathrm{~B}\end{array}$ & $\begin{array}{r}4 \\
4 \\
4 \\
4 \\
14 \\
24\end{array}$ & $\begin{array}{l}163 \\
160 \\
17.4 \\
17.4 \\
81 \\
80\end{array}$ & $\begin{array}{l}\text { SHW } \\
\text { CLN } \\
\text { CLM } \\
\text { CLM } \\
\text { SHW } \\
\text { CLM }\end{array}$ & $\begin{array}{l}\text { do } \\
\text { Cement } \\
\text { Gypsum } \\
\text { Lime on wood lath } \\
\text { None. }\end{array}$ & $\begin{array}{l}\text { do do } \\
\text { Gypsumt } \\
\text { None............. } \\
\text { 1/4 in. cement. }\end{array}$ & $\begin{array}{c}80 \mathrm{lb} / \mathrm{in}^{2}{ }^{2} \\
\text { Restrained }\end{array}$ & $\begin{array}{l}39 \\
29 \\
40 \\
41 \\
50 \\
53\end{array}$ & $\begin{array}{ll}1 & 4 \\
1 & 2 \\
4 & \\
4 & \\
2 & 3 \\
2 & 3\end{array}$ & $\begin{array}{r}44 \\
25 \\
9 \\
1 \\
30 \\
30\end{array}$ & $\begin{array}{l}\text { Load failure..... } \\
\text { High wall temp. }\end{array}$ & \begin{tabular}{r|}
100.6 \\
100.5 \\
98.8 \\
98.7 \\
101.7 \\
101.7
\end{tabular} \\
\hline $\begin{array}{l}11 \\
12 \\
13 \\
14 \\
15\end{array}$ & $\begin{array}{l}8 \\
8 \\
8 \\
8 \\
8\end{array}$ & $\begin{array}{l}176 \\
17.4 \\
17.4 \\
171 \\
176\end{array}$ & $\begin{array}{l}\text { CLM } \\
\text { CLM } \\
\text { CLM } \\
\text { CLM } \\
\text { CLM }\end{array}$ & 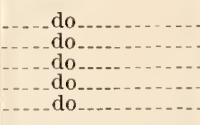 & $\begin{array}{l}\text { None-.... } \\
\text { do do..- } \\
\end{array}$ & $\begin{array}{l}\text { Restrained } \\
\text { Unrestrained } \\
\text { Restrained }\end{array}$ & $\begin{array}{l}46 \\
75 \\
D^{3} \\
34 \\
77\end{array}$ & $\begin{array}{ll}6 & \\
5 & 1 \\
4 & 0 \\
6 & 0 \\
6 & 0\end{array}$ & $\begin{array}{c}1 \\
10 \\
09 \\
01 \\
03\end{array}$ & $\begin{array}{l}\text { Set limit } \\
\text { High wall temp. } \\
\text { Set lo_mit }\end{array}$ & $\begin{array}{l}99.5 \\
98.8 \\
99.4 \\
97.5 \\
99.1\end{array}$ \\
\hline $\begin{array}{l}16 \\
17 \\
18 \\
19 \\
20\end{array}$ & $\begin{array}{l}8 \\
8 \\
8 \\
8 \\
8\end{array}$ & $\begin{array}{l}171 \\
176 \\
163 \\
173 \\
176\end{array}$ & $\begin{array}{l}\text { CLM } \\
\text { CLM } \\
\text { CLM } \\
\text { CLI } \\
\text { CLI }\end{array}$ & 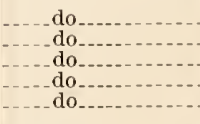 & \begin{tabular}{l} 
do do \\
\hdashline do \\
\hdashline do \\
\hdashline
\end{tabular} & $\begin{array}{l}\text { Unrestrained. } \\
\text { Restrained... } \\
\text { 160 lb/in.2. } \\
\text { Partly restrained. } \\
\text { Restrained...... }\end{array}$ & $\begin{array}{l}35 \\
34 \\
50 \\
65 \\
57\end{array}$ & $\begin{array}{l}6 \\
6 \\
6 \\
6 \\
6\end{array}$ & $\begin{array}{l}1 \\
0 \\
0 \\
2 \\
1\end{array}$ & 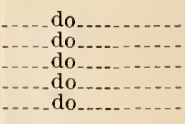 & $\begin{array}{r}99.0 \\
100.2 \\
98.3 \\
100.5 \\
99.3\end{array}$ \\
\hline $\begin{array}{l}21 \\
22 \\
23 \\
24 \\
25\end{array}$ & $\begin{array}{l}8 \\
8 \\
8 \\
8 \\
8\end{array}$ & $\begin{array}{l}176 \\
176 \\
171 \\
17.4 \\
171\end{array}$ & $\begin{array}{l}\text { CLI } \\
\text { SHW } \\
\text { SHW } \\
\text { SHW } \\
\text { CON }\end{array}$ & 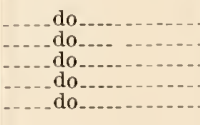 & \begin{tabular}{l} 
_. do \\
\hdashline \\
\hdashline
\end{tabular} & $\begin{array}{l}\text { do do } \\
\text { Unrestrained } \\
\text { Restrained } \\
\text { Unrestrained .... }\end{array}$ & $\begin{array}{l}52 \\
35 \\
43 \\
56 \\
32\end{array}$ & $\begin{array}{l}6 \\
6 \\
6 \\
4 \\
6 \\
6\end{array}$ & $\begin{array}{l}2 \\
1 \\
1 \\
0 \\
1\end{array}$ & \begin{tabular}{l}
- \\
- do do do \\
\hdashline do
\end{tabular} & $\begin{array}{r}97.5 \\
99.6 \\
100.8 \\
98.8 \\
100.2\end{array}$ \\
\hline $\begin{array}{l}26 \\
27 \\
28 \\
29 \\
30\end{array}$ & $\begin{array}{l}8 \\
8 \\
8 \\
8 \\
8\end{array}$ & $\begin{array}{l}176 \\
17.4 \\
16.7 \\
176 \\
171\end{array}$ & $\begin{array}{l}\text { CON } \\
\text { COD } \\
\text { COE } \\
\text { SLP } \\
\text { SLP }\end{array}$ & 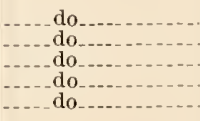 & 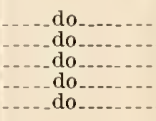 & $\begin{array}{l}\text { Restrained } \\
\text { do } \\
160 \mathrm{lb} / \mathrm{in} .^{2} \\
\text { Restrained } \\
\text { Unrestrained... }\end{array}$ & $\begin{array}{l}34 \\
80 \\
D^{3} \\
40 \\
42\end{array}$ & $\begin{array}{l}6 \\
7 \\
6 \\
6 \\
6\end{array}$ & $\begin{array}{r}2 \\
0 \\
17 \\
1 \\
1\end{array}$ & 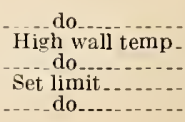 & $\begin{array}{r}99.0 \\
98.7 \\
99.8 \\
99.1 \\
100.8\end{array}$ \\
\hline 31 & 8 & 171 & $\left\{\begin{array}{l}\text { SLP } \\
\text { SLD }\end{array}\right.$ & \} & .... do.... & _..... do & 35 & 6 & 1 & .....do_.... & 99.9 \\
\hline $\begin{array}{l}32 \\
33 \\
34 \\
35\end{array}$ & $\begin{array}{l}8 \\
8 \\
8 \\
8\end{array}$ & $\begin{array}{c}163 \\
17.4 \\
16.7 \\
16.7\end{array}$ & $\begin{array}{l}\text { SLD } \\
\text { SLD } \\
\text { SLD } \\
\text { SLD }\end{array}$ & $\begin{array}{l}\text { do do..... } \\
\end{array}$ & $\begin{array}{l}\text { _. do } \\
\text { _o do }\end{array}$ & $\begin{array}{l}146 \mathrm{lb} / \mathrm{in} .{ }^{2} \\
\text { Restrained } \\
160 \mathrm{lb} / \mathrm{in} .^{2}\end{array}$ & $\begin{array}{l}63 \\
77 \\
46 \\
D^{3}\end{array}$ & $\begin{array}{r}6 \\
10 \\
8 \\
7\end{array}$ & $\begin{array}{r}0 \\
6 \\
0 \\
45\end{array}$ & $\begin{array}{l}\text { do } \\
\text { Het wall temp. } \\
\text { High wall temp. }\end{array}$ & $\begin{array}{l}98.2 \\
98.3 \\
97.4 \\
98.2\end{array}$ \\
\hline $\begin{array}{l}36 \\
37 \\
38 \\
39 \\
40\end{array}$ & $\begin{array}{r}8 \\
8 \\
12 \\
12 \\
12\end{array}$ & $\begin{array}{c}16.7 \\
17.4 \\
171 \\
17.4 \\
16.7\end{array}$ & $\begin{array}{l}\text { SLO } \\
\text { CLM } \\
\text { CLM } \\
\text { CLM } \\
\text { CLM }\end{array}$ & $\begin{array}{l}\text { Gypsum } \\
\text { None-_o } \\
\text { do }\end{array}$ & $\begin{array}{l}\text { Gypsum } \\
\text { None_... } \\
\end{array}$ & $\begin{array}{l}\text { Restrained } \\
\text { Unrestrained } \\
\text { Restrained } \\
160 \mathrm{lb} / \mathrm{in.}^{2} \\
\end{array}$ & $\begin{array}{l}\mathrm{D}^{3} \\
47 \\
83 \\
48 \\
\mathrm{D}^{3}\end{array}$ & $\begin{array}{r}6 \\
11 \\
5 \\
11 \\
10\end{array}$ & $\begin{array}{r}41 \\
2 \\
51 \\
36 \\
22\end{array}$ & $\begin{array}{l}\text { do do } \\
\text { Equip. failure } \\
\text { Set limit } \\
\text { High wall temp. }\end{array}$ & $\begin{array}{r}100.8 \\
100.2 \\
98.9 \\
101.6 \\
98.5\end{array}$ \\
\hline $\begin{array}{l}41 \\
42 \\
43 \\
44 \\
45\end{array}$ & $\begin{array}{l}12 \\
12 \\
12 \\
12 \\
12\end{array}$ & $\begin{array}{c}17.4 \\
17.4 \\
176 \\
16.7 \\
16.7\end{array}$ & $\begin{array}{l}\text { CLM } \\
\text { CLM } \\
\text { CLI } \\
\text { CLI } \\
\text { SHW }\end{array}$ & $\begin{array}{l}\text { Lime_do_................ } \\
\text { None_.... } \\
\end{array}$ & 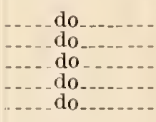 & $\begin{array}{l}\text { Restrained } \\
160 \mathrm{lb} / \mathrm{in} .^{2} \\
\end{array}$ & $\begin{array}{l}44 \\
41 \\
54 \\
82 \\
77\end{array}$ & $\begin{array}{r}8 \\
16 \\
6 \\
10 \\
12\end{array}$ & $\begin{array}{r}0 \\
5 \\
0 \\
21 \\
50\end{array}$ & $\begin{array}{l}\text { Set limit } \\
\text { High wall temp. } \\
\text { Set limit } \\
\text { Load failure... } \\
\text { High wall temp. }\end{array}$ & $\begin{array}{r}98.9 \\
105.2 \\
98.0 \\
100.1 \\
101.3\end{array}$ \\
\hline $\begin{array}{l}46 \\
47 \\
48 \\
49 \\
50\end{array}$ & $\begin{array}{l}12 \\
12 \\
12 \\
12 \\
12\end{array}$ & $\begin{array}{l}176 \\
16.7 \\
17.4 \\
16.7 \\
16.7\end{array}$ & $\begin{array}{l}\text { CON } \\
\text { COD } \\
\text { COD } \\
\text { COD } \\
\text { COE }\end{array}$ & $\begin{array}{l}\text { do } \\
\text { do } \\
\text { do....... } \\
\text { do }\end{array}$ & 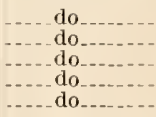 & $\begin{array}{l}\text { Restrained } \\
160 \mathrm{lb} / \mathrm{in}^{2} \\
\text { Restrained } \\
160 \mathrm{lb} / \mathrm{in} .^{2} \\
\end{array}$ & $\begin{array}{l}38 \\
82 \\
53 \\
D^{3} \\
D^{3}\end{array}$ & $\begin{array}{r}6 \\
16 \\
12 \\
13 \\
14\end{array}$ & $\begin{array}{r}1 \\
4 \\
30 \\
55 \\
0\end{array}$ & $\begin{array}{l}\text { Set limit } \\
\text { High wall teinp. } \\
\text { Set limit } \\
\text { High wall temp. } \\
\end{array}$ & $\begin{array}{r}98.8 \\
102.8 \\
100.6 \\
99.4 \\
101.3\end{array}$ \\
\hline $\begin{array}{l}51 \\
52 \\
53\end{array}$ & $\begin{array}{l}12 \\
12 \\
12\end{array}$ & $\begin{array}{l}176 \\
16.7 \\
16.7\end{array}$ & $\begin{array}{l}\text { SLP } \\
\text { SLD } \\
\text { SLO }\end{array}$ & \begin{tabular}{|c} 
_... do \\
\\
\end{tabular} & $\begin{array}{l}\text { do do....... } \\
\text { do }\end{array}$ & $\begin{array}{l}\text { Restrained } \\
160 \mathrm{lb} / \mathrm{in} .^{2}\end{array}$ & $\begin{array}{l}48 \\
78 \\
D^{3}\end{array}$ & $\begin{array}{r}6 \\
9 \\
13\end{array}$ & $\begin{array}{r}1 \\
57 \\
53\end{array}$ & $\begin{array}{l}\text { Set limit } \\
\text { Load failure... }\end{array}$ & $\begin{array}{r}98.5 \\
99.7 \\
101.0\end{array}$ \\
\hline
\end{tabular}

1 With pilasters. See figure $2, \mathrm{~A}$.

2 With pilasters. See figure $2, \mathrm{~B}$.

${ }^{3}$ Dried to constant weight at temperatures of $160^{\circ}$ to $180^{\circ} \mathrm{F}$.

temperature rise on the unexposed side. The unrestrained walls, all with 8 - by 8 -in. pilasters at the ends, deflected outward at the top up to 8 in., the pilasters serving to keep the top in approximate straight alinement (fig. 14).

(5) Effect of cracks and imperfect joints. The large walls were nearly all laid up by contract, and the workmanship as a whole was barely up to good construction practice. The filling and pointing of mortar joints on the surface of un- plastered walls apparently was not as well done as would be required on a construction job. Accordingly, steam and hot gases issued through small holes in the imperfect joints with temperatures over them higher than those on the adjacent surface.

Such higher temperatures also occurred over cracks formed during test. These cracks varied from very fine to those with openings of $1 / 4$ to $5 / 16$ in. The larger openings were generally at 
TABLE 9. Results of fire-endurance tests of solid walls of clay, shale, concrete, or sund-lime bricks-Corntinued

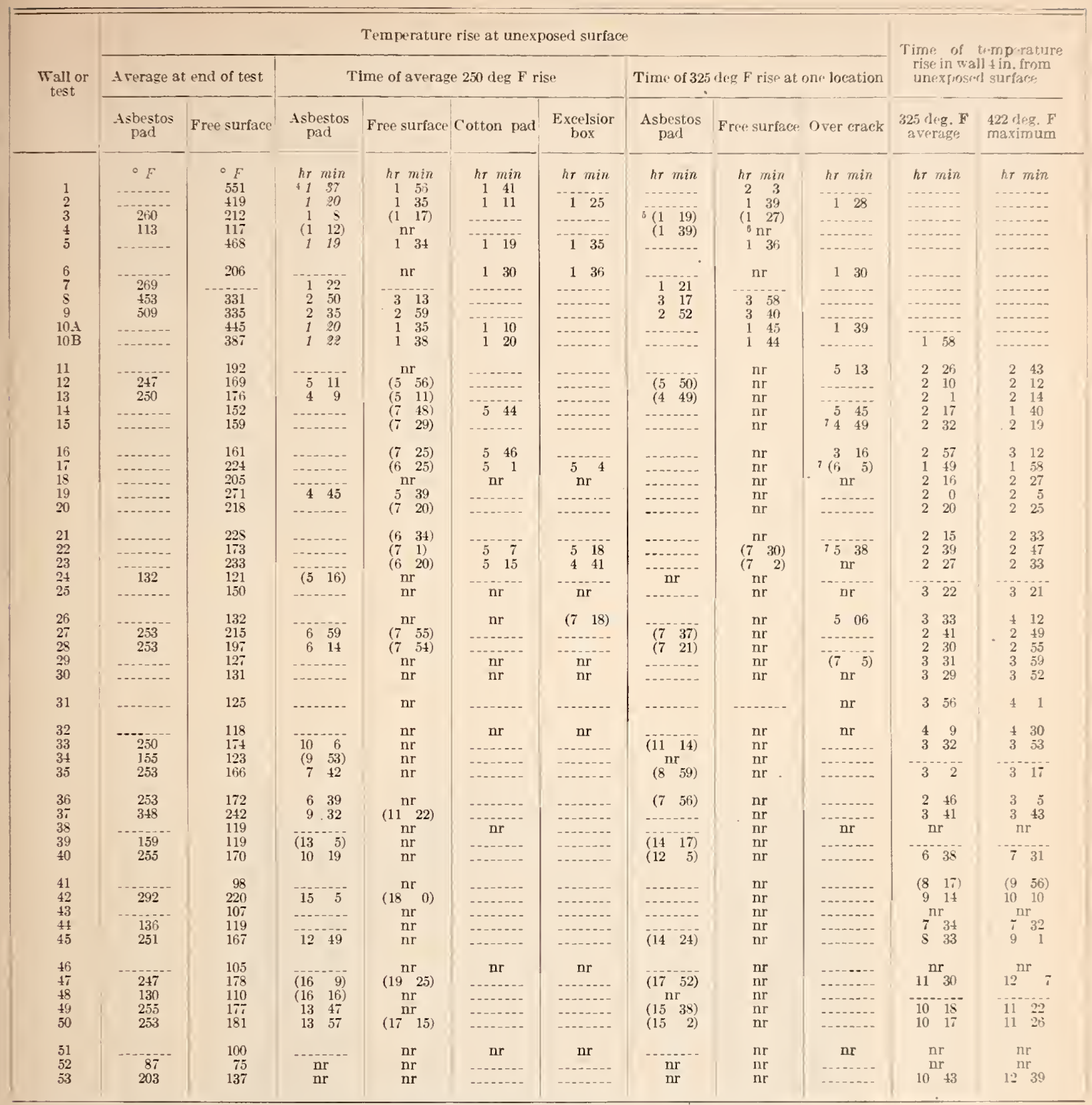

4 Figures in italics indicate derived temperature limit for determination under asbestos pads (see section $6.1,3$ ). 5 Figures in parentheses indicate temperature rise reached after the test fire was shut off.

" "nr" indicates that a given temperature was not reached.

7 Cotton waste placed over thermocouple.

the joints between bricks and not necessarily continuous through the wall. On the fire-exposed side, the cracks were relatively smaller.

The tme at which a temperature rise of $325 \mathrm{deg}$ $\mathrm{F}$ occurred over cracks is given in table 9 . This limit was reached before $5 \mathrm{hr}$ only in the tests of walls 15 and 16 . Wall 15 was laid up in portlandcement mortar and tested restrained. Due to mortar that did not adhere to the trowel and spread readily, the wall had a number of small holes, the high temperature rise occurring over one of them with a wad of cotton corcring the thermocouple.

For wall 16, laid up in lime mortar and tested unrestrained, the tempersture riso limit was reached at $3 \mathrm{hr} 16 \mathrm{~min}$ orer a laree diaconal crack in the upper part of the wall. For wall 17. tested restrained, and wall is under lond, both 


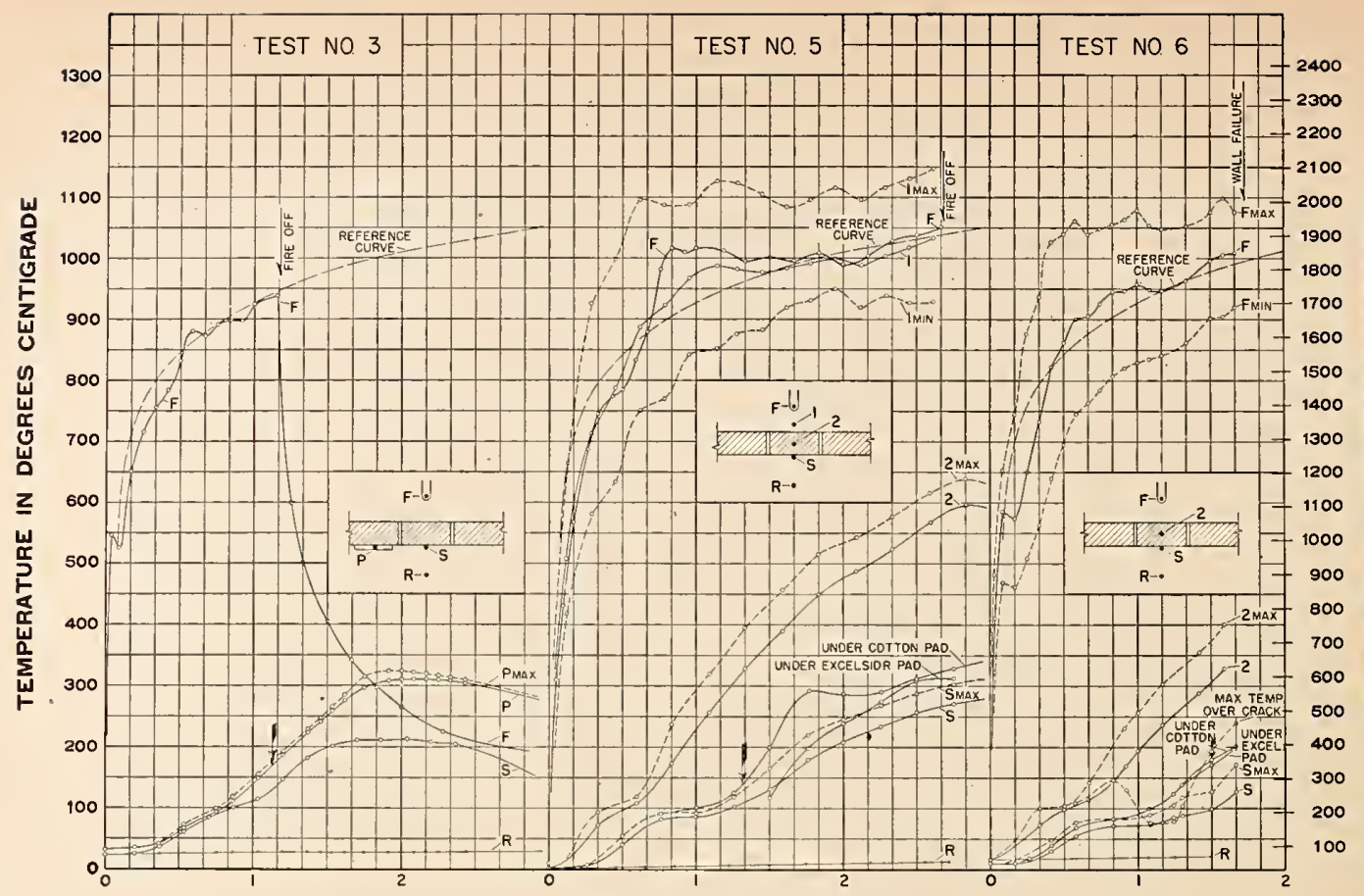

TIME IN HOURS

Figure 5. Temperatures in fire-endurance tests of 4-in. unplastered walls 3,5 , and 6 .

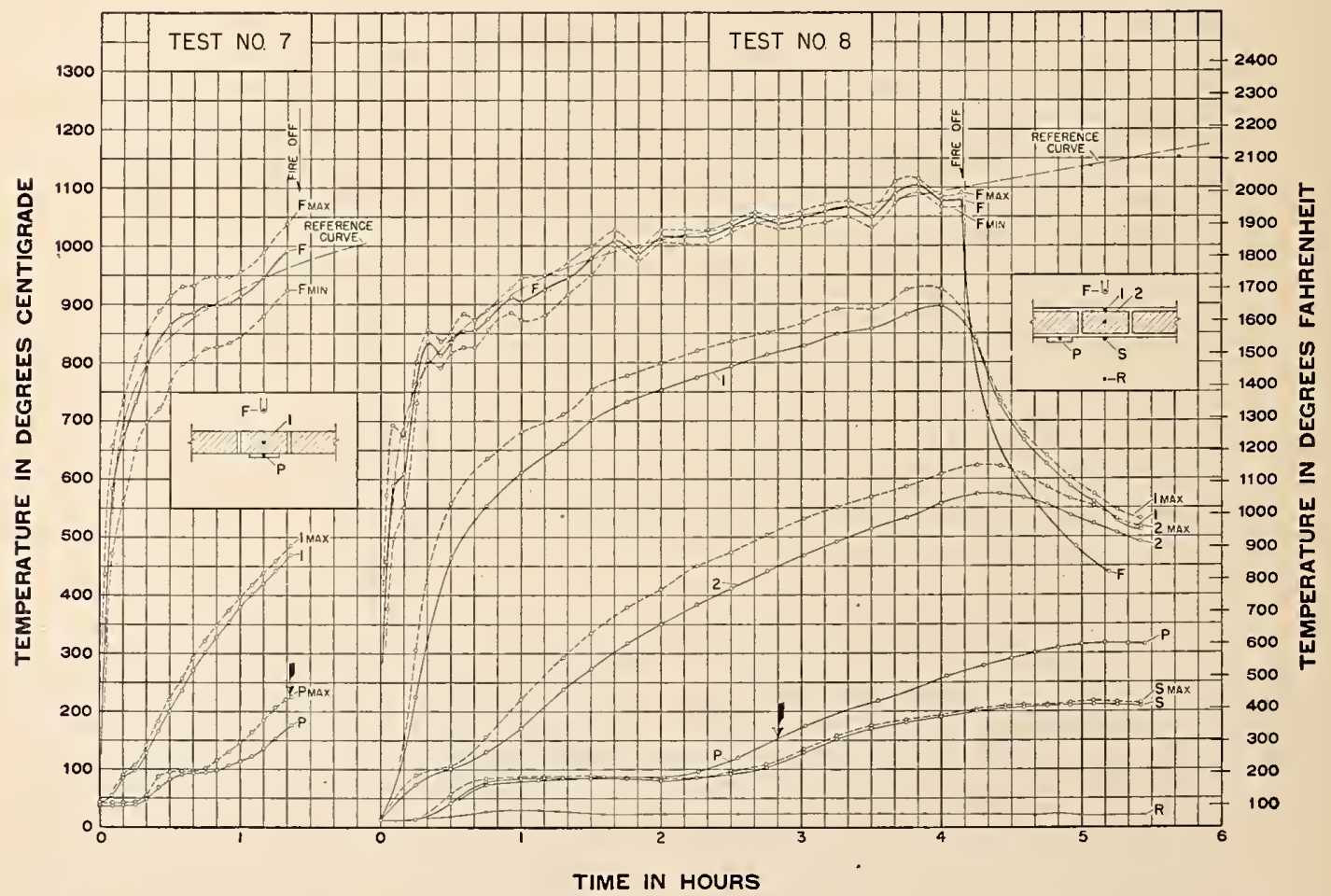

Figure 6. Temperatures in fire-endurance tests of 4 -in. unplastered wall 7 , and 4-in. plastered wall 8. 


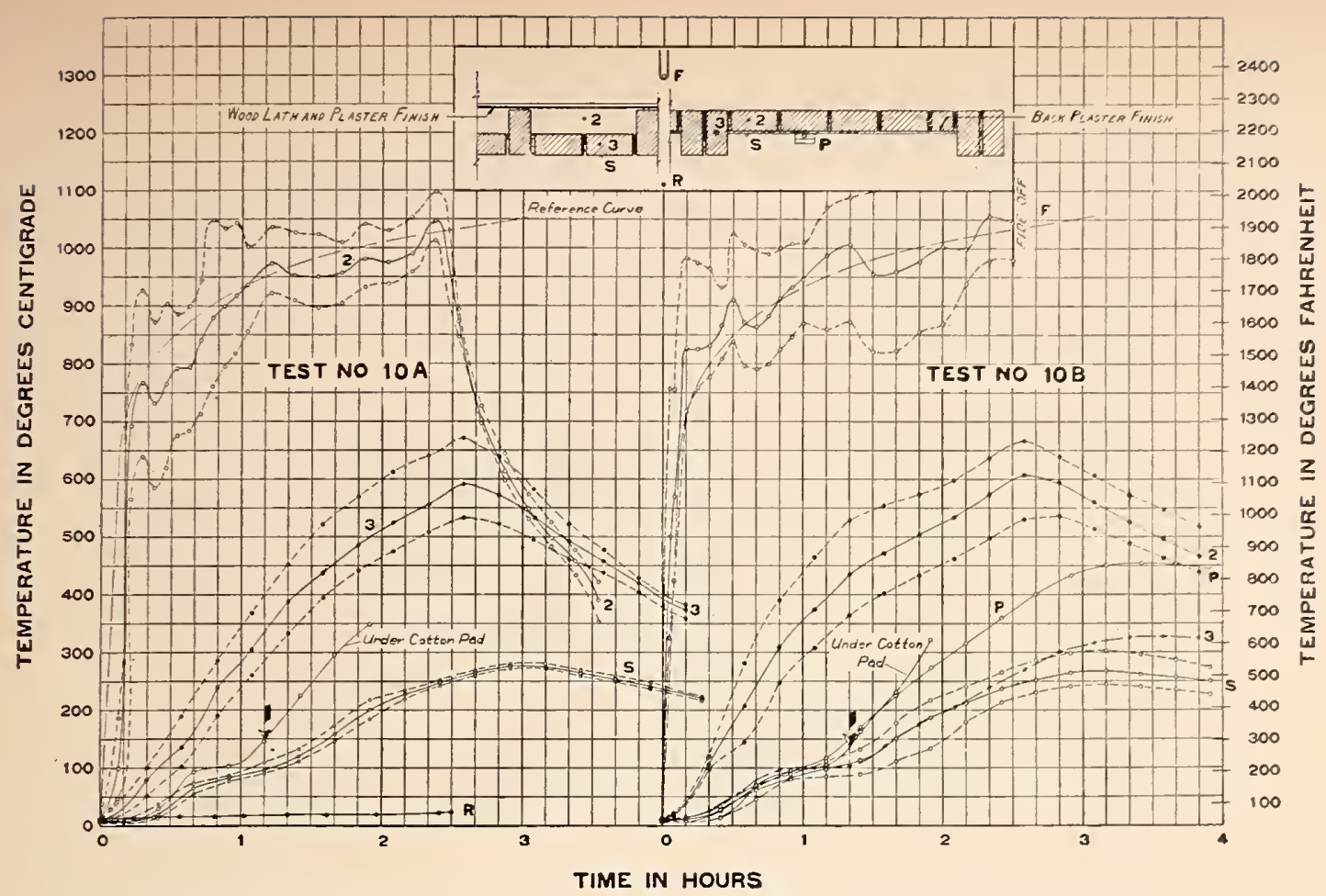

Figtre 7. Temperatures in fire-endurance test of 4 -in. pilastered walls $10 \mathrm{~A}$ and $10 \mathrm{~B}$.

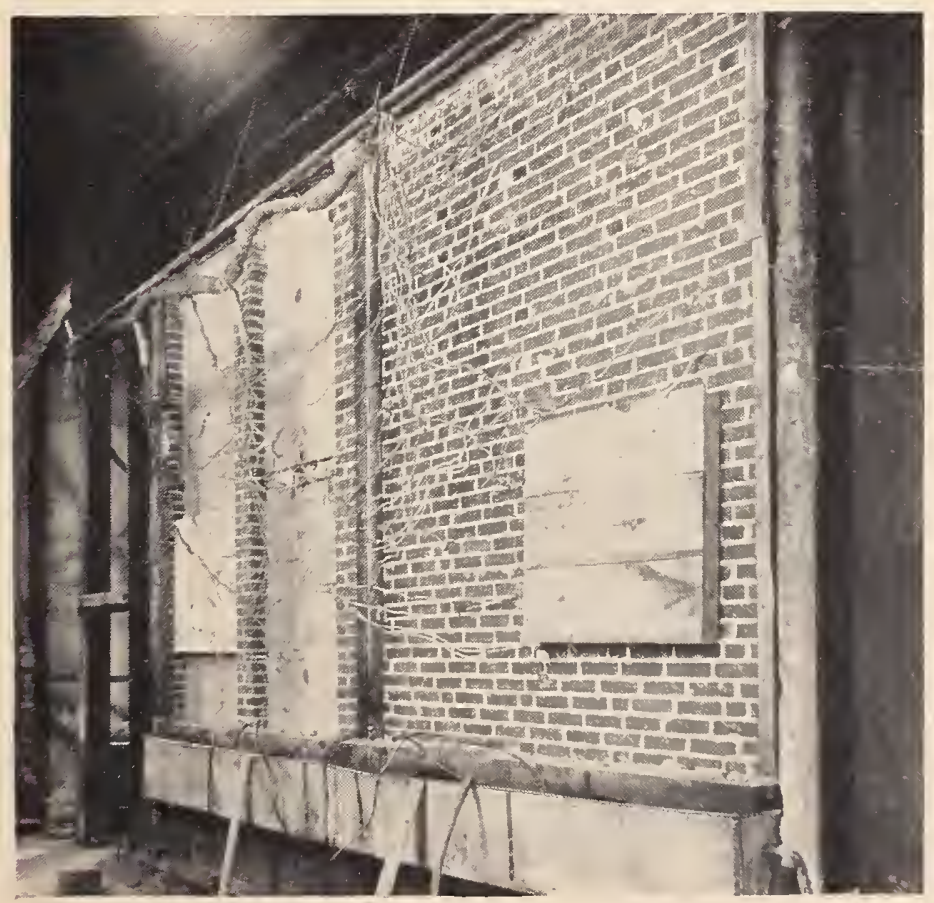

FIGURE 8. Unexposed side of walls 10.4 and $10 \mathrm{~B}$ bcjore test. 


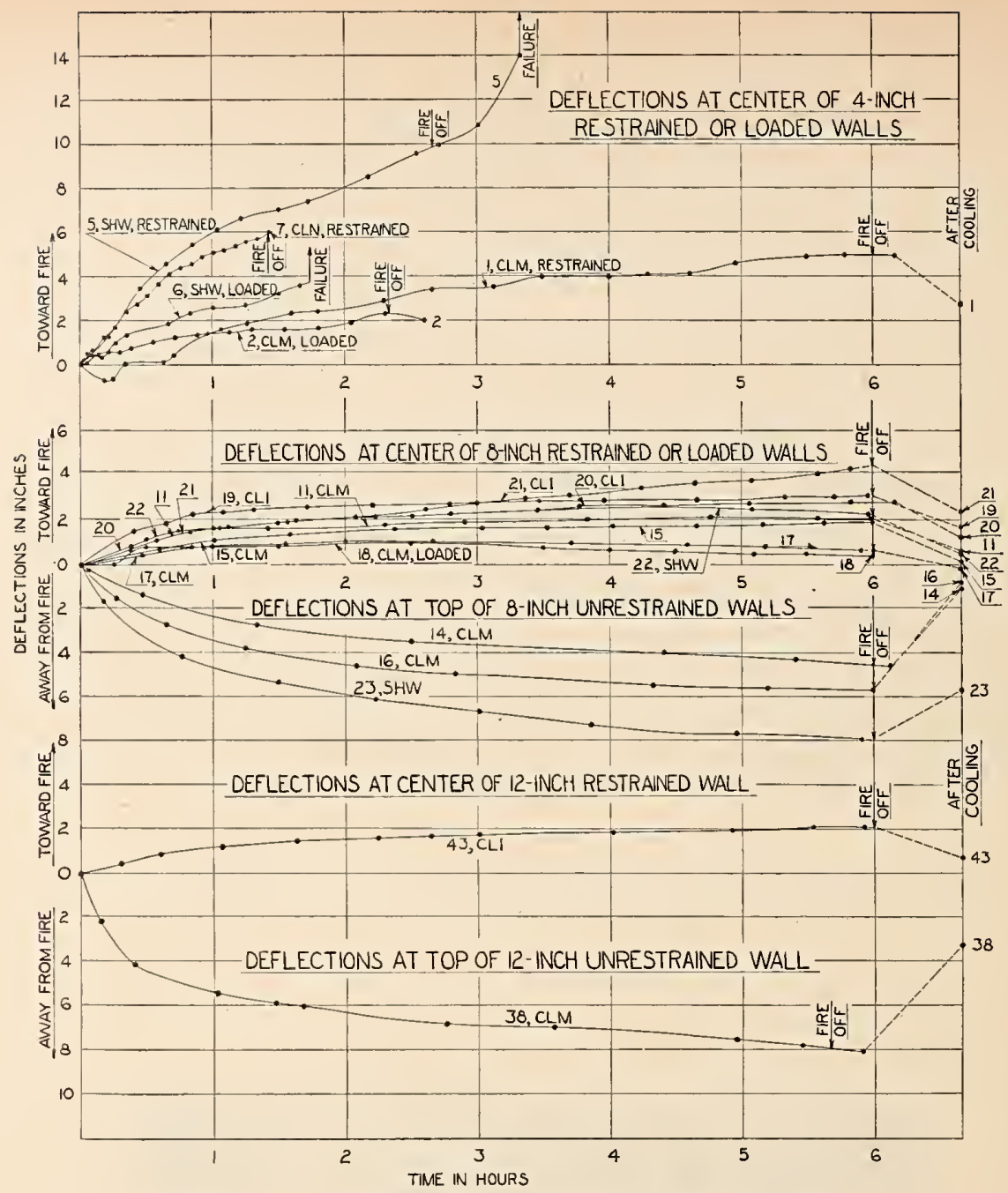

Figure 9. Deflections of solid walls of clay and shale bricks.

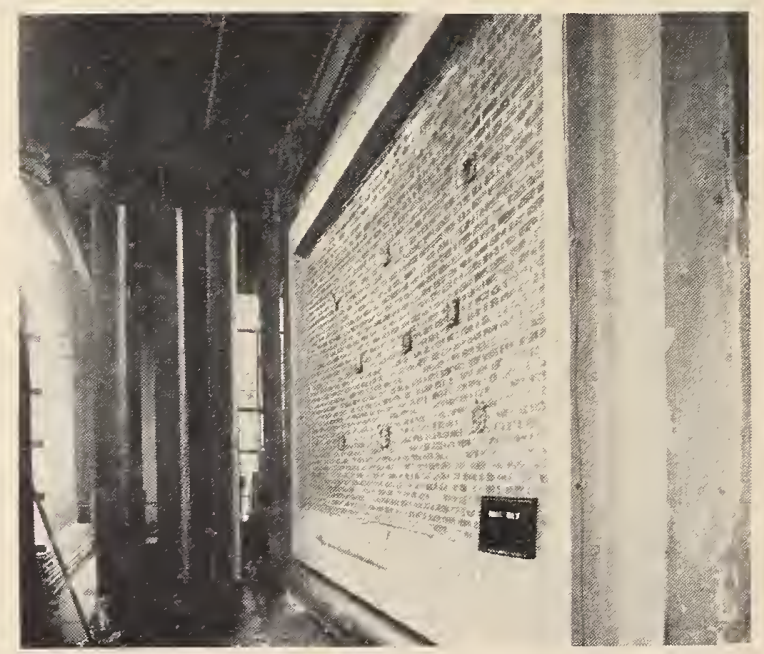

Figure 10. Unexposed side of 4 -in. wall 7 after fire-endurance and hose-stream tests. 


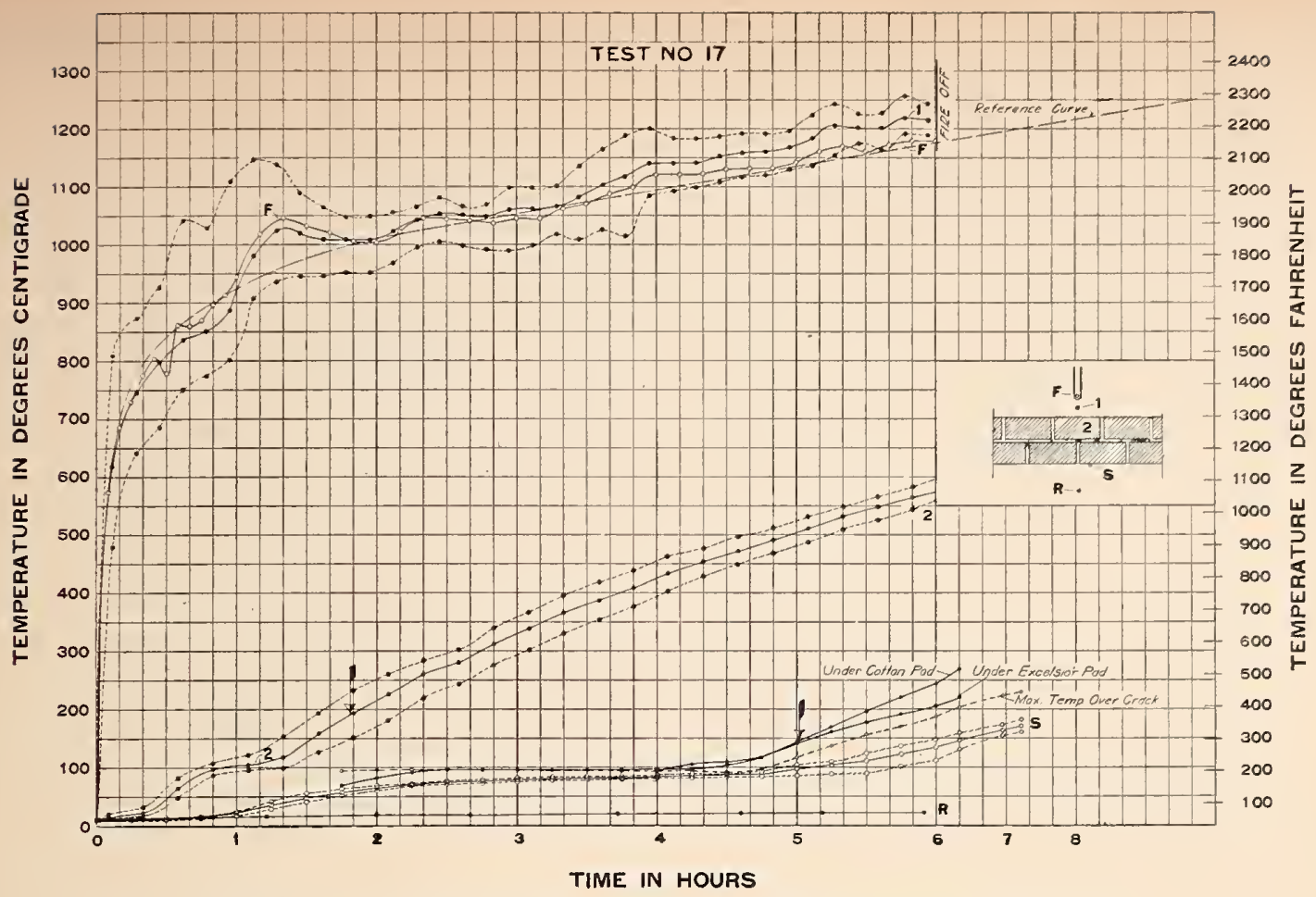

FIGURE 11. Temperatures in fire-endurance test of solid clay-brick wall 17.

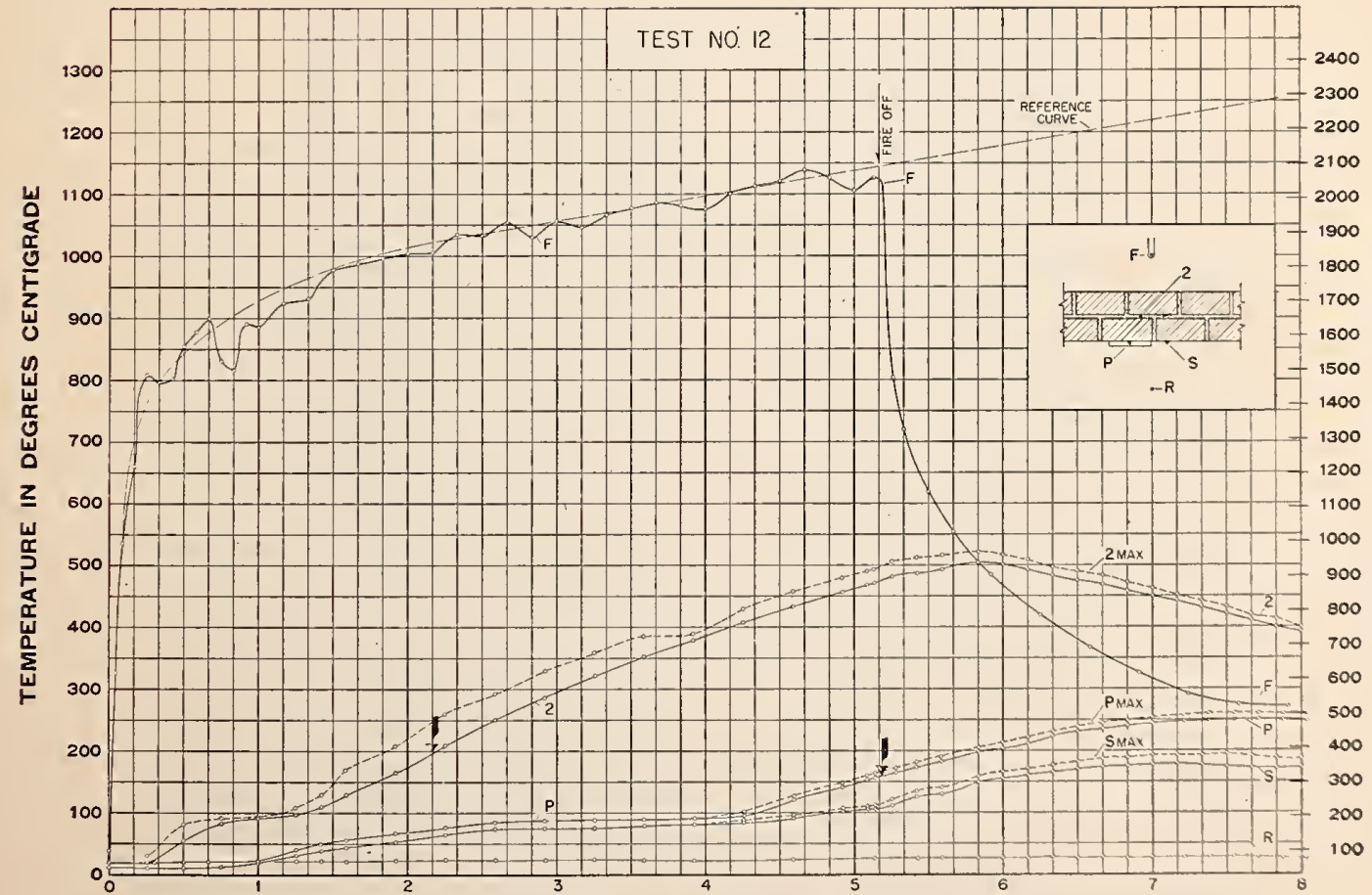

TIME IN HOURS

FIGURE 12. Temperatures in fire-endurance test of solid rlay-brick wall 12. 


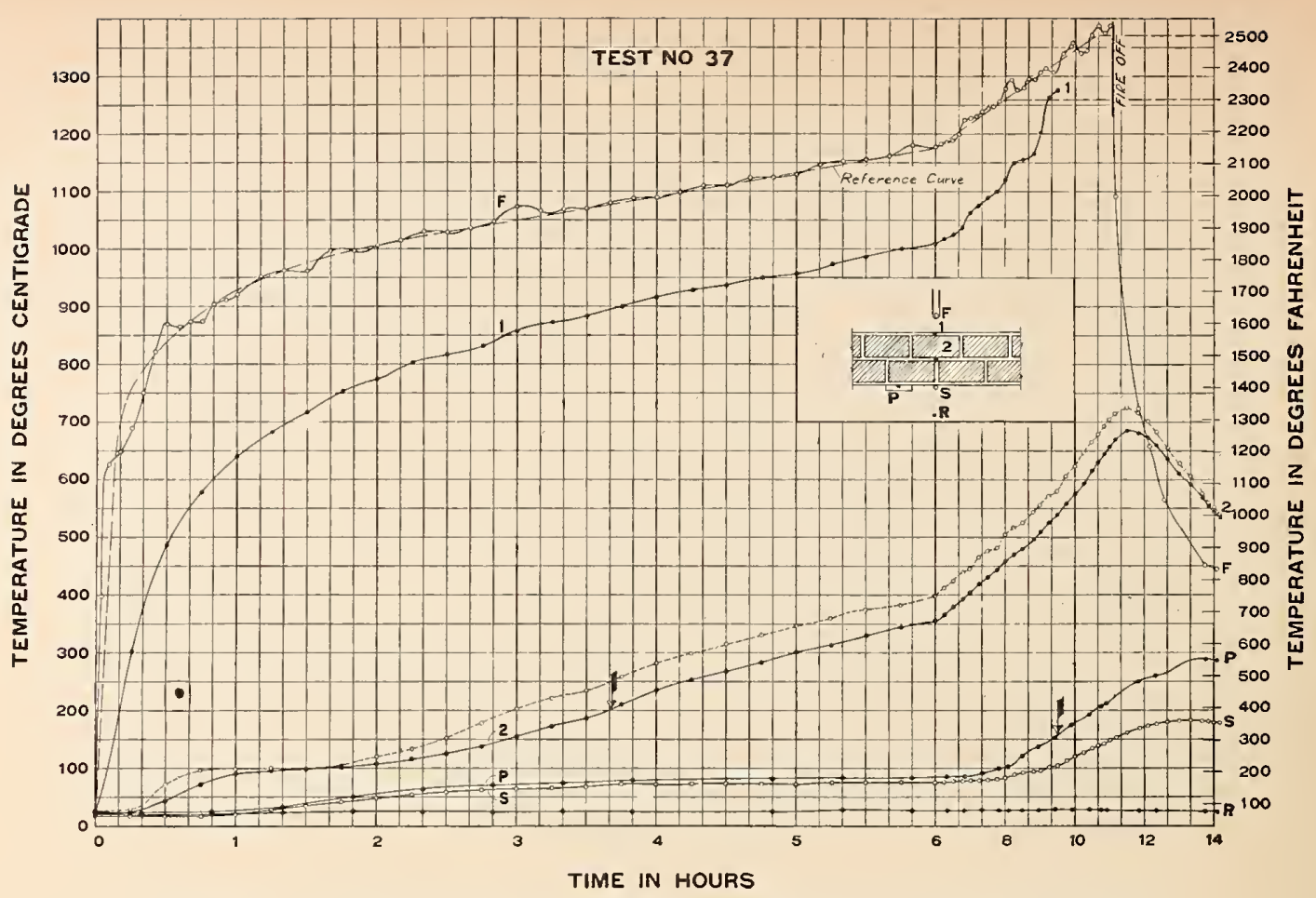

Figure 13. Temperatures in fire-endurance test of plastered solid clay-brick wall 37 .

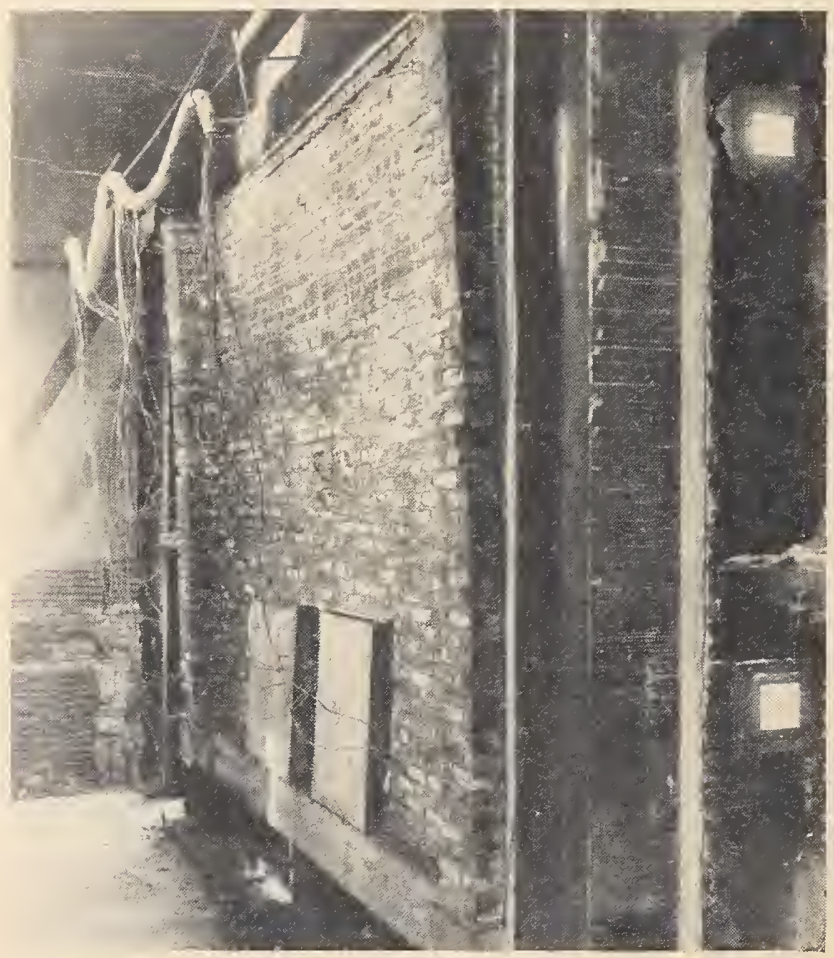

FIgURE 14. Unexposed side of 8-in. unrestrained wall 14 at end of 6 -hr fire test. 
laid up in lime mortar, no crack having an opening over $1 / 32$ in. was observed. As the object of the test in the unrestrained condition was mainly to determine stability, the low limit of temperature rise for wall 16 may not be significant.

The cracks formed in walls tested unrestrained were wider and in greater number and extent than for those tested restrained within the panel frame. For the latter condition, they scldom had width exceeding $1 / 16$ in. with the present group of walls, while for the unrestrained condition a number of cracks had openings of $3 / 16$ to $5 / 16$ in. on the unexposed side of the wall. As tested restrained, there was little difference in the matter of cracks observed as due to the three types of mortar used, namely, cement, cement-lime, and lime. This also applies for the effect of brick materials from the three sources, CLMI, CLI, and SHW. Tested unrestrained, cracks of the greatest extent and width were evidenced for wall 16 of clay bricks laid up in lime mortar and for wall 23 of shale bricks in cement-lime mortar.

In some tests, the central part of the wall slid inward from $1 / 16$ to $3 / 4$ in. at the second to sixth course from the base due to the force of the inward deflection. However, resulting openings were not over $1 / 8$ in. wide.

Openings on the unexposed side were formed between the wall under test and the frame, occurring at the base of unrestrained walls, at the base and top for the loaded walls, and also at the sides for walls tested restrained. At the sides, these openings did not exceed $1 / 1$, in. and apparently had no effect on the performance of the wall.
At the base of the wall, there were openings up to $1 / 4$ in. at the outer face. While the lower edge of the large cotton pad and excelsior hox were resting in most tests on the restraining frams at the base of the wall, no ignition or scorching from these cracks at the bottom margin was noterl. This was probably rlue to an inward elraft of colrl air where the crack communicated with the furnace chamber.

Between the panel frame and the top of restrained walls, openings up to $3 / 8 \mathrm{in}$. in width were formed at the outer surface. These closed up or became smaller as the fire-exposed face was approached. The limited number of determinations made indicated temperatures at these openings up to the ignition point of wood or other orrlinary combustible materials in immediate contact. at $2 \frac{1}{2}$ to $3 \mathrm{hr}$ after the start of the test. It is unlikely that room contents would be in contact at the top of the wall. Further, wood in cornice molds, generally applied only on plastered construction and with the inner corner cut back, would not be within $1 \frac{1}{2}$ or 2 in. from such an opening.

(6) Fusion and spalling effects. With walls of clay bricks from source CLMI, there was no fusion or spalling of bricks during a 6-hr fire test. The fire-exposed side of such a wall after test is shown in figure 15.

With walls of clay bricks from source CLI, there was considerable fusion and fluxing of the bricks on the lower part of the wall where the furnace temperatures were highest (fig. 16). This began after 4-hr fire exposure, most of it occurring during the last hour of the 6-hr fire

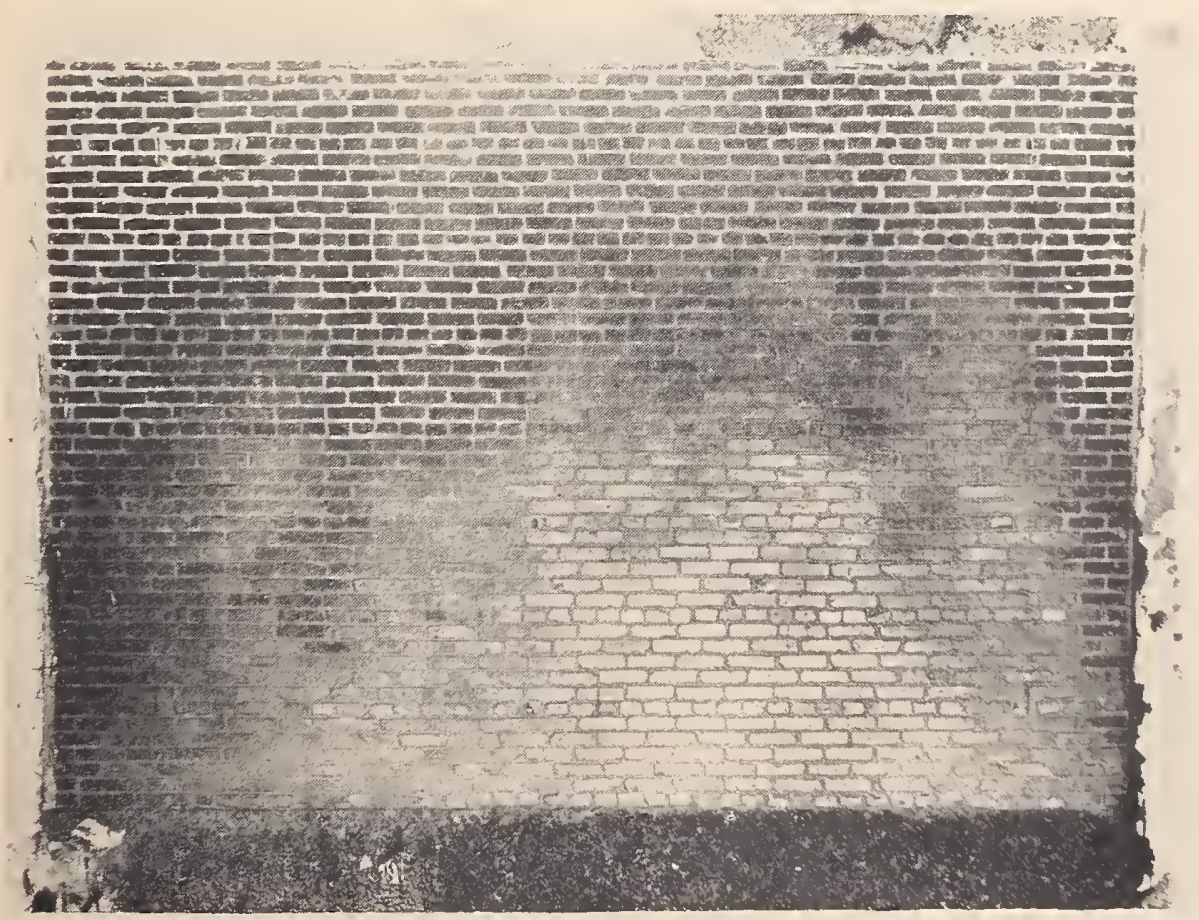

Figure 15. Fire-exposed side of wall 11 of clay bricks from soure CL.M after ti-hr fire test 
test. The depth of fusion was from $1 / 2$ to 1 in. The softening point of this brick is near $2,100^{\circ} \mathrm{F}$. The fusion, apparently had little effect on the fire resistance of the walls.

With walls of shale bricks (source SHW) the fusion was limited to near the exposed surface with little running of fused material (fig. 17). With wall 22 tested restrained there was spalling of bricks on the fire-exposed side to depths of $1 / 4$ to $1 / 2$ in. For wall 23, tested unrestrained, there was no spalling but there were cracks in the bricks parallel with the surface at a depth of $1 / 2$ to $1 \frac{1 / 2}{2}$ in.

In figure 18 is shown the fire-exposed side of wall 37 after the 11-hr fire test. It was built of clay br.cks from source CLM and had gypsum plaster on both sides. The furnace temperatures during the last $2 \mathrm{hr}$ of the test were in the range $2,400^{\circ}$ to $2,500^{\circ} \mathrm{F}$. The fusion apparently affected the mortar joints more than the bricks, and the plaster before it sloughed off probably also had a fluxing effect.

\section{c. Concrete and Sand-Lime Brick Walls of 8-in. Thickness}

This group comprises walls 25 to 36 , of which 6 were large walls tester to 6 lir and 6 were small walls tested for longer periods.

(1) Surface-temperature rise. In no test was a temperature-rise limit reached on the unexposed surface within $6 \mathrm{hr}$ in the regular thermocouple locations. In the test of wall 26 , a temperature rise of 325 deg $\mathrm{F}$ occurred at 5 hr 6 min over a hole in a mortar joint (table 9 ).

For wall 27, of concrete bricks normally seasoned, the temperature rise of $250 \mathrm{deg} F$ under the standard asbestos pad occurred at $6 \mathrm{hr} 59$ min (fig. 19). With wall 28, dried to constant weight at elevated temperatures, the same limit was reached at $6 \mathrm{hr} 14 \mathrm{~min}$.

In tests of walls of sand-lime bricks, the surfacetemperature rise was slower than with bricks of other types, although for the tests with bricks from source SLD, this was due in part to bricks wider than the standard $3 \frac{3 / 4}{-1 n}$. width by $1 / 2$ to $3 / 4$ in. A temperature rise of 325 deg $F$ occurred at a crack 64 min after the fire was off in test of wall 29 of sand-lime bricks from source SLP (fig. 20).

In fire test of wall 33, of sand-lime bricks from source SLD and seasoned under room conditions for 77 days, the limit of 250-rleg $F$ temperature rise on the surface was reached at $10 \mathrm{hr} 6 \mathrm{~min}$ (table 9). With similar wall 35 , dried at higher temperatures, the same limit obtained at $7 \mathrm{hr} 42$ min. With wall 36 , buillt of sand-lime bricks from source SLO, having width near the standard $3 \frac{3}{4}$ in. and dried at the higher temperatures, the 250-deg F surface-temperature limit was reached at 6 hr $39 \mathrm{~min}$.

(2) Temperature limits within wall. For walls of concrete bricks normally seasoned, the time at which an average temperature rise of 325 deg was reached at the midplane of the wall ranged from $2 \mathrm{hr} 41 \mathrm{~min}$ to $3 \mathrm{hr} 33 \mathrm{~min}$ (table 9). For wall 28, which was dried to constant weight, the limit was reached at 2 hr 30 min.

In tests of five walls of sand-lime bricks normally seasoned (walls 29 to 33 ), the rise of 325 deg $F$ in the wall was reached at an average of $3 \mathrm{hr} 43 \mathrm{~min}$. As dried at elevated temperatures, this was reduced to $3 \mathrm{hr} 2 \mathrm{~min}$ for wall 35 of bricks from source SLD, and to $2 \mathrm{hr} 46 \mathrm{~min}$ for wall 36 , built of the smaller bricks from source SLO.

(3) Load-carrying ability and lateral deflections. Wall 28, of concrete bricks from source COE, was tested under load of $160 \mathrm{lb} / \mathrm{in}^{2}$, which was sustained in a fire test of $6 \mathrm{hr} 17 \mathrm{~min}$ (table 9). A pier cut from the wall after test had a compressive strength of $430 \mathrm{lb} / \mathrm{in}^{2}{ }^{2}$ and that of the companion pier not subjected to fire test, $940 \mathrm{lb} / \mathrm{in} .^{2}$ (table 5).

IVall 32, of sand-lime bricks from source SLD, carried a load of $146 \mathrm{lb} / \mathrm{in}^{2}{ }^{2}$ during a 6 -hr fire test. The strength of the companion masonry pier was $710 \mathrm{lb} / \mathrm{in}^{2}$ and for a pier cut from the wall after the fire test, $450 \mathrm{lb} / \mathrm{in}^{2}$ The maximum lateral deflection during the fire test was $0.70 \mathrm{in}$. Wall 46 of sand-lime bricks from the same source supported a load of $160 \mathrm{lb} / \mathrm{in} .^{2}$ during an 8 -hr fire test.

The lateral deflections of solid walls of concrete and sand-lime bricks are plotted in figure 21 . There was no collapse of either restrained or unrestrained walls from excessive deflections. As indicated in par. b (4) above for clay and shale brick walls, the average top deflection at the end of 6 -hr fire tests of unrestrained walls, was about four times the center deflection of restrained walls.

(4) Cracks and other fire effects. The extent of cracking of the walls during test was about the same as for the 8-in. clay- and shale-brick walls. For those tested restrained, cracks in the body of the wall were rarely more than $1 / 16$ in. in width. However, as tested unrestrained, many diagonal cracks were formed with openings in the range $1 / 4$ to $5 / 8$ in.

The openings that developed between wall and frame were not of such extent as to affect the fire resistance. The same applies for horizontal displacements of brick courses with reference to each other.

For concrete-brick walls tested for 6 to $8 \mathrm{hr}$, there was fusion of the bricks to a depth of $1 / 2 \mathrm{in}$., but the fused material remained largely in place (fig. 22). A few bricks spalled to a depth of $3 / 4 \mathrm{in}$. The bricks were, in general, dehyclrated and weak for a depth of 2 to $3 \mathrm{in}$. from the fire-exposed side.

With walls of sand-lime bricks tested for $6 \mathrm{hr}$, there was no fusion of brick or mortar (fig. 23). For longer test durations up to $10 \mathrm{hr}$, the mortar in the joints fused to depths of $1 \mathrm{in}$. The fireexposed bricks were crazed and cracked to the extent of falling to pieces under light impacts after removal from the wall.

\section{d. Solid Walls of 12-in. Thickness}

The present group of 16 tests (walls 38 to 53 , table 9) was marle with 12-in. walls, one or more of which were built of bricks from the sources 


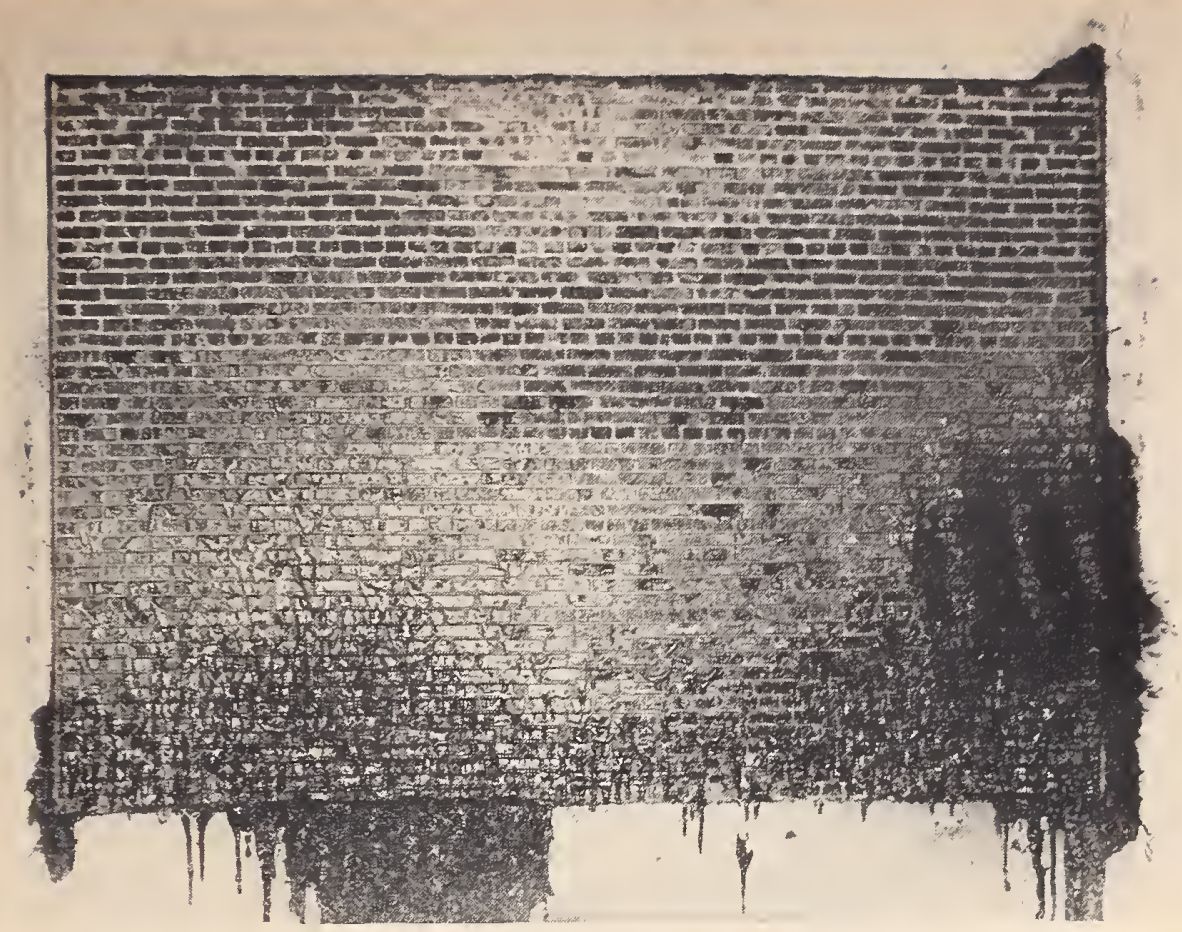

FigURE 16. Fire-exposed side of wall 21 of clay bricks from source CLI after 6-hr fire test.

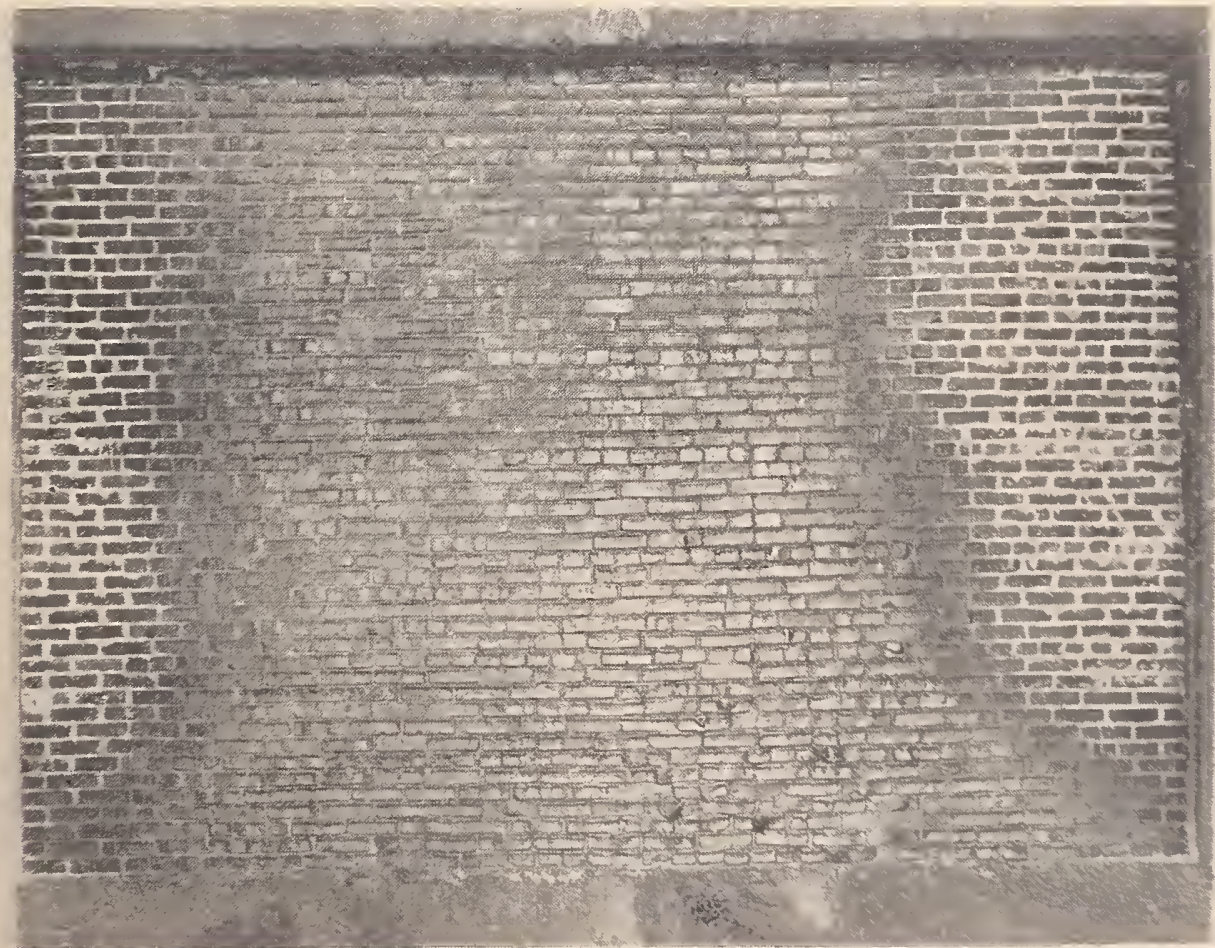

FIGURE 17. Fire-exposed side of shale-brick wall 23 after 6 -hr fire test. 


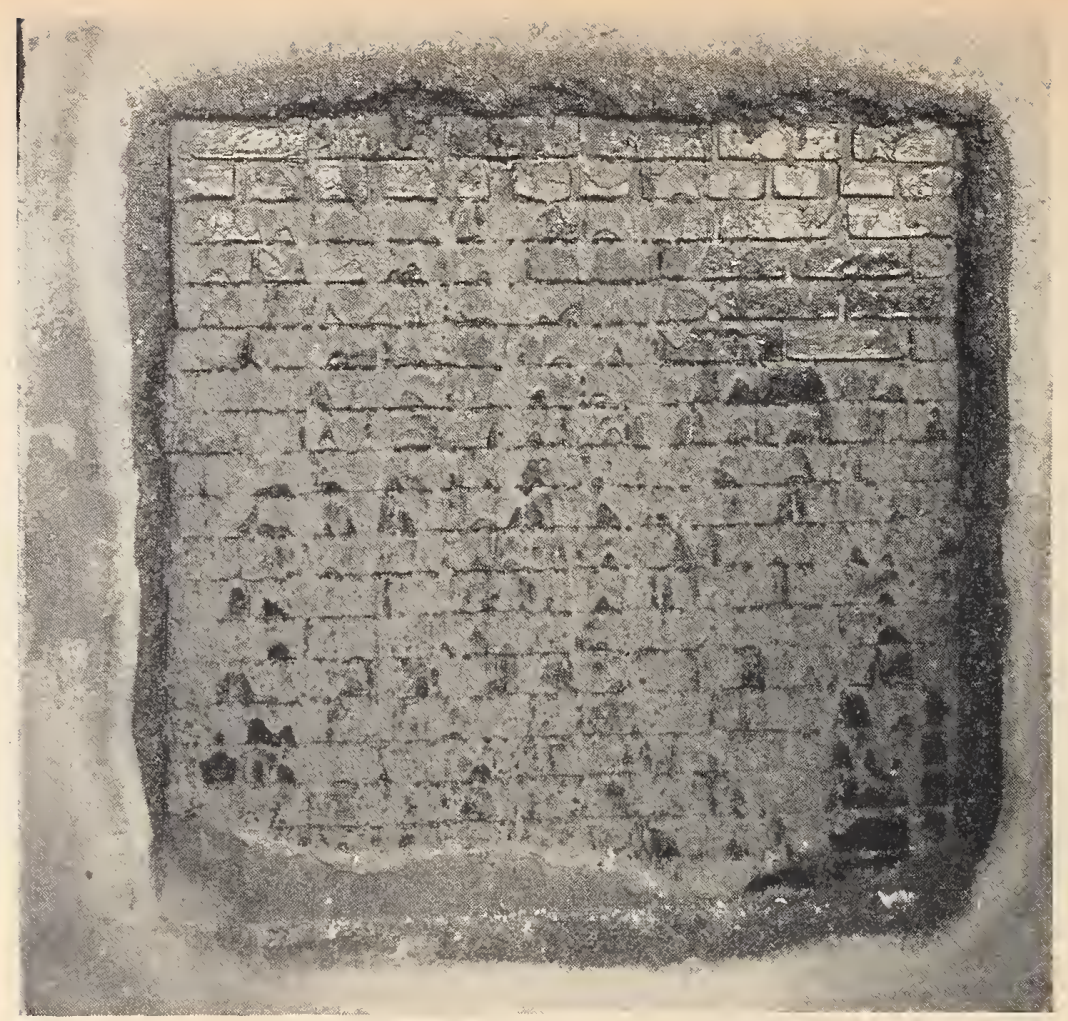

Figure 18. Fire-exposed side of plastered clay-brick wall 37 after 11-hr fire test.

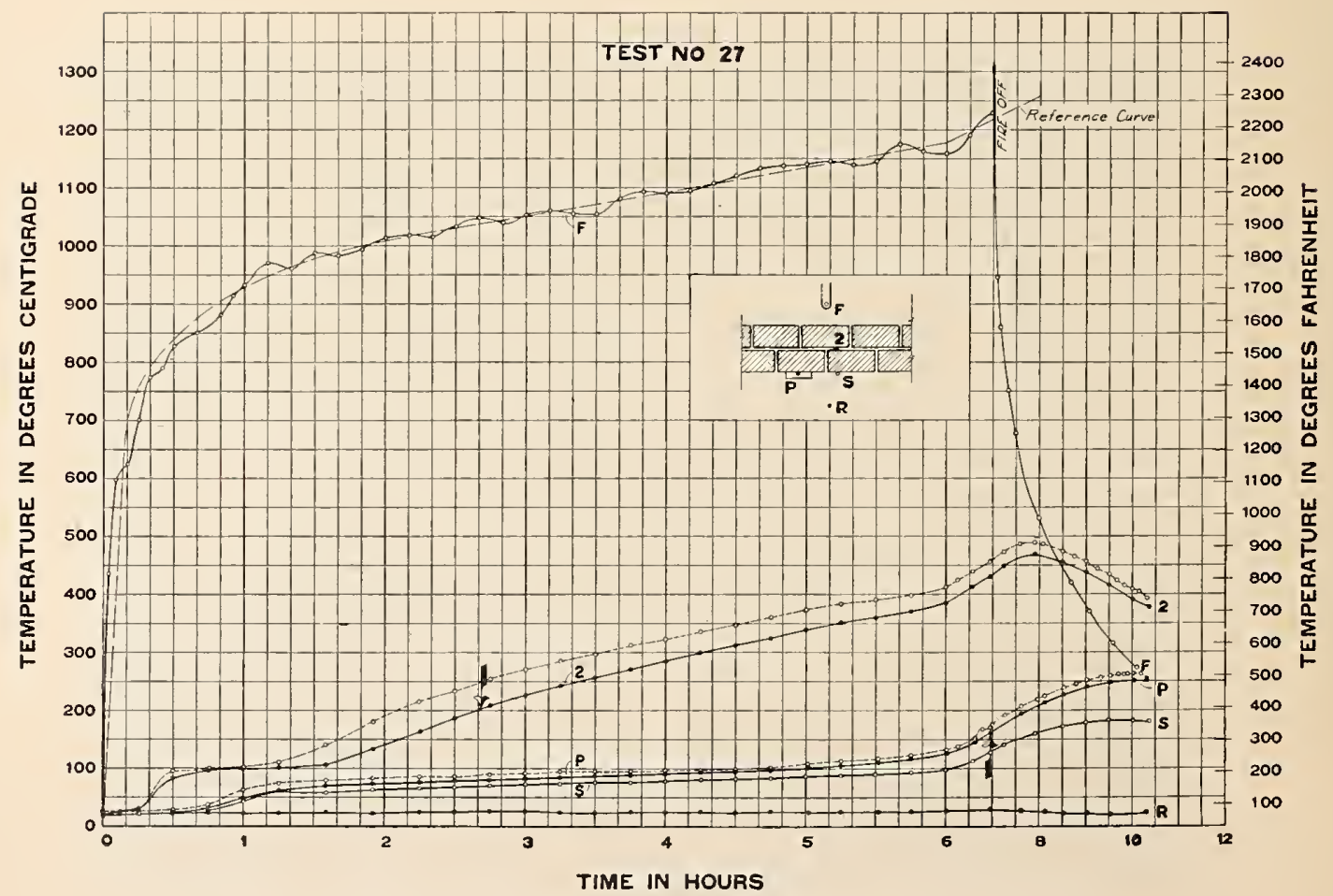

FIGURE 19. Temperatures in fire-endurance test of 8-in. concrete-brick wall $2 \gamma$. 


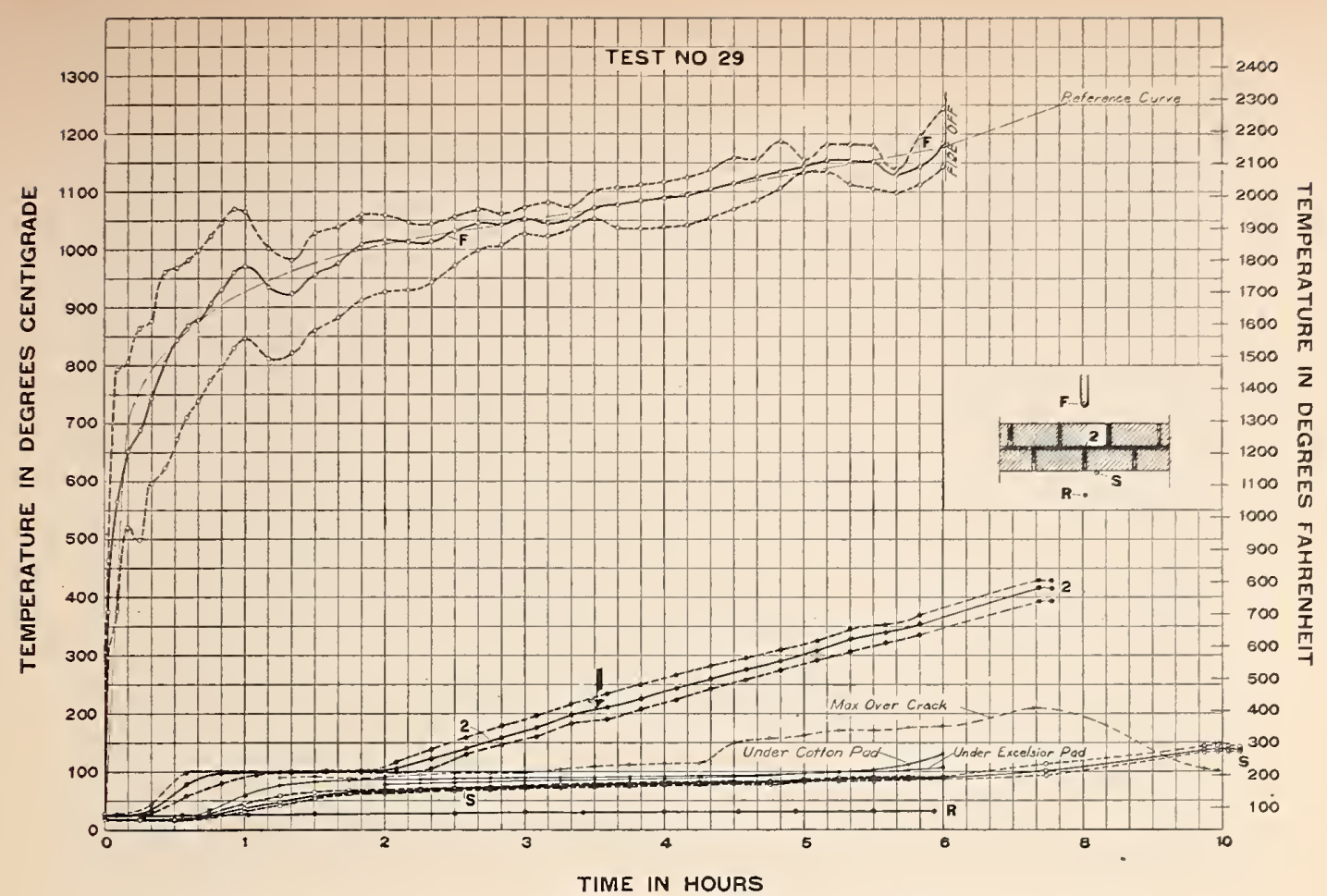

FIGURE 20. Temperatures in fire-endurance test of 8-in. sand-lime brick wall 29.

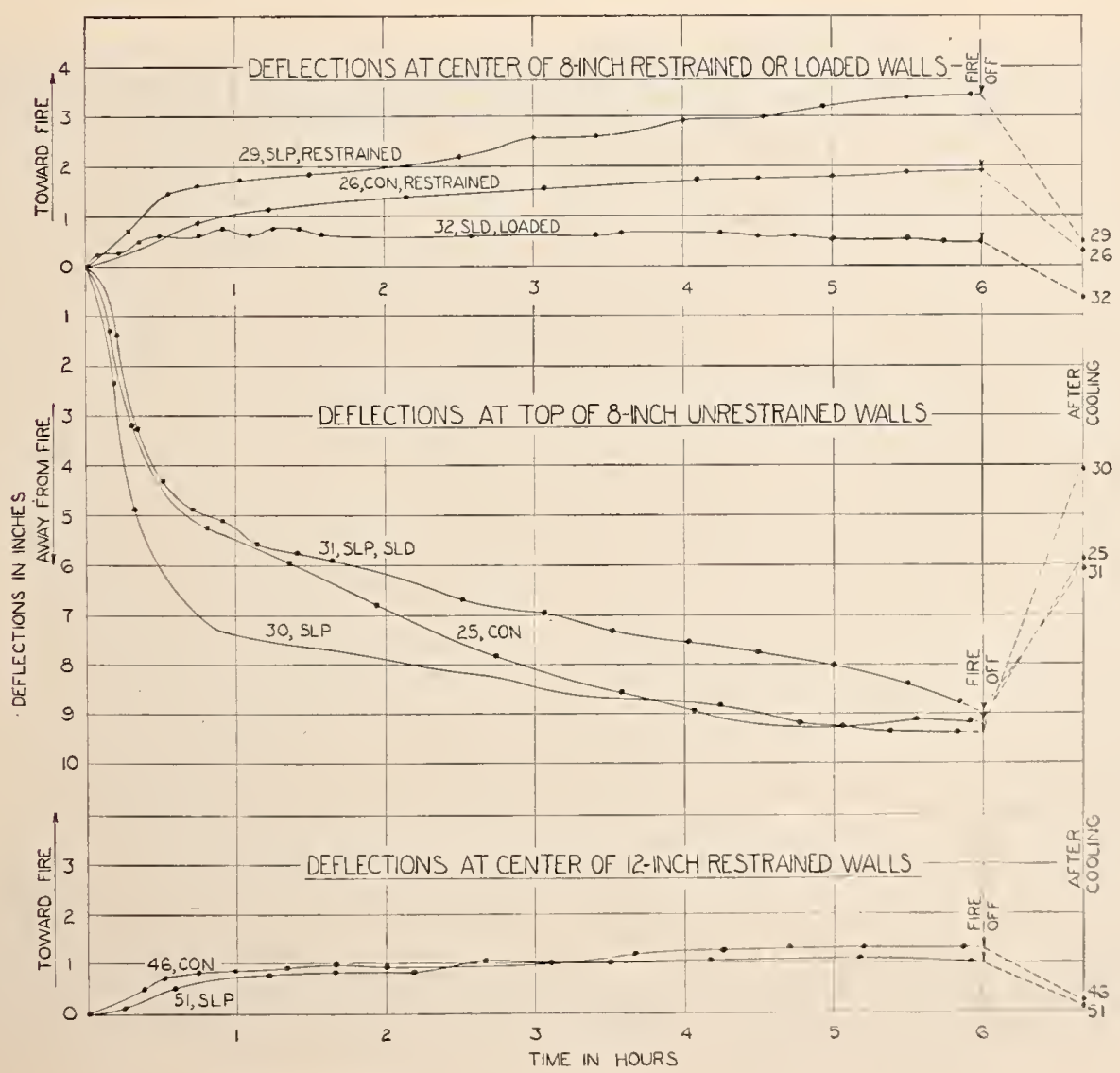

Figure 21. Deflections of solid walls of concrete and sand-lime bricks. 


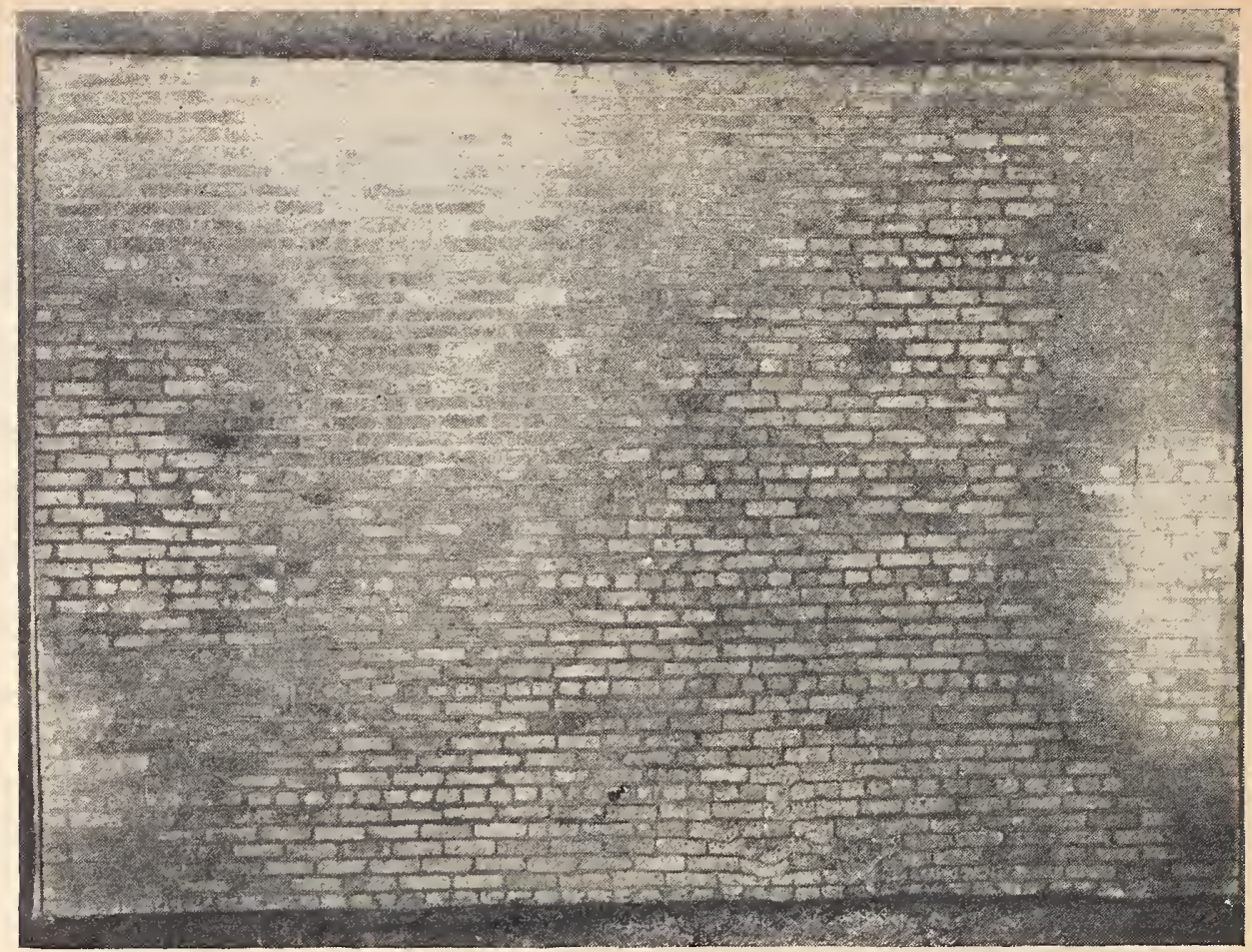

Figure 22. Fire-exposed side of 8-in. concrete-brick wall 25 after 6 -hr fire test.

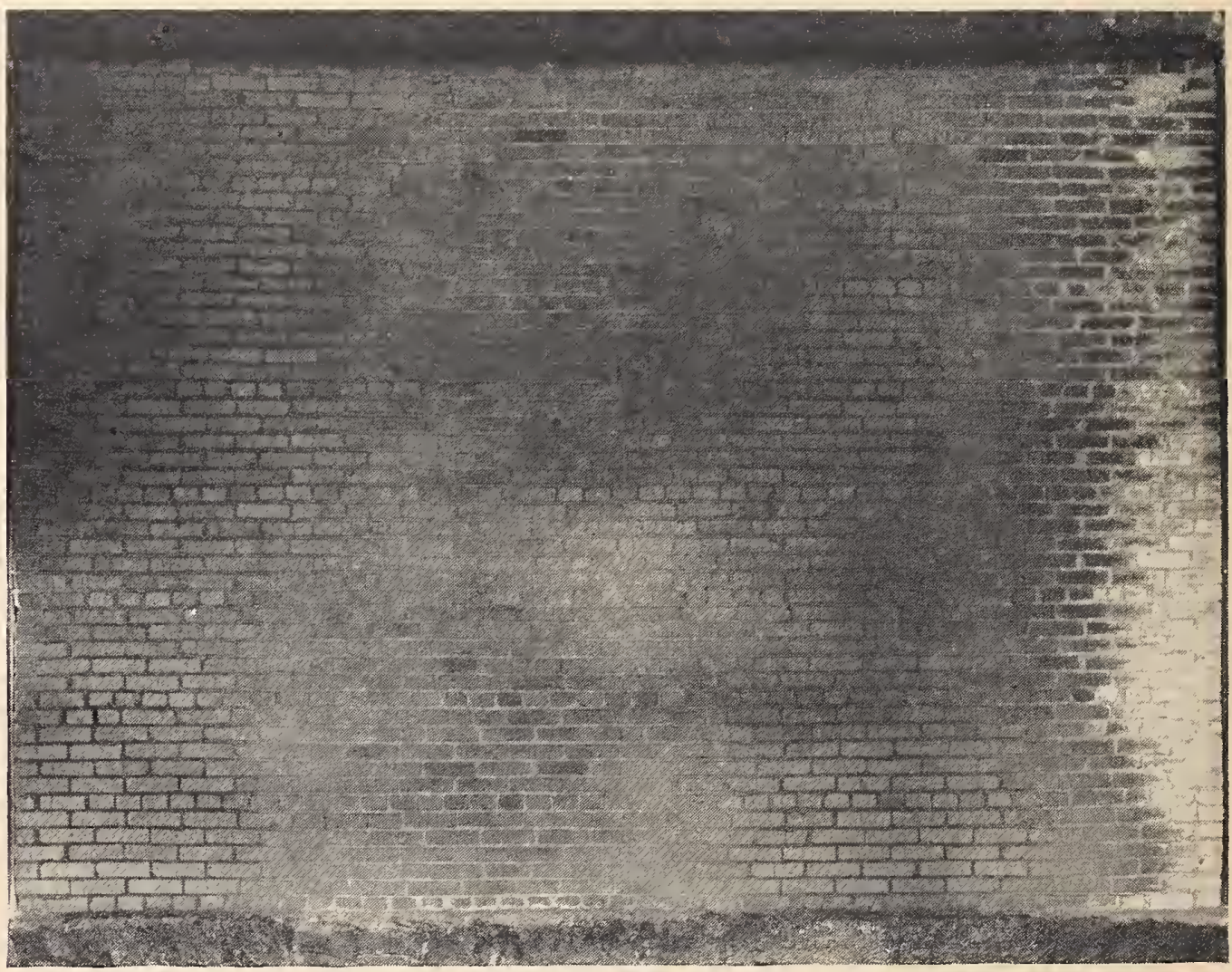

Figure 23. Fire-exposed side of 8-in. sand-lime brick wall 30 after 6-hr fire test. 
represented in the present series of tests. Only four of these walls were of the larger size.

(1) Surface-temperature limits. With the four large walls in the first group that were tested to $6 \mathrm{hr}$ or less (rralls $38,43,46$, and 51 ), the average temperature rise on the free surface did not exceel $119 \mathrm{deg}$ F. This represents a rise far below the permissible limit of $250 \mathrm{deg} \mathrm{F}$, as determined uncler the asbestos pads. Nor did temperatures go higher than 220 deg F under the large cotton pad and excelsior box or over cracks. Typical time-temperature curves from these tests are given in figure 24 .

In tests of longer duration. made with walls of the smaller size, the information obtained on fire endurance based on temperature rise is limited by failure of some of the walls under load or ending of the test before the limiting temperature rise was reached. For clay-brick wall 40, that had been dried to constant weight, the limit of $250 \mathrm{deg}$ $\mathrm{F}$ arerage rise was reached at $10 \mathrm{hr} 19 \mathrm{~min}$ (fig. 25). For shale-brick wall 45 , seasoned under room conditions for 77 days, the limit was reached at 12 hr 49 min.

The fire-endurance limit based on average surface-temperature rise was reached for 12-in. concrete-brick wall 47 at $16 \mathrm{hr} 9 \mathrm{~min}$. This wall was of the small size and seasoned under room conditions for 82 days. With similar walls 49 and 50 , that were dried to constant weight at higher temperatures, the limit was reached at $13 \mathrm{hr} 47 \mathrm{~min}$ and $13 \mathrm{hr} 57 \mathrm{~min}$, respectively.

The surface-temperature limits were not determined with 12-in. walls of sand-lime bricks because wall 51 was tested only to $6 \mathrm{hr}$, and walls 52 and 53 failed under load before the limit was reached.

The results of all fire tests of 12 -in. walls in the smaller size should be applied with due consideration for the more favorable conditions attributable to size as compared with those of walls having dimensions approximating constructions in buildings. This will be given consideration in evaluating the results of the tests.

(2) Temperature rise in wall. The average temperature rise of $325 \mathrm{deg} F 4$ in. from the unexposed side was not reached in any of the tests of large walls terminated at $6 \mathrm{hr}$. For wall 40, of clay bricks from source CLM, which was dried to constant weight at temperatures in the range $160^{\circ}$ to $180^{\circ} \mathrm{F}$, the limit of average temperature rise in the wall was reached at $6 \mathrm{hr} 38 \mathrm{~min}$. With wall 44, of clay bricks from source CLI, and with wall 45 , of shale bricks, both seasoned under room conditions, the limits were reached at $7 \mathrm{hr} 32 \mathrm{~min}$ and $8 \mathrm{hr} 33 \mathrm{~min}$, respectively.

For wall 42 , of clay bricks with lime plaster on the fire-exposed side, the temperature-rise limit in the wall was reached at $9 \mathrm{hr} 14 \mathrm{~min}$. Although the plaster fell off during the first $12 \mathrm{~min}$ of the test, it apparently had retarded drying of the wall, which was tested at the age of 41 days.

In the tests with walls of concrete bricks, the temperature-rise limit in the wall came at $11 \mathrm{hr}$
30 min for wall 47 seasoned under room conditions and at $10 \mathrm{hr} 18 \mathrm{~min}$ and $10 \mathrm{hr} 17 \mathrm{~min}$, respectively, for walls 49 and 50 that were dried to constant weight at higher temperatures. 'Thr limit of walltemperature rise was reached at $10 \mathrm{hr} 43 \mathrm{~min}$ with wall 5.3 of sand-lime bricks, which was also dried to constant weight at the higher temperatures.

Because the limits of wall-trmperature riss: were obtained with walls of the smaller size, the determinations are subject to the same limitations as indicated above for limits of temperature rise on the surface.

(3) Lateral deflection. The maximum deflection of clay-brick wall 43, tested restrained, was near $2 \mathrm{in}$. and the outward deflection at the top of wall 38 , tested unrestrained, was about 8 in. at the end of the fire test (fig. 9). A view of the tested wall is given in figure 26 . With the concrete and sand-lime brick walls tested restrained, the center deflection did not exceed 1.3 in. (fig. 21)

The deflections of the $12-\mathrm{in}$. walls of $11-\mathrm{ft}$ height, as tested for $6 \mathrm{hr}$, were not such as to seriously endanger stability or decrease to significant extent the ability of the walls to support the working load. Near the end of the test, the deflections were constant or decreasing, hence a longer fire exposure may not be critical from this standpoint.

(4) Cracks and imperfect joints. There were only very fine cracks on the unexposed side of 12 -in. walls, except that for the ones that failed under load larger cracks began to show at 10 to $15 \mathrm{~min}$ before failure. Openings on the unexposed side between frame and wall had a maximum of $3 / 8$ in. width with wall 43 , for which the maximum center deflection was near 2 in. (fig. 9). With walls 46 and 51 having lower deflections (fig. 21). these openings were not noticeable.

Steam and hot gases issued from holes in mortar joints, but no temperatures higher than 220 deg $\mathrm{F}$ were indicated over them for the large walls tested to $6 \mathrm{hr}$ or less.

(5) Fusion of brick and mortar. In the fire tests of large walls limited to $6 \mathrm{hr}$, there was no appreciable fusion of wall material except for wall 43 , of clay bricks from source CLI, where there was fusion and fluxing of the bricks to about the same extent as for the 8 -in. Walls of bricks from this source. In tests of longer duration, there was more fusion, depending upon the brick material and duration of the tests.

Although clay brick from source CLA had in relatively high softening point, there was a limited amount of fusion in tests of the longer cluritions (fig. 27). For wall 44, of clay bricks from somere CLI, most of the fire-exposed course wis thured away during the 10 lir 21 min test. With shisle bricks, the fusion effect was of intermediate denres (fig. 28).

With conerete and sand-lime brieks, the fosion effects were dependent upon the sami and other aggregates used. With walls ti and 45 , of con- 


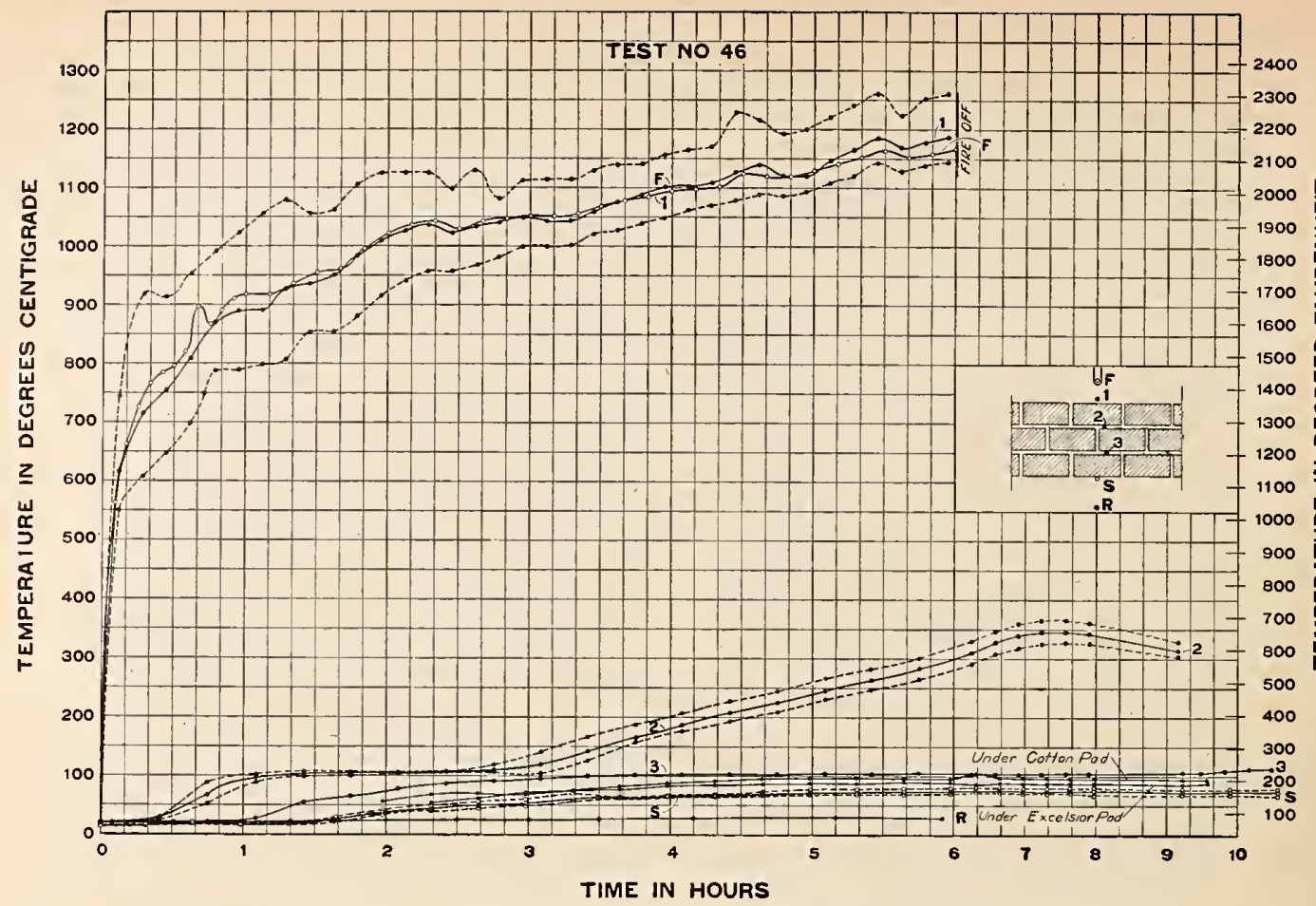

FIGURE 24. Temperatures in fire-endurance test of 12-in. concrete brick wall 46 .

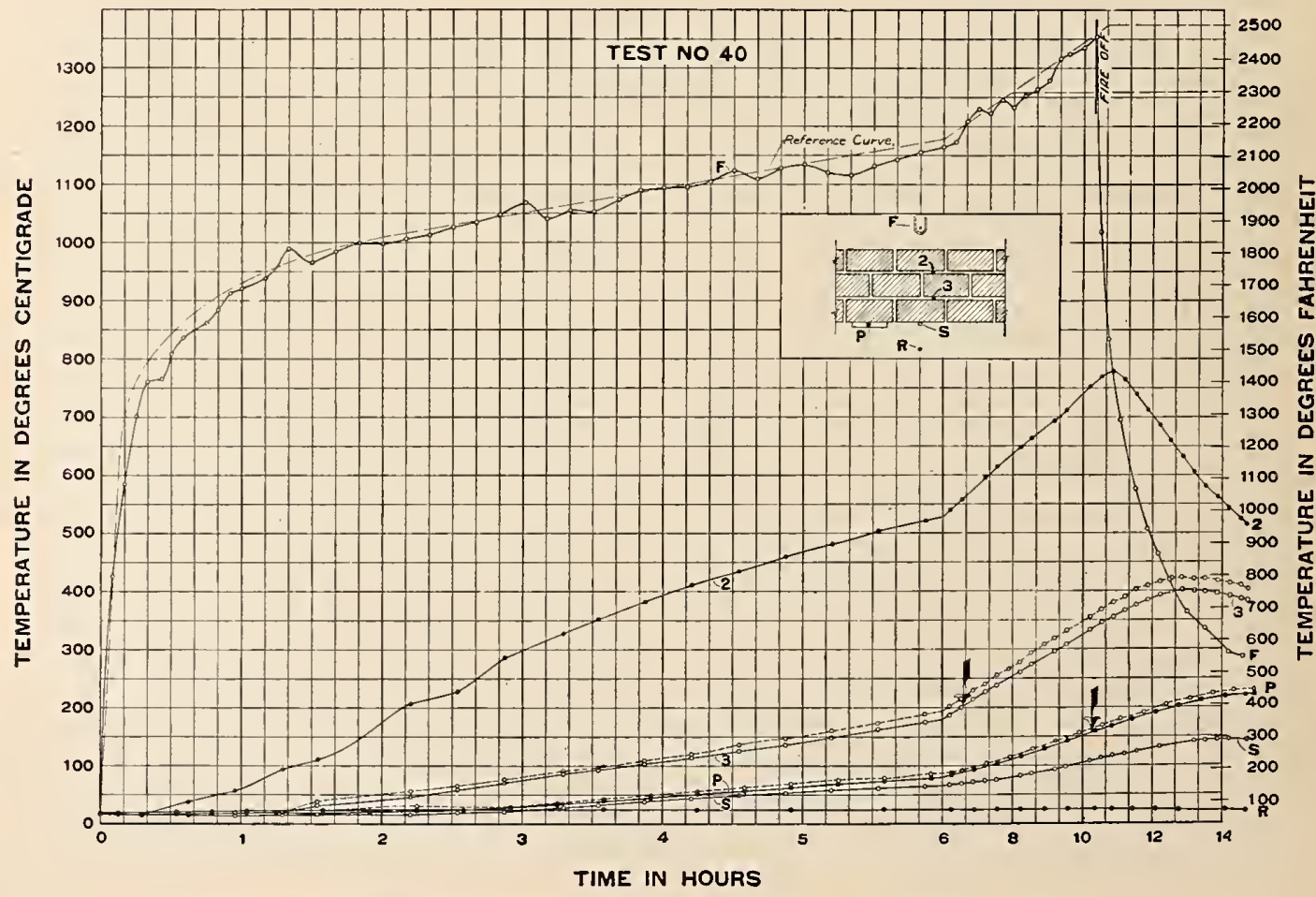

FigURe 25. Temperatures in fire-endurance test of 12-in. clay brick wall 40. 
FIGURE 26. L'nexposed side of 12-in. clay-brick wall 38 at the end of the fire-endurance lest.
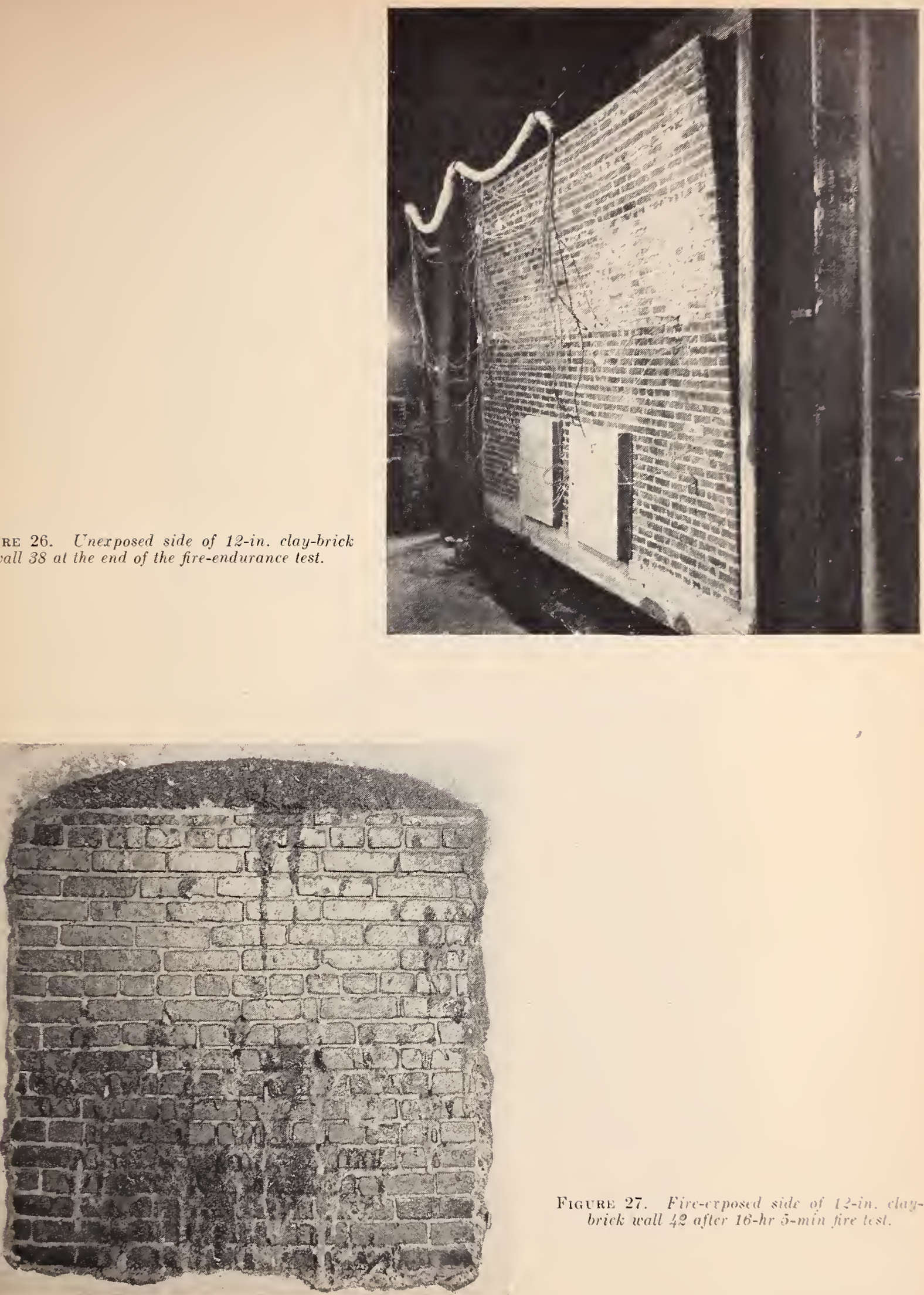

Figure 27. Fincerposed side of $1 ?-i n$. derybrick wall 40 after $16-h r$ jamin tire best. 
crete bricks from source COD, tested for $16 \mathrm{hr}$ $4 \mathrm{~min}$ and $12 \mathrm{hr} 30 \mathrm{~min}$, respectively, there was no general fluxing of the bricks. There was more fusion of the concrete top member of the loading frame (fig. 29). In the test of wall 49, most of the course on the fire-exposed side fused and flowed into the furnace pit. The bricks for these walls were from the same plant, but those for wall 49 were from a later delivery. There was also fusion of the fire-exposed course in the test of wall 50 of concrete bricks from source COE (fig. 30).

With walls of sand-lime bricks, the fusion effects were about the same as for concrete-brick walls tested for comparable durations.

In the tests of the longer durations, the mortar fused to depths up to 2 in. However, it remained largely in place where supported by bricks that had not fused.

It is to be noted that in these tests the furnace temperatures after $8 \mathrm{hr}$ ' were raised to a ceiling of 2,500 deg $\mathrm{F}$ at $10 \mathrm{hr} 40 \mathrm{~min}$. The prescribed procedure [6] was later revised so that the $2,300 \mathrm{deg} F$ reached at $8 \mathrm{hr}$ remained as the ceiling for tests of longer durations. Hence, according to the later procedure, there will be comparatively less fusion of wall materials in fire tests extending beyond 8 hr.

(6) Failure under load. The ability to carry the applied working load in tests of long duration was limited by fusion and decided loss in strength of brick and mortar in the course on the fireexposed side. The unexposed side of wall 44, of clay brick from source CLI, is shown in figure 31 after failure under load, and the fire-exposed side of sand-lime brick wall 52 is shown in figure 32 .

For 12-in. walls, the ability to carry load was determined with walls of the smaller size. It was deemed impractical to subject the large walls to fire tests of the required long durations, considering the damage and possible inoperative condition that would result for furnace and loading equipment. However, the size of wall specimen tested had a considerable bearing on the results obtained, due account of which will be taken in making the evaluation.

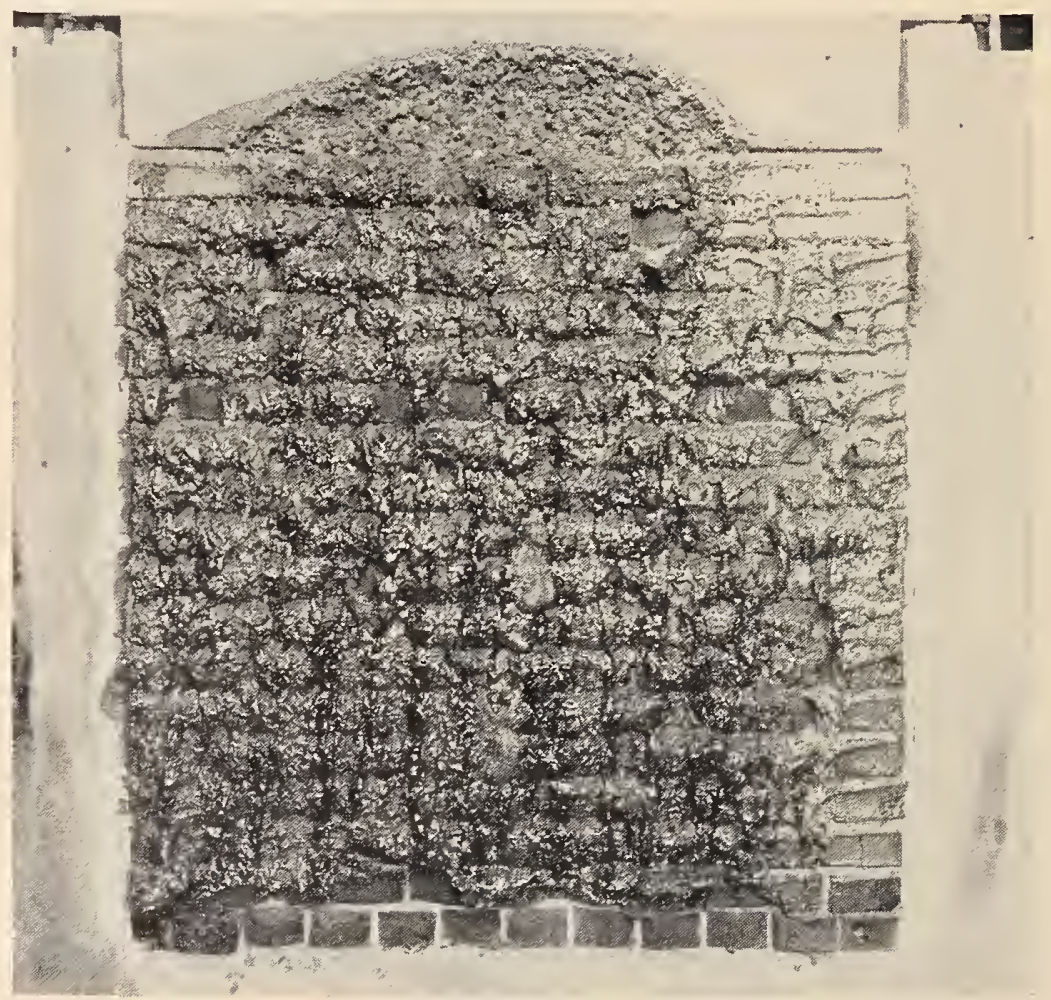

Figure 28. Fire-exposed side of 12-in. shale-brick wall 45 after 12-hr 50-min fire test. 


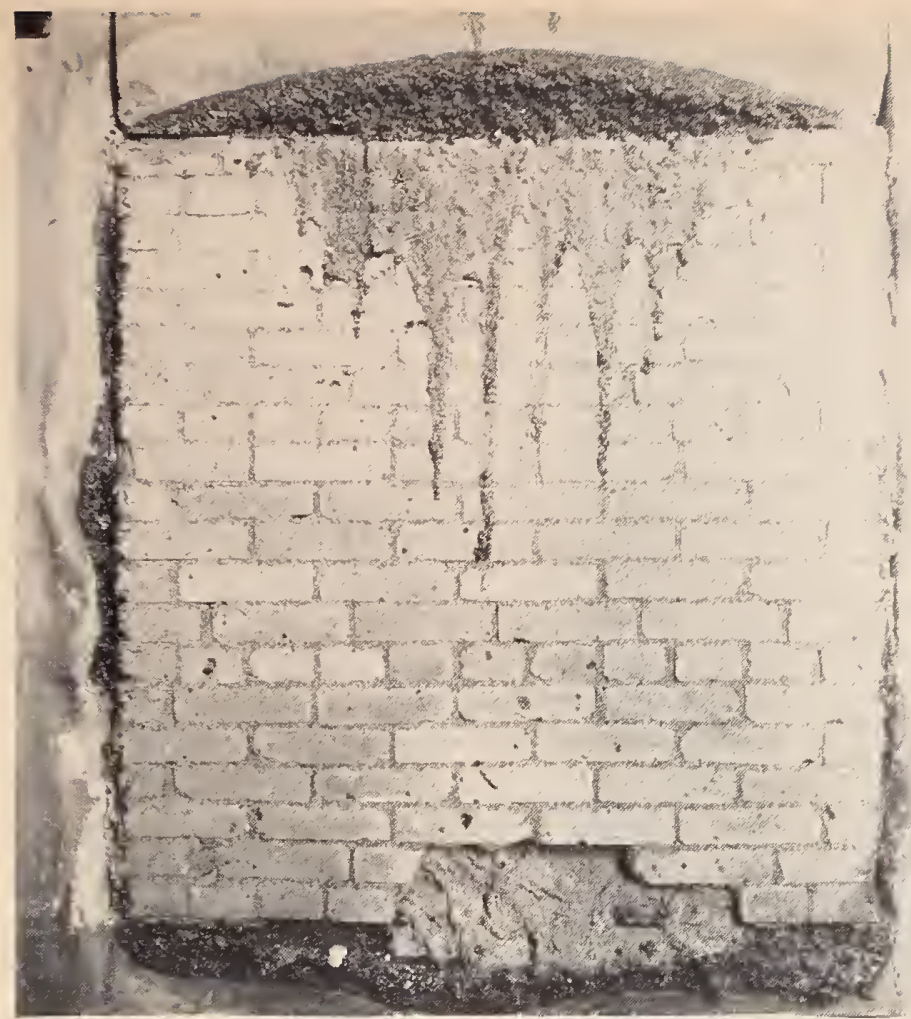

Figure 29. Fire-exposed side of 12-in. concrete-brick wall 47 after 16-hr 4-min fire test.

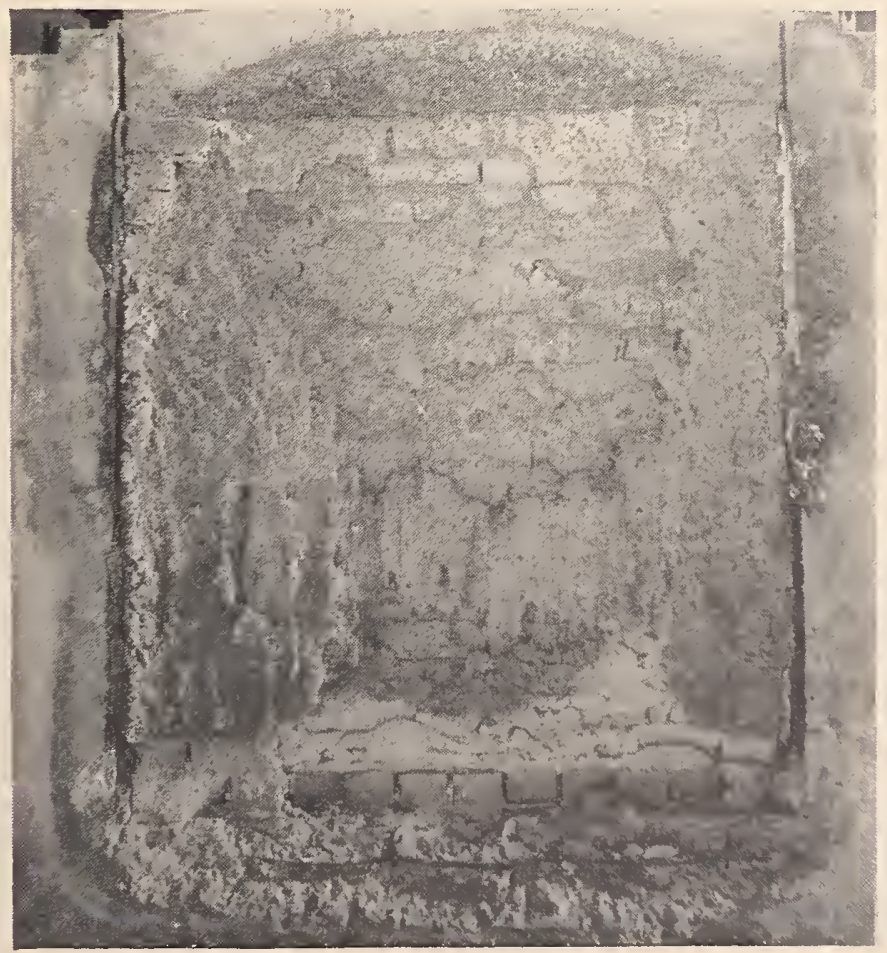

FIGURE 30. Fire-exposed side of 12-in. concrete-brick wall 50 after 14-hr fire test. 


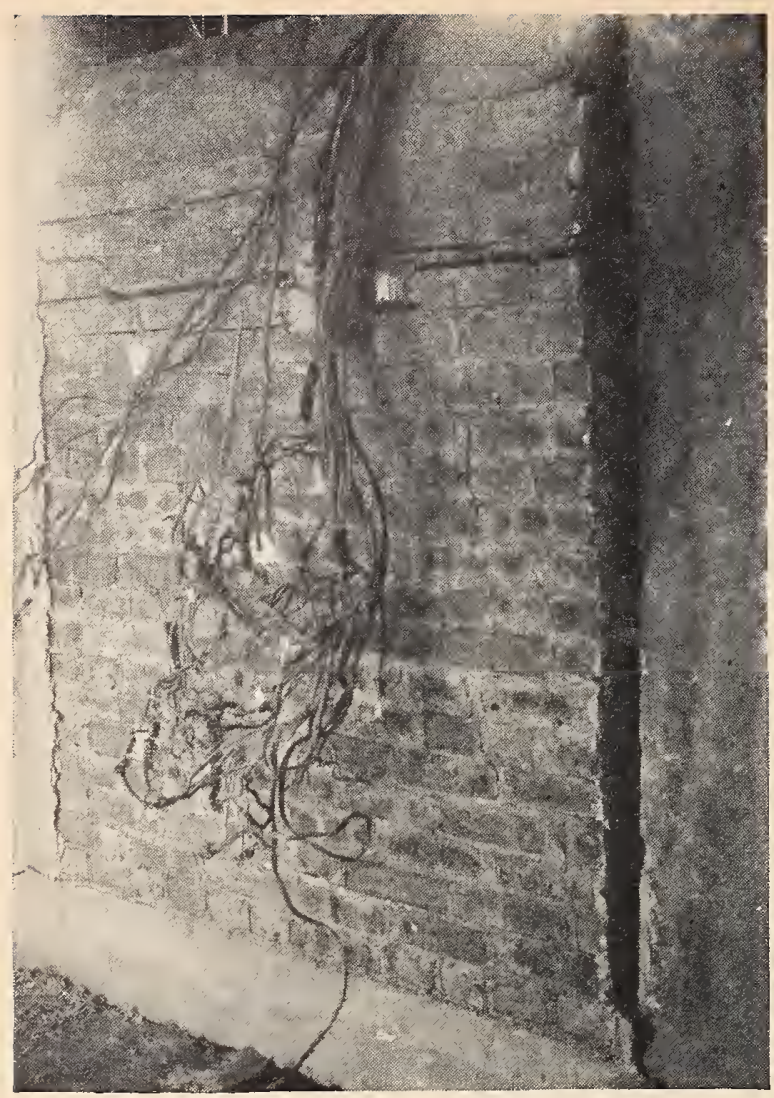

Figure 31. Unexposed side of 12-in. wall 44 of clay bricks from source CLI after failure under load at $10 \mathrm{hr} 21 \mathrm{~min}$ in fire-endurance test.

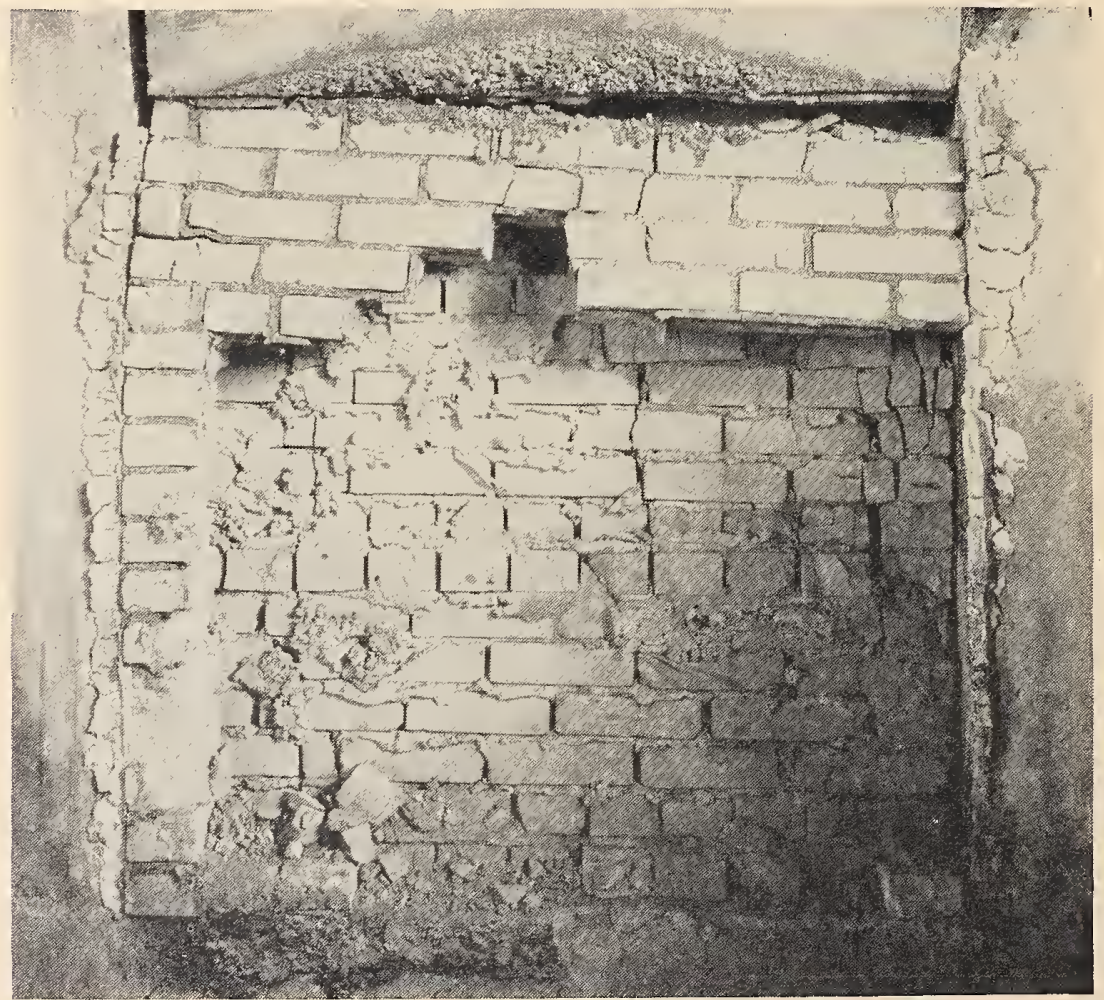

FIGURE 32. Fire-exposed side of 12-in. sand-lime brick wall 52 after failure under load at $9 \mathrm{hr} 57 \mathrm{~min}$ in fire-endurance test. 


\subsection{Results With Walls of Hollow Designs}

The schedule of tests with walls having one or more unfilled spaces in the wall thickness is given in table 7 , and the results of the tests in terins of fire-endurance limits are given in table 10. The walls were all built of clay or shale brick.

\section{a. Hollow Walls of 8-in. Thickness}

In this group are included 8 all-rolok walls (walls 54 to 61 ) and 2 (walls 62 and 63) of the rolok-bak pattern (fig. 1, designs D and E).

(1) Surface-temperature limits. The tests of all of the large walls (walls 54 to 59) were among the first in the series before surface temperatures were determined under the 0.40 -in.-thick asbestos pads. The time, however, at which an a rerage $250-\mathrm{deg}$ $F$ rise was reached on the free surface was determined in all of these tests. From these the approximate times for the rise under the asbestos pads, given in italies in table 10 , were derived by applring the 0.84 factor (section 4.1).

On this basis, the arerage time to reach the 250 -deg $F$ rise for the six unplastered walls, 54 to 59, was $2 \mathrm{hr} 46 \mathrm{~min}$. The minimum for any test was $2 \mathrm{hr} 25 \mathrm{~min}$. Typical time-temperature curves are given in figure 33.

These results might be considered qualified by lower limits indicated over cracks for walls 57 , 58, and 59. The hot spots were actually over holes in the rertical mortar joints, which were not as well filled for bricks set with the 4-in. dimensions rertically as for the conventional method with bricks laid flatwise. This was due in part to less experience of the masons with this method and also less care in pointing of joints than would be required for unplastered walls in building construction.

The occurrence for wall 58 of the limiting temperature rise at $2 \mathrm{hr} 14 \mathrm{~min}$ under the 3 - by 3 - $\mathrm{ft}$ cotton pad of $3 \frac{1}{2}-$ in. thickness can be taken as due largely to the greater heat insulation over the area adjacent to the thermocouple as compared with that given by 6 - by 6 -in. asbestos pads of 0.40 -in. thickness.

With all-rolok walls 60 and 61 plastered on both sides, the limit of average temperature rise on the unexposed surface was reached soon after $5 \mathrm{hr}$. These tests were with walls of the smaller size, and considering the air space, the results may have been unduly affected by cooling from the borders.

Talls 62 and 63 were of the rolok-bak design with bricks laid flat for the face course and on edge for the backing (fig. 1-E), the backing as plastered being exposed to the furnace fire. For wall 62 , the limit of surface-temperature rise came at $4 \mathrm{hr} 58 \mathrm{~min}$ (fig. 34) and for wall 63 at 4 $\mathrm{hr}$, all lime plaster on the latter falling off during the first $15 \mathrm{~min}$ of the test. The gypsum plaster on wall 62 remained in place for $2 \mathrm{hr}$, but at $4 \frac{1}{2}$ $\mathrm{hr}$ practically all had fallen off. For these walls also the results may be subject to qualification due to eooling from the borders, considering the continuous air space between the faring and barking.

(2) Temperature limits in wall. "The limiting temperature rise in the wall, as given in the last columns of table 10 , is taken at 250 deg $F$ for the average and $325 \mathrm{deg} F$ at any thernocouple location. This is lower than the comparable limits for solid wall constructions (table 9) because parts of combustible members projecting into the air space ignite and burn more readily than those embedded in a solid wall.

The average time for the present limit in tests of unplastered 8-in. rolok walls was $1 \mathrm{hr}$, with minimum in any test of $54 \mathrm{~min}$. For the two plastered walls, 60 and 61 , the average was $1 \mathrm{hr}$ $42 \mathrm{~min}$.

(3) Restraint, loading, and lateral deflections. Of the 6 large 8 -in. all-rolok walls, 2 were tested restrained within the panel frame and 3 unrestrained. One of shale bricks was tested under load of $160 \mathrm{lb} / \mathrm{in}^{2}{ }^{2}$ of gross area, which was sustained throughout a 6-hr fire test (fig. 3.5).

As for solid walls, the lateral deflection as tested restrained was indicated as greater than with the wall under load (fig. 36). The deflection at the top of unrestrained walls was 2 to 4 times the center deflection of restrained or loaded walls, the relation boing less consistent than in tests with solid walls. There was no collapse due to deflection with walls of $11-\mathrm{ft}$ height and exposed to fire for periods considerably beyond their fireendurance limits as determined by the temperature rise on the unexposed side.

(4) Cracks and other fire effects. For walls tested restrained, the cracks were hardly noticeable, and between wall and frame there were openings on the unexposed side up to $1 / 4 \mathrm{in}$. In the wall tested under load, cracks opened up to $1 / 8 \mathrm{in}$., and in those tested unrestrained, up to $3 / 16$ in. These were generally inclined and through the mortar joints.

The fusion effects with walls of clay bricks from source CLI, tested for $6 \mathrm{hr}$, were about the same as for solid walls of bricks from the same sourec (fig. 16). However, there was no fusion of bricks from this source in a wall exposed to fire for nearly4 hr (fig. 37).

\section{b. Hollow Walls of 12-in. thickness}

This group comprises six walls, 64 to 69 of several rolok designs (fig. $1, \mathrm{~F}$ to $\mathrm{K}$ ). They were all built of clay brieks from source CL, I.

(1) Surface-temperature limit.. In the test of all-rolok wall 64, the temporiture-rise limit was not reached, but with wall 65 of altomato rolok design, the 250-deg F rise under the ashestos paul eame at 5 he 7 min (fig. 3s). For wall tit of the flat-bond rolok design and plistered on both sides. the limit was reached at 10 ho 12 111ur, this result being apparently aflected by cooling from the borders through the continumus a ir spile'es. 'The sin mo' applies, although possibly in liss cherreos to the 
TABLE 10. Results of fire-endurance tests of hollow walls of clay or shale brick

Walls having minimum lateral dimension of $10 \mathrm{ft}$ and area of $100 \mathrm{ft}^{2}$ conform to present requirements of ASTM Standard E119

\begin{tabular}{|c|c|c|c|c|c|c|c|c|c|c|c|c|}
\hline \multirow{2}{*}{$\begin{array}{l}\text { Wall } \\
\text { or test }\end{array}$} & \multirow{2}{*}{$\begin{array}{l}\text { Nominal } \\
\text { thick- } \\
\text { ness }\end{array}$} & \multirow{2}{*}{$\begin{array}{l}\text { Wall } \\
\text { area }\end{array}$} & \multirow{2}{*}{$\begin{array}{l}\text { Wall design } \\
\text { (fig. No.) }\end{array}$} & \multirow{2}{*}{$\begin{array}{l}\text { Brick } \\
\text { symbol }\end{array}$} & \multicolumn{2}{|c|}{ Plaster } & \multirow{2}{*}{$\begin{array}{l}\text { Restraint or } \\
\text { loading } \\
\text { during test }\end{array}$} & \multirow{2}{*}{$\begin{array}{l}\text { Age at } \\
\text { time } \\
\text { of test }\end{array}$} & \multirow{2}{*}{\multicolumn{2}{|c|}{ Duration }} & \multirow{2}{*}{ Why ended } & \multirow{2}{*}{$\begin{array}{l}\text { Severity } \\
\text { of furnace } \\
\text { exposure }\end{array}$} \\
\hline & & & & & $\begin{array}{c}\text { Fire-ex- } \\
\text { posed side }\end{array}$ & $\begin{array}{c}\text { Unexposed } \\
\text { side }\end{array}$ & & & & & & \\
\hline $\begin{array}{l}54 \\
55\end{array}$ & $\begin{array}{r}\text { in. } \\
8 \\
8\end{array}$ & $\begin{array}{l}f t^{2} \\
171 \\
171\end{array}$ & $\begin{array}{l}\text { All-rolok 1-D } \\
\text { do }\end{array}$ & $\underset{\mathrm{CLI}}{\mathrm{CLM}}$ & $\begin{array}{l}\text { None } . . \\
\text {. do }\end{array}$ & $\begin{array}{l}\text { None } \\
\text {. do }\end{array}$ & $\begin{array}{l}\text { Unrestrained } \\
\text { do }\end{array}$ & $\begin{array}{r}\text { Days } \\
40 \\
34\end{array}$ & $\begin{array}{r}h r \\
6 \\
3\end{array}$ & $\begin{array}{c}\min \\
1 \\
58\end{array}$ & $\begin{array}{l}\text { Set limit } \\
\text { High wall tem- }\end{array}$ & $\begin{array}{c}\text { Percent } \\
101: 2 \\
101.0\end{array}$ \\
\hline $\begin{array}{l}56 \\
57 \\
58\end{array}$ & $\begin{array}{l}8 \\
8 \\
8\end{array}$ & $\begin{array}{l}176 \\
176 \\
171\end{array}$ & $\begin{array}{l}\text { _. do do } \\
\\
\end{array}$ & $\begin{array}{l}\text { CLI } \\
\text { CLI } \\
\text { SHW }\end{array}$ & $\begin{array}{r}\text { do } \\
\hdashline \text { do } \\
\hdashline \text { do }\end{array}$ & $\begin{array}{c}\text { do } \\
\text { do } \\
\text { do }\end{array}$ & $\begin{array}{l}\text { Restrained } \\
\text { Unrestrained }\end{array}$ & $\begin{array}{l}38 \\
40 \\
53\end{array}$ & $\begin{array}{l}6 \\
6 \\
6\end{array}$ & $\begin{array}{l}1 \\
1 \\
1\end{array}$ & $\begin{array}{c}\text { perature. } \\
\text { Set limit } \\
\text { do }\end{array}$ & $\begin{array}{l}98.0 \\
99.2 \\
99.9\end{array}$ \\
\hline $\begin{array}{l}59 \\
60\end{array}$ & $\begin{array}{l}8 \\
8\end{array}$ & $\begin{array}{l}163 \\
17.4\end{array}$ & $\begin{array}{l}\text { do... do } \\
\text { do }\end{array}$ & $\begin{array}{l}\text { SHW } \\
\text { CLM }\end{array}$ & Lime. & Lime & $\begin{array}{l}160 \mathrm{lb} / \mathrm{in} .^{2} \\
\text { Restrained }\end{array}$ & $\begin{array}{l}32 \\
42\end{array}$ & $\begin{array}{l}6 \\
8\end{array}$ & $\begin{array}{l}0 \\
0\end{array}$ & High wall tem- & $\begin{array}{r}100.2 \\
99.2\end{array}$ \\
\hline $\begin{array}{l}61 \\
62 \\
63\end{array}$ & $\begin{array}{l}8 \\
8 \\
8\end{array}$ & $\begin{array}{l}17.4 \\
16.7 \\
16.7\end{array}$ & Rolok-bak 1-E & $\begin{array}{l}\text { CLM } \\
\text { CLM } \\
\text { CLM }\end{array}$ & $\begin{array}{l}\text { Gypsum } \\
\text { Lime } \\
\text { Lime }\end{array}$ & $\begin{array}{l}\text { Gypsum. } \\
\text { None } . . . \\
\text { do }\end{array}$ & $160 \mathrm{lb} / \mathrm{in} \mathrm{r}^{2}$ & $\begin{array}{l}45 \\
43 \\
46\end{array}$ & $\begin{array}{l}6 \\
6 \\
5\end{array}$ & $\begin{array}{r}1 \\
20 \\
30\end{array}$ & \begin{tabular}{c} 
perature. \\
\hdashline$\quad$ do \\
\hdashline do
\end{tabular} & $\begin{array}{l}98.7 \\
99.4 \\
98.4\end{array}$ \\
\hline 64 & 12 & 171 & All-rolok 1-F. & CLMI & None & _...do & Unrestrained & 100 & 5 & 13 & Equipment fail- & 98.2 \\
\hline 65 & 12 & 17.4 & Rolok $1-G_{-}$ & CLM & . do do. & do .. & Restrained... & 47 & 8 & 0 & $\begin{array}{l}\text { ure: } \\
\text { High wall tem- }\end{array}$ & 98.3 \\
\hline $\begin{array}{l}66 \\
67\end{array}$ & $\begin{array}{l}12 \\
12\end{array}$ & $\begin{array}{l}17.4 \\
17.4\end{array}$ & Rolok 1-H & $\begin{array}{l}\text { CLM } \\
\text { CLM }\end{array}$ & $\begin{array}{l}\text { Gypsum } \\
\text { do }\end{array}$ & $\begin{array}{l}\text { Gypsum } \\
\text { - do }\end{array}$ & _ do & $\begin{array}{l}46 \\
46\end{array}$ & $\begin{array}{r}8 \\
10\end{array}$ & $\begin{array}{r}0 \\
50\end{array}$ & $\begin{array}{l}\text { perature. } \\
\text { Set limit } \\
\text { High wall tem- }\end{array}$ & $\begin{array}{l}100.1 \\
100.1\end{array}$ \\
\hline 68 & 12 & 16.7 & Rolok-bak 1-J... & C LM & None. & None - & Unrestrained & 41 & 12 & 20 & perature. & 102.1 \\
\hline $\begin{array}{l}69 \\
70 \\
71\end{array}$ & $\begin{array}{l}12 \\
10 \\
10\end{array}$ & $\begin{array}{l}16.7 \\
163 \\
164\end{array}$ & $\begin{array}{l}\text { Rolok-faced 1-K. } \\
\text { Cavity 1-L_ }\end{array}$ & $\begin{array}{l}\text { CLM } \\
\text { CLN } \\
\text { CLN }\end{array}$ & $\begin{array}{l}\text { do } \\
\ldots \text { do } \\
\text { do }_{2}\end{array}$ & $\begin{array}{l}\text { do } \\
\text { do } \\
\text { do.. }\end{array}$ & $\begin{array}{l}160 \mathrm{lb} / \mathrm{in} .^{2} \\
125 \mathrm{lb} / \mathrm{in}^{2} \\
54 \mathrm{lb} / \mathrm{in} .^{2}-\ldots\end{array}$ & $\begin{array}{l}41 \\
48 \\
33\end{array}$ & $\begin{array}{r}10 \\
1 \\
5\end{array}$ & $\begin{array}{r}1 \\
17 \\
18\end{array}$ & $\begin{array}{l}\text { Wall collapsed. } \\
\text { High wall tem- }\end{array}$ & $\begin{array}{l}100.1 \\
101.5 \\
100.0\end{array}$ \\
\hline 72 & 10 & 160 & _... do & $\mathrm{CLN}$ & _._do & ... do _. & Restrained _. & 41 & 5 & 3 & $\begin{array}{c}\text { perature. } \\
\end{array}$ & 100.0 \\
\hline
\end{tabular}

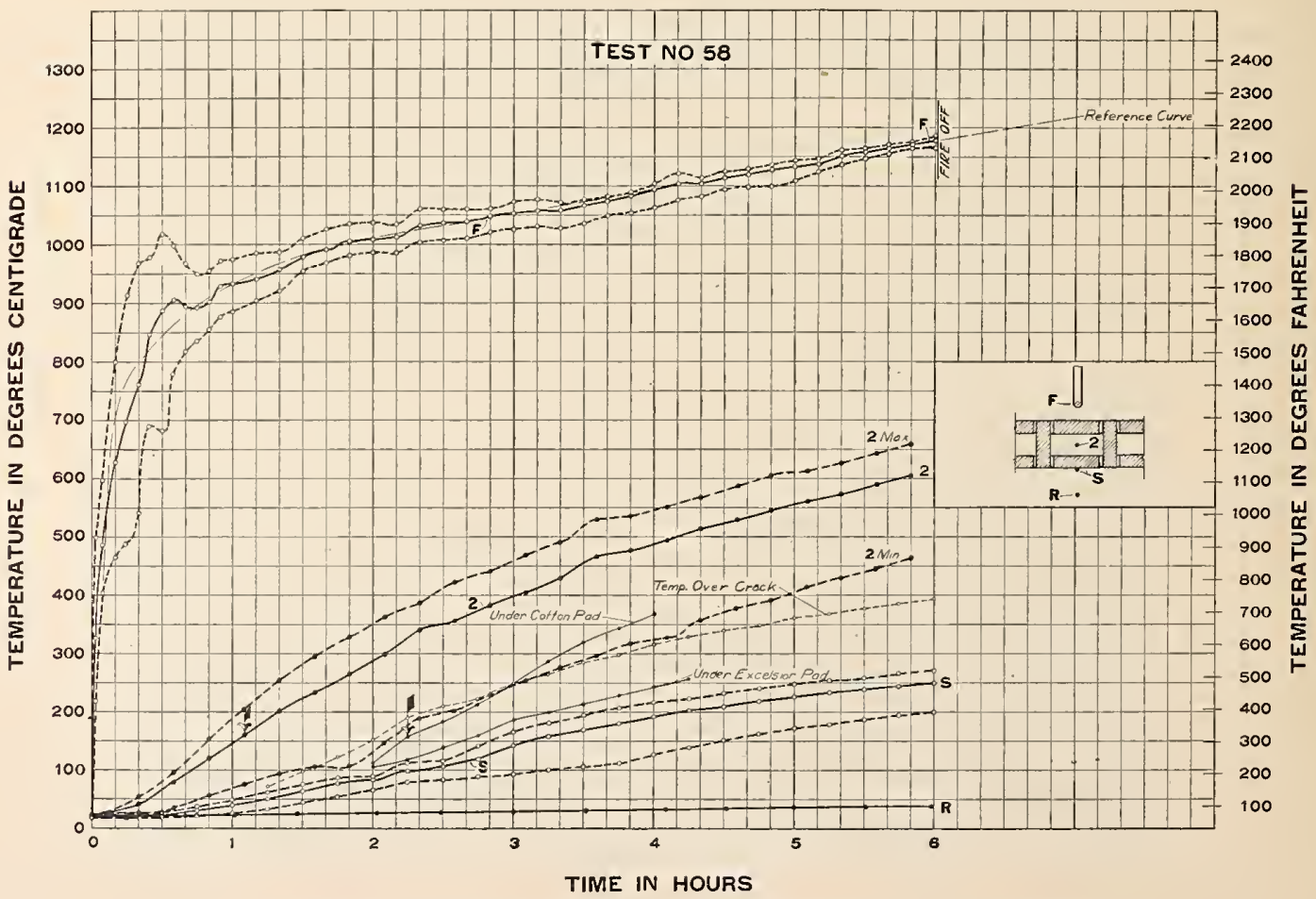

FIgure 33. Temperatures in fire-endurance lest of 8-in. all-rolok wall 58. 
TABLE 10. Results of fire-endurance tests of hollow walls of clay or shale brich.-Continued

\begin{tabular}{|c|c|c|c|c|c|c|c|c|c|c|c|}
\hline \multirow{3}{*}{$\begin{array}{c}\text { Wall or } \\
\text { test }\end{array}$} & \multicolumn{9}{|c|}{ Temperature rise at unexposed surface } & \multirow{2}{*}{\multicolumn{2}{|c|}{$\begin{array}{l}\text { Time of temperatire } \\
\text { rise in wall } 4 \text { Ln. from } \\
\text { unexposed surface }\end{array}$}} \\
\hline & \multicolumn{2}{|c|}{ A rerage at end of test } & \multicolumn{4}{|c|}{ Time of average 250 -deg $\mathrm{F}$ rise } & \multicolumn{3}{|c|}{ 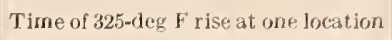 } & & \\
\hline & $\begin{array}{c}\text { Asbestos } \\
\text { pad }\end{array}$ & $\begin{array}{c}\text { Free } \\
\text { surface }\end{array}$ & $\begin{array}{c}\text { Asbestos } \\
\text { pad }\end{array}$ & $\begin{array}{c}\text { Free } \\
\text { surfaee }\end{array}$ & $\begin{array}{l}\text { Cotton } \\
\text { pad }\end{array}$ & $\begin{array}{l}\text { Exeelsior } \\
\text { box }\end{array}$ & $\begin{array}{c}\text { Ashestos } \\
\text { pad }\end{array}$ & $\begin{array}{c}\text { Free } \\
\text { surface }\end{array}$ & $\begin{array}{l}\text { Over } \\
\text { crack }\end{array}$ & $\begin{array}{l}\text { 25(0)-rleg } F \\
\text { average }\end{array}$ & $\begin{array}{l}\text { 32irlf:g F } \\
\text { maximum }\end{array}$ \\
\hline $\begin{array}{l}54 \\
55\end{array}$ & ${ }^{\circ} F$ & $\begin{array}{c}{ }^{\circ} F \\
-\cdots\end{array}$ & $\begin{array}{ll}\text { hr } & \min \\
12 & 25 \\
.2 & 45\end{array}$ & $\begin{array}{rl}h r & \min \\
2 & 52 \\
3 & 16\end{array}$ & hr min & $\begin{array}{c}\text { hr min } \\
-\end{array}$ & $h r \min$ & $\begin{array}{rl}\text { hr } & \min \\
3 & 24 \\
3 & 42\end{array}$ & hr min & $\begin{array}{cc}\text { hr } & \min \\
0 & 54 \\
1 & 0\end{array}$ & $\begin{array}{cl}\text { hr } & \min \\
0 & 57 \\
1 & 10\end{array}$ \\
\hline $\begin{array}{l}56 \\
57 \\
58\end{array}$ & - & $\begin{array}{l}379 \\
410 \\
420\end{array}$ & $\begin{array}{ll}2 & 55 \\
2 & 37 \\
2 & 42\end{array}$ & $\begin{array}{rr}3 & 29 \\
3 & 7 \\
3 & 13\end{array}$ & 214 & $2^{42}$ & (n) & $\begin{array}{ll}4 & 25 \\
3 & 49 \\
3 & 33\end{array}$ & $\begin{array}{rr}21 & 47 \\
2 & 21\end{array}$ & $\begin{array}{rr}1 & 4 \\
0 & 56 \\
1 & 5\end{array}$ & $\begin{array}{rr}1 & 10 \\
1 & 2 \\
1 & 5\end{array}$ \\
\hline $\begin{array}{l}59 \\
60\end{array}$ & 500 & $\begin{array}{l}390 \\
315\end{array}$ & $\begin{array}{rr}3 & 13 \\
5 & 2\end{array}$ & $\begin{array}{rr}3 & 50 \\
6 & 7\end{array}$ & $\begin{array}{ll}2 & 57\end{array}$ & $\begin{array}{ll}4 \quad 2 \\
\end{array}$ & - & $\begin{array}{ll}4 & 15 \\
7 & 26\end{array}$ & $\begin{array}{l}22 \quad 07 \\
-\end{array}$ & $\begin{array}{ll}0 & 59 \\
1 & 45\end{array}$ & $\begin{array}{ll}1 & 05 \\
1 & 51\end{array}$ \\
\hline $\begin{array}{l}61 \\
62 \\
63\end{array}$ & $\begin{array}{l}343 \\
414 \\
447\end{array}$ & $\begin{array}{l}253 \\
234 \\
277\end{array}$ & $\begin{array}{rr}5 & 13 \\
4 & 58 \\
4 & 0\end{array}$ & $\begin{array}{ll}5 & 57 \\
\mathrm{nr}^{5} & 08\end{array}$ & - & (n) & (n) & ${ }_{3}^{3} \mathrm{nr}$ & (n) & $\begin{array}{ll}1 & 39 \\
1 & 52 \\
0 & 57\end{array}$ & $\begin{array}{rr}1 & 55 \\
1 & 37 \\
1 & 0\end{array}$ \\
\hline 64 & - & 114 & . & $\mathrm{nr}$ & $\mathrm{nr}$ & nr & & $\mathrm{nr}$ & $\left(\begin{array}{ll}5 & 32\end{array}\right)$ & 341 & 248 \\
\hline 65 & 462 & 281 & 57 & 75 & - & - & -...... & $7 \quad 47$ & - - & 245 & 241 \\
\hline $\begin{array}{l}66 \\
67\end{array}$ & $\begin{array}{l}166 \\
320\end{array}$ & $\begin{array}{l}130 \\
219\end{array}$ & $\begin{array}{cc}\left(\begin{array}{rr}9 & 7\end{array}\right) \\
10 & 12\end{array}$ & $\left.{ }_{\left(11^{n}\right.}{ }^{\mathrm{nr}}\right)$ & - & - & - & $\begin{array}{l}\mathrm{nr} \\
\mathrm{nr}\end{array}$ & - & $\begin{array}{rr}4 & 7 \\
5 & 20\end{array}$ & $\begin{array}{ll}3 & 47 \\
5 & 31\end{array}$ \\
\hline 68 & 359 & 260 & $10 \quad 42$ & 122 & -- & -- & - & $\mathrm{nr}$ & $-\cdots$ & 456 & $4 \quad 4.5$ \\
\hline $\begin{array}{l}69 \\
70 \\
71\end{array}$ & $\begin{array}{r}359 \\
17 \\
252\end{array}$ & 218 & $\begin{array}{l}8 \quad 52 \\
\mathrm{nr}_{5} \quad 17\end{array}$ & nr & $-\cdots$ & - & $\begin{array}{l}\mathrm{nr} \\
\mathrm{nr}\end{array}$ & nr & - & $\begin{array}{l}4 \quad 58 \\
\operatorname{nr}^{4} 48\end{array}$ & $\begin{array}{l}5 \quad 28 \\
2^{\mathrm{nr}}\end{array}$ \\
\hline 72 & 264 & -....- & $4 \quad 56$ & - - - - - & . & - . - & $\mathrm{nr}$ & ......... & ......... & 125 & 128 \\
\hline
\end{tabular}

1 Figures in italics indicate derived temperature limit for determination under ashestos pads (see section $6.1, a$ ).

2 Cotton waste placed orer thermocouple.

" "nr" indicates that a given temperature was not reached.

- Figures in parentheses indicate temperature rise reached after the test fire was shut off.

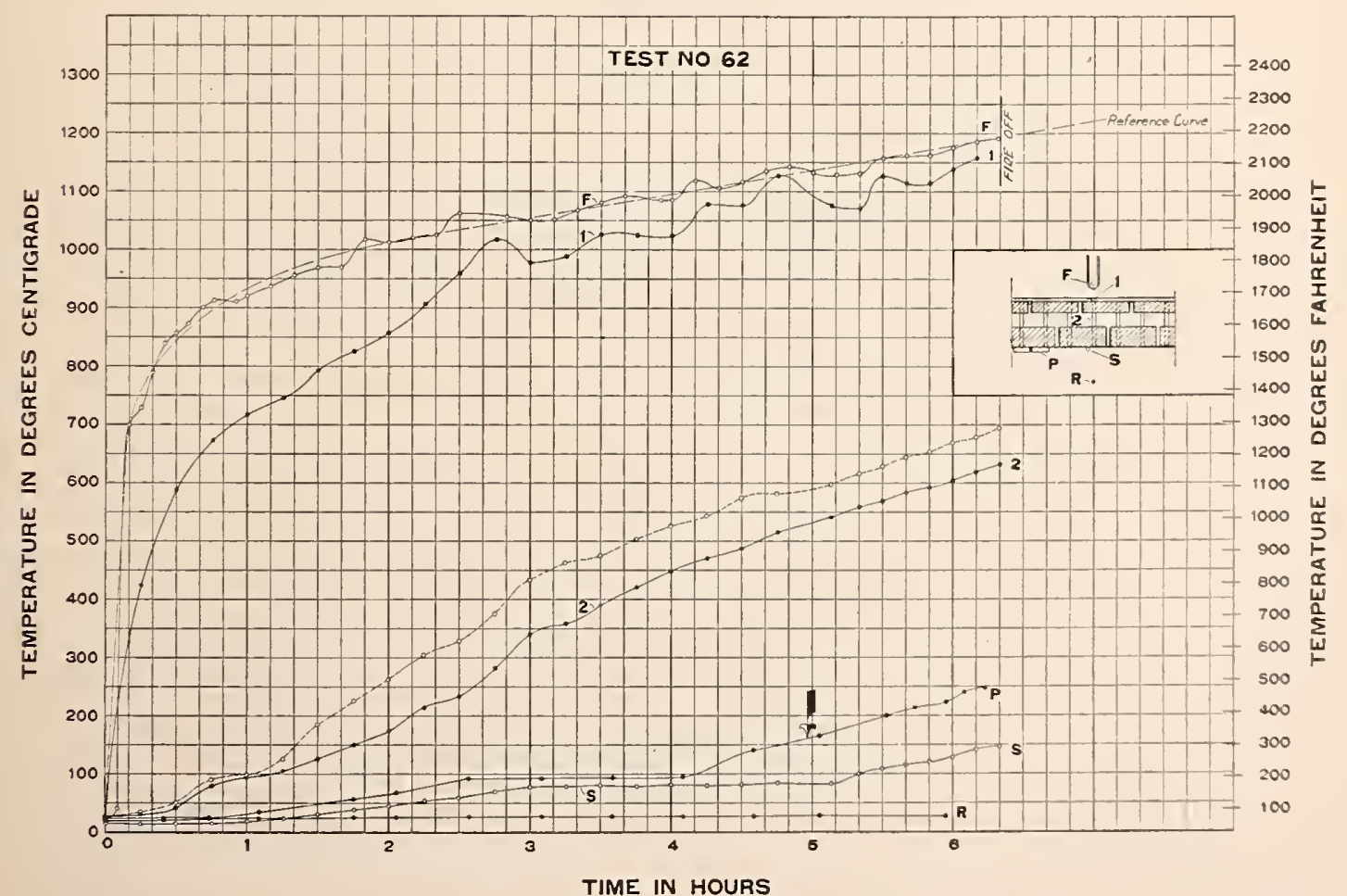

FIGURE 34. Temperatures in fire-enduranee test of 8 -in. rolok-bak wall 6., plasterd on the fire-irposid side. 


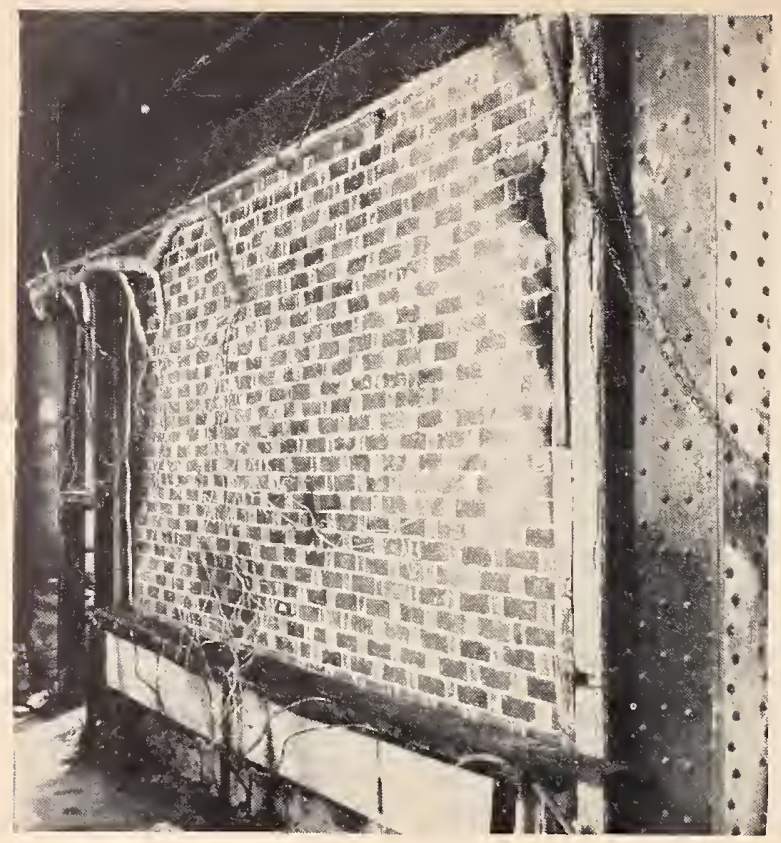

Figure 35. Unexposed side of 8-in. all-rolok wall 59 after 6 - $\mathrm{hr}$ fire test under load of $160 \mathrm{lb} / \mathrm{in},{ }^{2}$ of gross area.

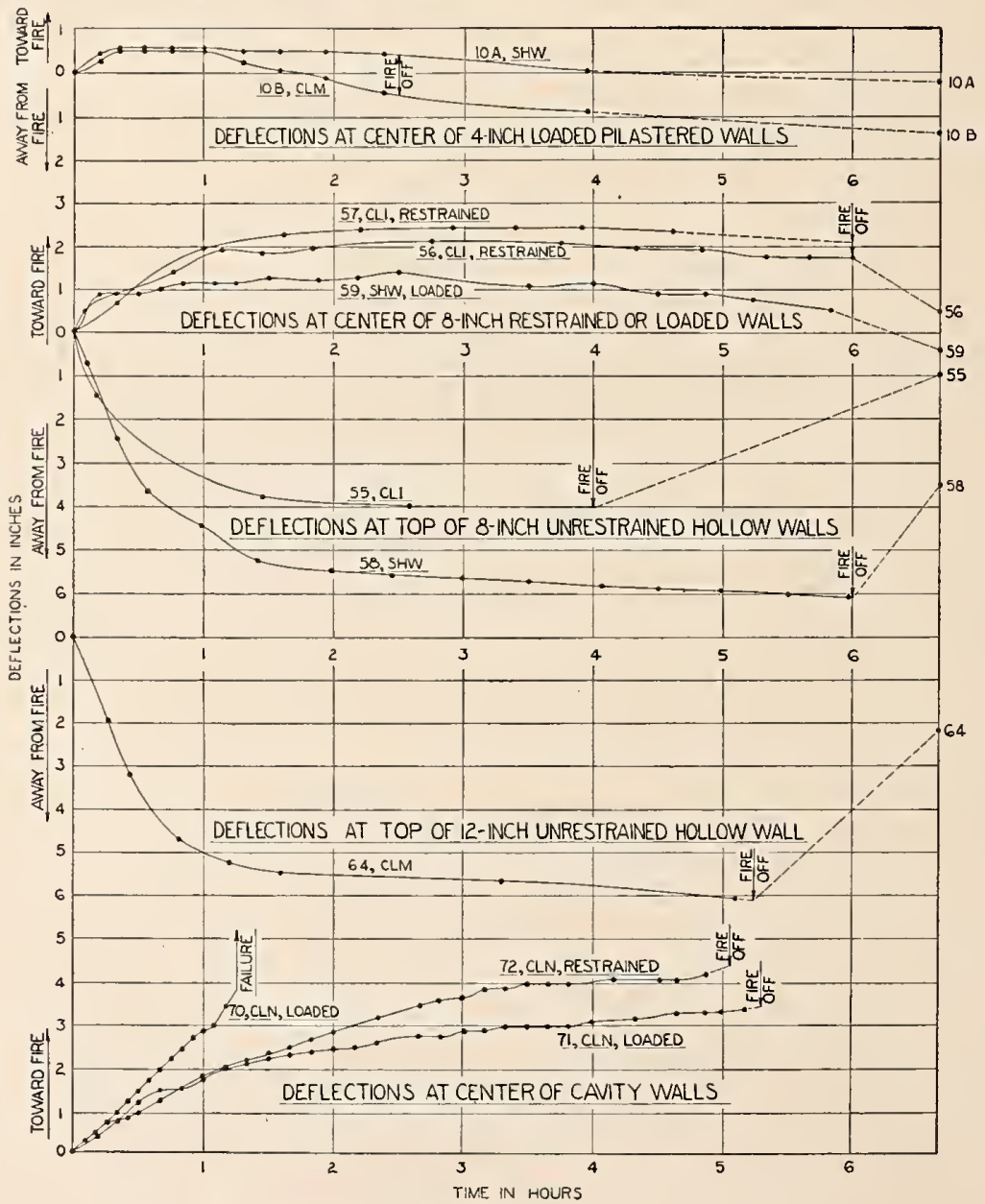

Figure 36. Deflections of hollow walls of clay and shale bricks. 


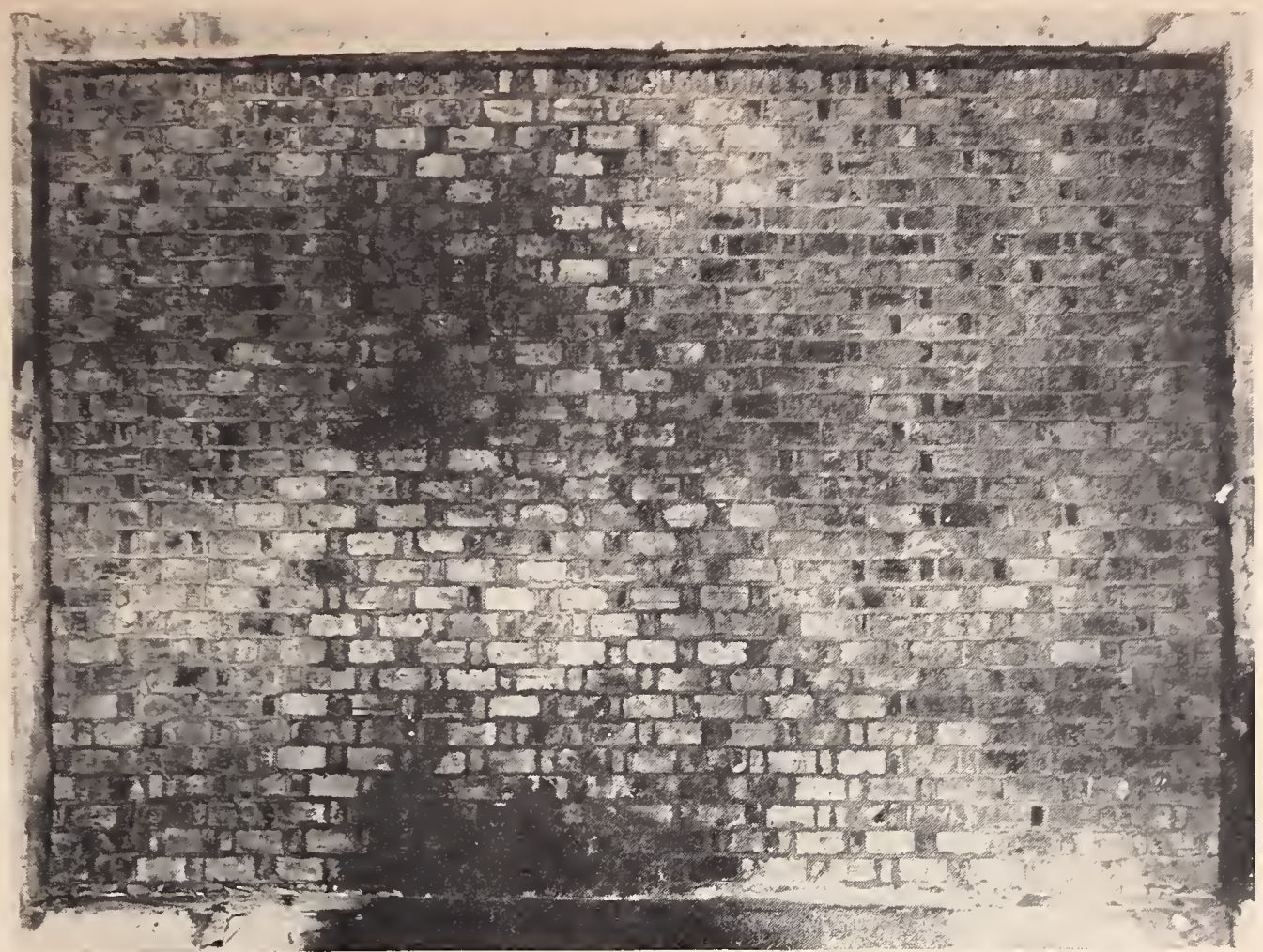

FIGURE 37. Fire-exposed side of 8-in. all-rolok wall 55, of clay bricks from source CLI, after 3-hr 58-min fire exposure.

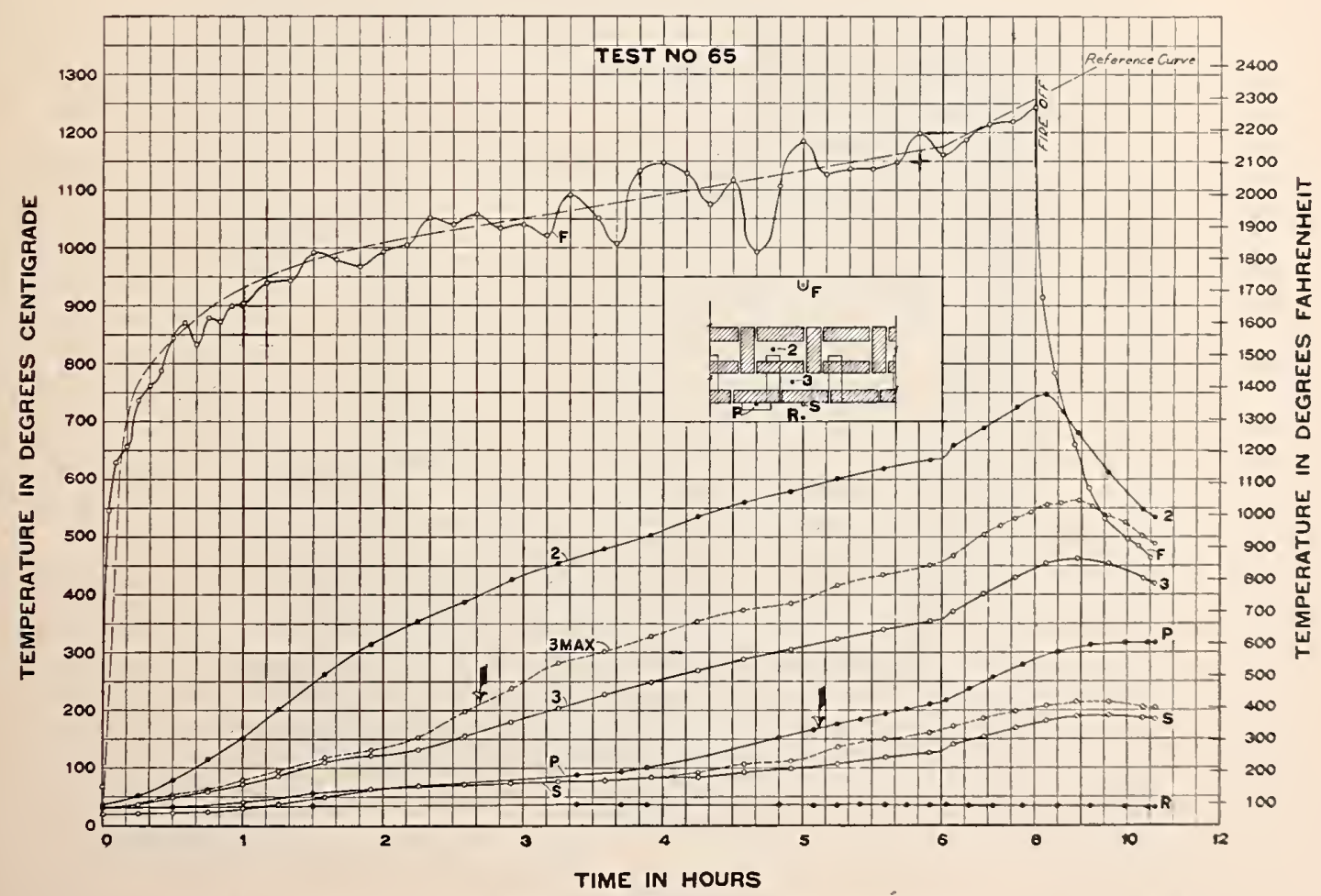

FIGURE 38. Temperatures in fire-endurance test of 12-in. wall 65 of allernate rolok design. 
10-hr 42-min limit for rolok-bak wall 68 and the 8-hr 52-min limit for rolok-faced wall 69.

(2) Temperature limits in wall. The times when an average temperature rise of 250 -deg F occurred in the air space next to the unexposed side or a rise of 325 deg $\mathrm{F}$ at any thermocouple location, are given in the last two columns of table 10 . As for surface-temperature limits, the results with the small walls, and particularly with those of the flat-bond rolok and rolok-faced designs, are subject to qualification because of cooling from the borders through continuous unobstructed air spaces.

(3) Cracks and other fire effects. In none of the tests was cracks noted that would affect the fire resistance of these 12 -in. walls. The top of wall 64 , tested unrestrained, deflected outward about 6 in. (fig. 36).

The walls were built of brick from source CLMI, showing a relatively high softening point, and there was no fusion causing flow of brick material. Figure 39 shows the fire-exposed face of wall 67 of the flat-bond rolok design after 10-hr 50-min fire exposure. The plaster had fallen from the fire-exposed side during the first $2 \mathrm{hr}$ of the test. In figure 40, showing the backing side of rolokbak wall 68 fire-exposed for 12 hr 20 min, fusion and flow of mortar is seen in joints between bricks set on edge, but none in the brick material.

\section{c. Cavity Walls}

Three fire tests were conducted with cavity-type walls (fig. 1-L), consisting of two brick wythes with a 2 -in. air space between them, spanned by Z-shaped wire ties. They were built of clay brick from source CLN laid up in 1:1:6 cement-limesand mortar. As the width of the bricks was little more than $3 \frac{1}{2}$ in., the actual thickness of the walls was in the range $9 \frac{1}{4}$ to $91 / 2$ in.

(1) Temperature-rise limits. The time at which an average rise of $250-\mathrm{deg} \mathrm{F}$ was reached under the asbestos pads was 5 hr 6 min, taken as an average for walls 71 and 72 . The time-temperature curves for the former are given in figure 41 .

For the same walls, the 250 -deg $F$ rise in the air space was reached in an average time of $1 \mathrm{hr} 36$ min. However, wood joists usually project into walls no more than $3 \frac{1}{2} \mathrm{in}$. for bearing purposes and would be almost embedded. Accordingly, the permissible average rise of $325-\mathrm{deg} \mathrm{F}$, same as for solid walls, might apply, which rise was reached in $2 \mathrm{hr} 10 \mathrm{~min}$ and $1 \mathrm{hr} 43 \mathrm{~min}$, respectively, for the two walls, or an average time of $1 \mathrm{hr} 56 \mathrm{~min}$.

(2) Loading and deflection. Wall 70, subjected to fire test under load of $125 \mathrm{lb} / \mathrm{in}^{2}$ of gross area, failed because of load and deflection at $1 \mathrm{hr} 17$ min, the center lateral deflection before failure being over 3 in. The brick material had a coefficient of expansion within the lower range for

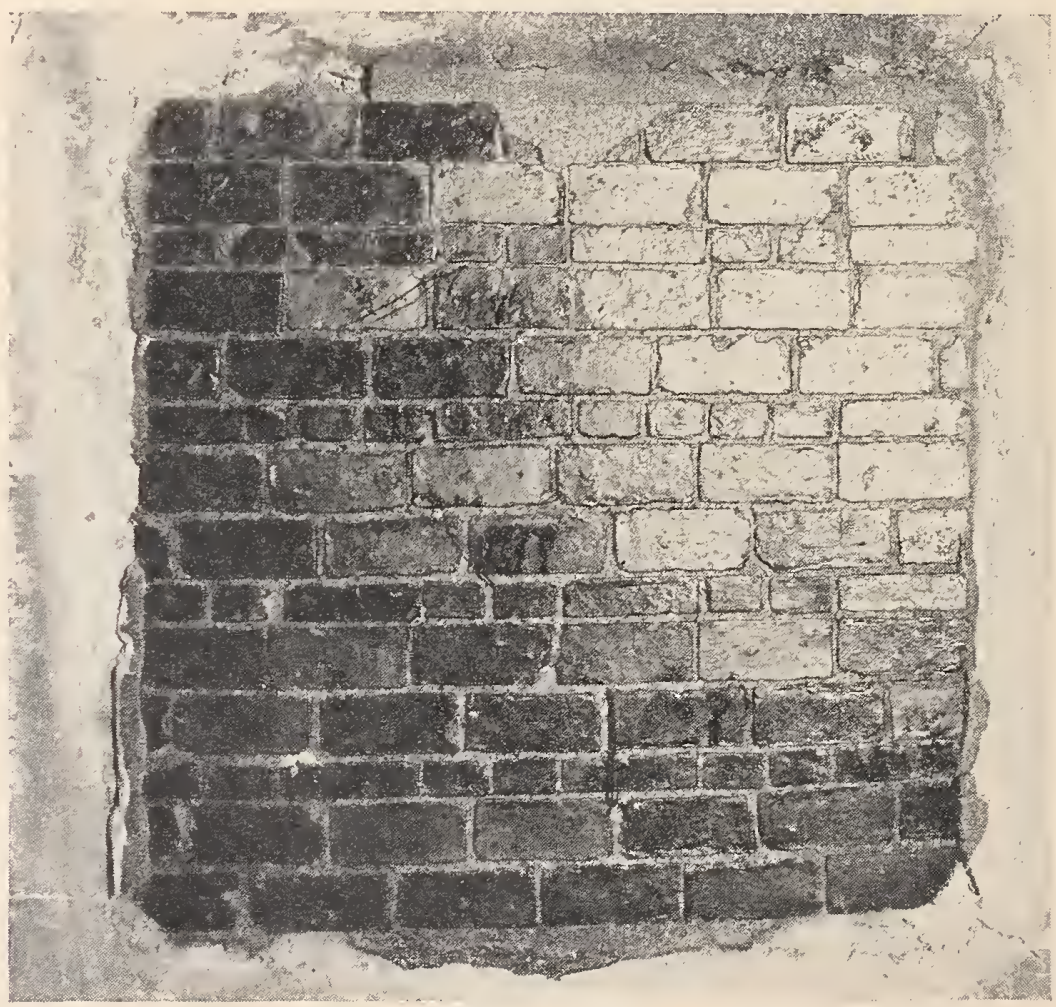

Figure 39. Fire-exposed side of 12-in. flat-bond rolok wall 67 after 10-hr 50-min fire exposure. 


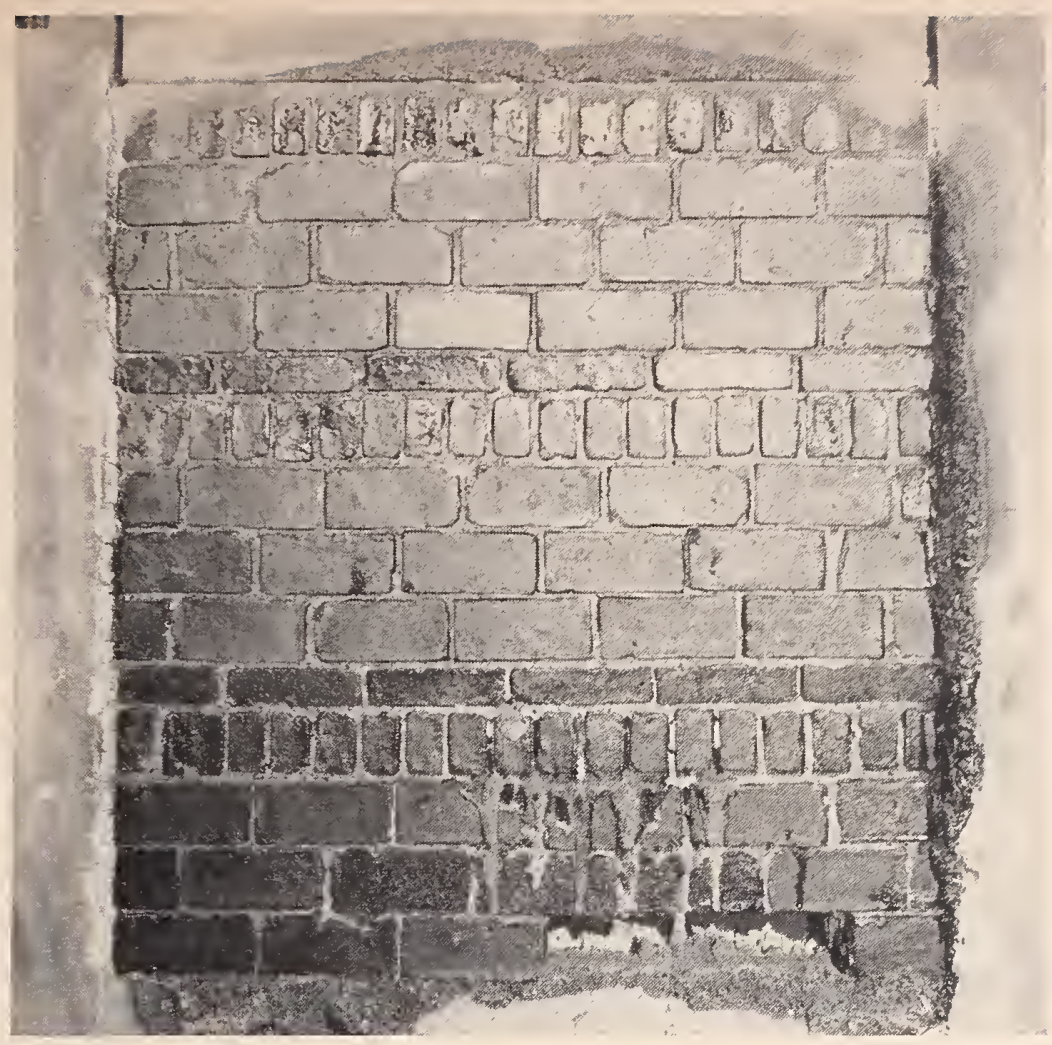

FIgURE 40. Backing side of 12-in. rolok-bak wall 68 after 12-hr 20-min fire test.

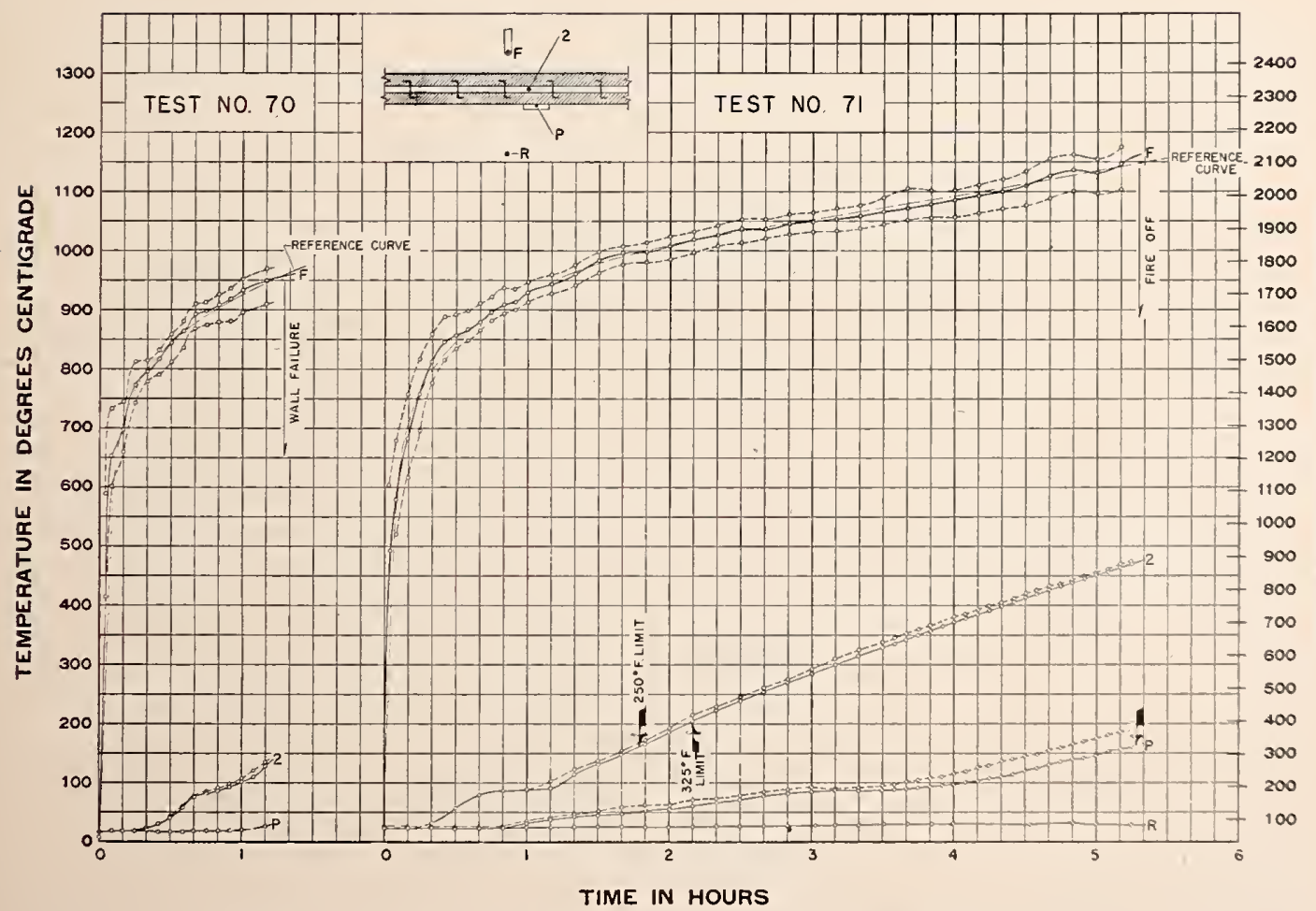

FIGURE 41. Temperatures in fire-endurance test of cavity walls $i 0$ and $\% 1$ of clay bricks from source ('l.A. 
burned clay, and the early failure was apparantly attributable to the cavity design.

Wall 71 was loaded to an average of $80 \mathrm{lb} / \mathrm{in} .^{2}$ on the wythe exposed to fire and $28 \mathrm{lb} / \mathrm{in}^{2}{ }^{2}$ on the unexposed wythe, the average load of $54 \mathrm{lb} / \mathrm{in}^{2}$ being applied $1 \frac{1 / 2}{2}$ in. off-center toward the fireexposed side. This is representative of the load on an exterior 10-in. cavity wall from the live and dead load of floor, roof, and wall constructions. The wall carried the load thus applied during a fire test of $5 \mathrm{hr} 18 \mathrm{~min}$, although it deflected toward the fire a maximum of $3.3 \mathrm{in}$. (fig. 26).

(3) Cracks and open joints. One horizontal crack on the unexposed side of wall 72 opened to $1 / 4$ in., otherwise none with an opening over $1 / 16$ in. was noted. The workmanship in building the walls was good, with joints well filled and pointed.

\subsection{Temperature Rise After Test}

For the tests in which the data were obtained, table 11 gives the average surface-temperature rise at the end of the test when the fire was shut off and the subsequent highest rise of average surface temperature.

It is seen that with the test continued to the fire-endurance limit of the wall, as indicated by an average temperature rise under the asbestos pads near $250 \mathrm{deg} \mathrm{F}$, the subsequent rise for 4 -in. wall 3 increased it to $498 \mathrm{deg} \mathrm{F}$ and for the 8 -in. walls it was increased to the range 374 to $414 \mathrm{deg} \mathrm{F}$.

For 4 -in. wall 4 , the fire exposure ended at 45 $\mathrm{min}$, and the subsequent rise was to $334 \mathrm{deg} \mathrm{F}$. For 8 -in. walls 24 and 34 , the test was stopped about $1 \mathrm{hr}$ short of their fire-endurance limits, and the subsequent rise under the asbestos pads was to 348 and $304 \mathrm{deg} \mathrm{F}$, respectively.

For 12 -in. walls $40,45,49$, and 50 , the tests were continued to their fire-endurance limits as in- dicated by an average temperature rise under the asbestos pads near $250 \mathrm{deg} F$, and the subsequent rise increased it to the range 365 to $399 \mathrm{deg} \mathbf{F}$. In the test of 12 -in. clay-brick wall 41 , stopped at $8 \mathrm{hr}$, the temperature rise to the end of the fire exposure and subsequently was minor. Continued closer to the fire-endurance limit (tests 39,48 , and 66 ), the maximum rise ranged from 282 to $373 \mathrm{deg} \mathrm{F}$.

In all of these tests, the walls remained in front of the furnace with the fuel supply shut off but with the fan supplying air for combustion kept on. Although the furnace temperature fell rapidly, for considerable periods it was at levels substantially above the temperature on the unexposed surface. The temperature rise on the latter was also due to higher temperatures on planes within the wall, which, as the cooling progressed, might also be higher than those on the side that had been exposed to fire.

\subsection{Ignition of Cotton and Excelsior Pads}

In most of the fire tests of large walls, boxes 3 by $3 \mathrm{ft}$ by $3 \frac{1}{2} \mathrm{in}$. deep, filled either with cotton or wood excelsior, were placed against the lower portion of the unexposed surface. The box containing cotton was open on one side, with the cotton in direct contact with the wall. The excelsior box was closed with its side of $3 / 4$-in. pine or $1 / 2$-in. cypress boards in contact with the wall. A thermocouple was placed between the wall and the center of the pad.

Table 12 gives the record of evidence of ignition or nonignition and the corresponding temperatures under the pads. In tests for self-ignition of cotton and wood, some smoke is given off before there is ignition as evidenced by flame or glow. In some of these tests, however, the observation indicating

TABLE 11. Surface-temperature rise after fire test

\begin{tabular}{|c|c|c|c|c|c|c|c|c|c|c|c|c|c|}
\hline \multirow{3}{*}{$\begin{array}{c}\text { Wall or } \\
\text { test }\end{array}$} & \multirow{3}{*}{ Wall design } & \multirow{3}{*}{ Brick material } & \multirow{3}{*}{$\begin{array}{l}\text { Nominal } \\
\text { thickness }\end{array}$} & \multirow{3}{*}{\multicolumn{2}{|c|}{$\begin{array}{l}\text { Duration } \\
\text { of fire } \\
\text { exposure }\end{array}$}} & \multicolumn{2}{|c|}{$\begin{array}{c}\text { Temperature rise at } \\
\text { end of test }\end{array}$} & \multicolumn{6}{|c|}{ Final average temperature rise } \\
\hline & & & & & & \multirow{2}{*}{$\begin{array}{l}\text { Under as- } \\
\text { bestos pad }\end{array}$} & \multirow{2}{*}{$\begin{array}{l}\text { On free } \\
\text { surface }\end{array}$} & \multicolumn{3}{|c|}{ Under asbestos pad } & \multicolumn{3}{|c|}{ On free surface } \\
\hline & & & & & & & & \multicolumn{2}{|c|}{ Time } & Rise & \multicolumn{2}{|c|}{ Time } & Rise \\
\hline $\begin{array}{r}3 \\
4 \\
12 \\
113 \\
13 \\
24\end{array}$ & \begin{tabular}{|} 
Solid \\
$\ldots$ do
\end{tabular} & $\begin{array}{l}\text { Clay } \\
\text { do }\end{array}$ & $\begin{array}{r}\text { in. } \\
4 \\
4 \\
8 \\
8 \\
8\end{array}$ & $\begin{array}{r}h r \\
1 \\
0 \\
5 \\
4 \\
4\end{array}$ & $\begin{array}{l}\min \\
10 \\
45 \\
10 \\
9 \\
0\end{array}$ & $\begin{array}{r}\circ F \\
260 \\
113 \\
247 \\
250 \\
132\end{array}$ & $\begin{array}{l}\circ F \\
212 \\
117 \\
169 \\
176 \\
121\end{array}$ & $\begin{array}{r}h r \\
2 \\
2 \\
7 \\
6 \\
7\end{array}$ & $\begin{array}{c}\min \\
5 \\
0 \\
43 \\
35 \\
20\end{array}$ & $\begin{array}{l}\circ F \\
498 \\
334 \\
414 \\
411 \\
348\end{array}$ & $\begin{array}{r}h r \\
2 \\
1 \\
7 \\
6 \\
6\end{array}$ & $\begin{array}{c}\min \\
2 \\
50 \\
10 \\
10 \\
47\end{array}$ & $\begin{array}{l}\circ F . \\
336 \\
225 \\
270 \\
278 \\
240\end{array}$ \\
\hline $\begin{array}{r}27 \\
128 \\
34 \\
135 \\
136\end{array}$ & $\begin{array}{l}\ldots \text { do } \\
\ldots \ldots \text { do } \\
\ldots \ldots \text { do } \ldots \\
\ldots \ldots \text { do } \\
\ldots \ldots\end{array}$ & $\begin{array}{l}\text { Concrete } \\
\text { Sand-lime }\end{array}$ & $\begin{array}{l}8 \\
8 \\
8 \\
8 \\
8\end{array}$ & $\begin{array}{l}7 \\
6 \\
8 \\
7 \\
6\end{array}$ & $\begin{array}{r}0 \\
17 \\
0 \\
45 \\
41\end{array}$ & $\begin{array}{l}253 \\
253 \\
155 \\
253 \\
253\end{array}$ & $\begin{array}{l}215 \\
197 \\
123 \\
166 \\
172\end{array}$ & $\begin{array}{l}10 \\
10 \\
12 \\
11 \\
10\end{array}$ & $\begin{array}{r}12 \\
5 \\
13 \\
27 \\
20\end{array}$ & $\begin{array}{l}410 \\
377 \\
304 \\
377 \\
374\end{array}$ & $\begin{array}{r}9 \\
8 \\
11 \\
10 \\
9\end{array}$ & $\begin{array}{l}30 \\
45 \\
50 \\
55 \\
45\end{array}$ & $\begin{array}{l}290 \\
284 \\
202 \\
254 \\
246\end{array}$ \\
\hline $\begin{array}{r}39 \\
140 \\
41 \\
45 \\
48\end{array}$ & $\begin{array}{l}\ldots \text { do } \\
\ldots \ldots \text { do } \\
\ldots \\
\ldots \\
\ldots\end{array}$ & $\begin{array}{l}\text { Clay } \\
\text { Shale } \\
\text { Concrete. }\end{array}$ & $\begin{array}{l}12 \\
12 \\
12 \\
12 \\
12\end{array}$ & $\begin{array}{r}11 \\
10 \\
8 \\
12 \\
12\end{array}$ & $\begin{array}{r}36 \\
22 \\
0 \\
50 \\
30\end{array}$ & $\begin{array}{l}159 \\
255 \\
\overline{251} \\
130\end{array}$ & $\begin{array}{r}119 \\
170 \\
98 \\
167 \\
110\end{array}$ & $\begin{array}{l}16 \\
14 \\
17 \\
17\end{array}$ & $\begin{array}{l}25 \\
55 \\
29 \\
53\end{array}$ & $\begin{array}{l}373 \\
365 \\
--\overline{9} \\
282\end{array}$ & $\begin{array}{l}15 \\
14 \\
11 \\
16 \\
17\end{array}$ & $\begin{array}{l}42 \\
12 \\
30 \\
55 \\
37\end{array}$ & $\begin{array}{l}227 \\
232 \\
108 \\
245 \\
192\end{array}$ \\
\hline $\begin{array}{l}149 \\
150 \\
266\end{array}$ & Rolok & Clay do ............ & $\begin{array}{l}12 \\
12 \\
12\end{array}$ & $\begin{array}{r}13 \\
14 \\
8\end{array}$ & $\begin{array}{r}55 \\
0 \\
0\end{array}$ & $\begin{array}{l}255 \\
253 \\
166\end{array}$ & $\begin{array}{l}177 \\
181 \\
130\end{array}$ & $\begin{array}{l}18 \\
17 \\
11\end{array}$ & $\begin{array}{l}20 \\
52 \\
48\end{array}$ & $\begin{array}{l}367 \\
374 \\
341\end{array}$ & $\begin{array}{l}17 \\
17 \\
11\end{array}$ & $\begin{array}{l}26 \\
15 \\
55\end{array}$ & $\begin{array}{l}246 \\
250 \\
204\end{array}$ \\
\hline
\end{tabular}

1 Dried to constant weight at temperatures of $160^{\circ}$ to $180^{\circ} \mathrm{F}$. 2 Plastered on both sides. 
TABLE 12. Temperatures and notes on ignition of large pads

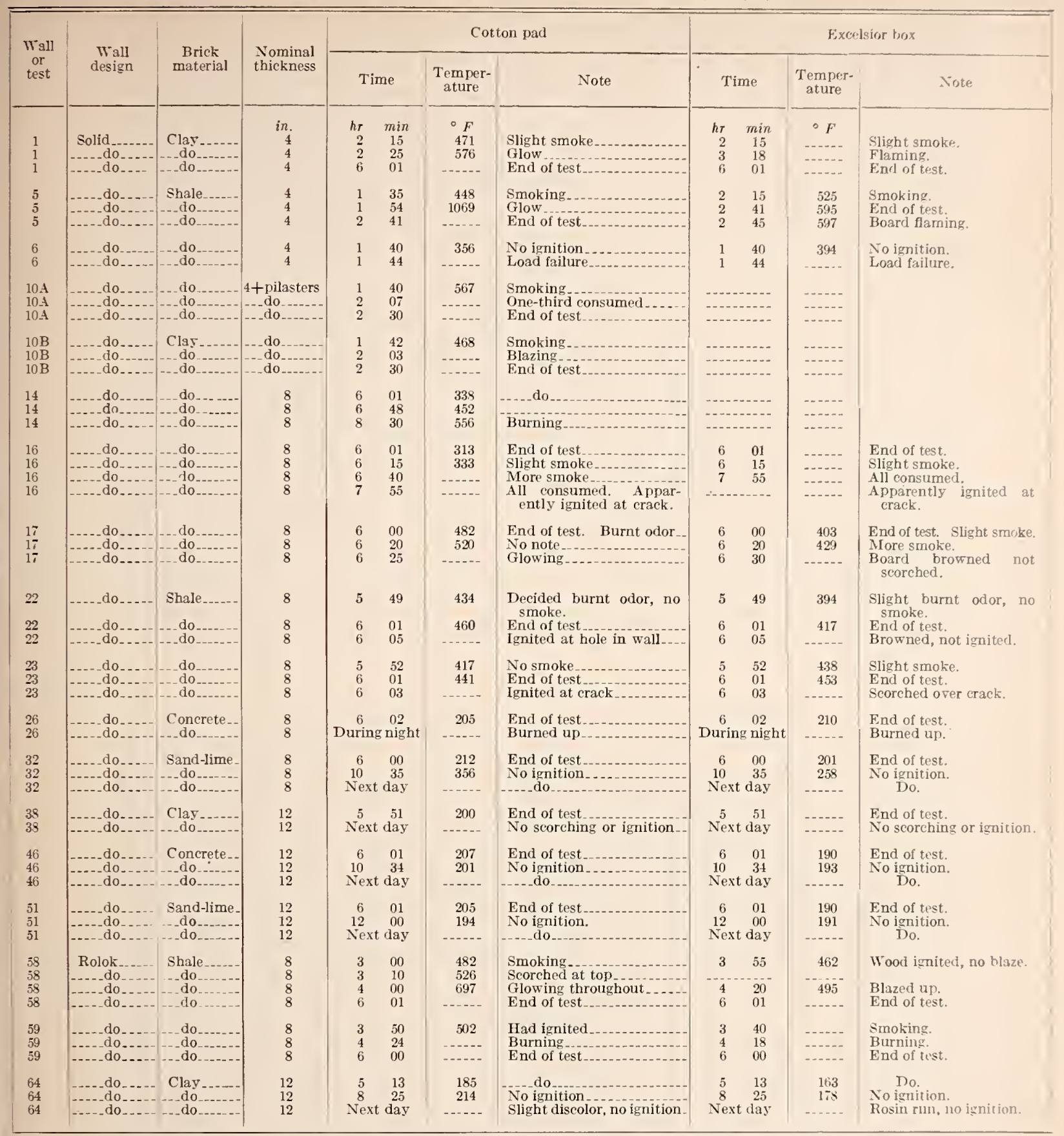


smoke was apparently made at or beyond the time ignition took place. In other cases ignition took place at cracks or open joints and with the thermocouple not in the immediate location it indicated relatively low temperature.

With the time of heating here concerned, which was in the range $1 \frac{1}{2}$ to $12 \mathrm{hr}$, there was no evidence of ignition of the wood or cottion at temperatures below $400^{\circ} \mathrm{F}$. At temperatures in the range $400^{\circ}$ to $450^{\circ}$, smoking sufficient to indicate ignition or approach to ignition was recorded. In the range $450^{\circ}$ to $500^{\circ} \mathrm{F}$, more conclusive evidence of ignition was apparent. The above should be taken as limited to the conditions that prevailed in these tests.

\section{Results of Fire and Hose-Stream Tests}

The results of the fire and hose-stream tests are given in table 13, with a fuller description of the walls tested in table 7 . All of them, except 4 -in. wall 7 and cavity walls 71 and 72 , were built in three or more sections bonded together and of bricks representative of those in the walls subjected to the fire-endurance tests.

The points of interest in these results pertain to the performance of the wall in the fire test preceding the hose-stream application and the stability and structural integrity maintained during the hose-stream application.

At the time most of the fire and hose-stream tests were conducted, the specifications for fire test of load-bearing walls had not been developed and the procedure used in the hose-stream tests followed that for nonbearing walls and partitions. As this did not require the walls to carry load during the hose-stream application, an evaluation is liere made from this standpoint for the constructions that were tested.

\subsection{Performance Under Fire Exposure}

The fire exposure of $1 \mathrm{hr}$ or less duration preceding the hose-stream application did not approach the fire-resistance of any of the walls thus tested. Wall 7 of 4 -in. thickness (fig. 10) and cavity walls 71 and 72 were subjected to the hose stream after the full fire-endurance test, in accordance with the optional procedure.

\subsection{Stability and Integrity}

None of the ralls collapsed in the fire and hosestream tests. For tlose tested unrestrained, there was dislodgment of some bricks near the borders in the wythe on which the stream was applied, but no holes through the wall were formed (figs. 42 and 43). For tests in the restrained condition, all bricks remained in place (figs. 44 and 45 ). The same applies for 10 -in. cavity walls 71 and 72 , the one being tested under load and the other restrained.

All walls were laid up in $1: 1 / 4: 6$ or $1: 1: 6$ cementlime mortar except one-half of wall 77 , which was laid up in $1: 1 \frac{1}{5}: 6$ cement mortar.

TABLE 13. Results of fire and hose-stream tests of brick walls

\begin{tabular}{|c|c|c|c|c|c|c|c|c|c|c|c|c|}
\hline \multirow{2}{*}{$\begin{array}{l}\text { Wall or } \\
\text { test }\end{array}$} & \multirow{2}{*}{$\begin{array}{l}\text { Nominal } \\
\text { thickness }\end{array}$} & \multirow{2}{*}{$\begin{array}{l}\text { Wall } \\
\text { area }\end{array}$} & \multicolumn{2}{|c|}{ Wall design } & \multirow{2}{*}{$\begin{array}{l}\text { Brick symbol for } \\
\text { respective sections }\end{array}$} & \multirow{2}{*}{$\begin{array}{l}\text { Restraint or } \\
\text { loading during } \\
\text { test }\end{array}$} & \multirow{2}{*}{\multicolumn{2}{|c|}{$\begin{array}{l}\text { Duration } \\
\text { of fire } \\
\text { exposure }\end{array}$}} & \multicolumn{3}{|c|}{ Hose-stream application } & \multirow{2}{*}{ Results } \\
\hline & & & Type & $\begin{array}{c}\text { Figure } \\
\text { No. }\end{array}$ & & & & & \multicolumn{2}{|c|}{ Duration } & $\begin{array}{l}\text { Pressure } \\
\text { at nozzle }\end{array}$ & \\
\hline I 7 & in. & $\begin{array}{l}f t^{2} \\
160\end{array}$ & -..._do & $1-\mathbf{A}_{-}$ & CLM, CLI, SHW, & Restrained. & $\begin{array}{c}h r \\
1\end{array}$ & $\min _{25}$ & $\min _{2}$ & $\begin{array}{c}\mathrm{sec} \\
24\end{array}$ & $\begin{array}{ll}l b / i n .^{2} \\
30\end{array}$ & $\begin{array}{l}\text { No wall temp. } \\
\text { above permis- } \\
\text { sible limits or } \\
\text { passege of hose } \\
\text { stream. } \\
\text { Do. }\end{array}$ \\
\hline $\begin{array}{l}74 \\
75\end{array}$ & $\begin{array}{l}8 \\
8\end{array}$ & $\begin{array}{l}171 \\
176\end{array}$ & d..... do & $\begin{array}{l}1-\mathrm{B} \\
1-\mathrm{B}\end{array}$ & CLM, CLI, SH WY, & $\begin{array}{l}\text { Unrestrained } \\
\text { Restrained..-- }\end{array}$ & $\begin{array}{l}0 \\
1\end{array}$ & $\begin{array}{r}59 \\
0\end{array}$ & $\begin{array}{l}5 \\
5\end{array}$ & $\begin{array}{l}0 \\
0\end{array}$ & $\begin{array}{l}50 \\
49\end{array}$ & $\begin{array}{l}\text { Do. } \\
\text { Do. }\end{array}$ \\
\hline 76 & 8 & 176 & All-rolok & $1-D_{-}$ & CLM, CLI, SHW, & . do & 1 & 0 & 5 & 0 & 50 & Do. \\
\hline 77 & 8 & 171 & _do & $1-\mathrm{D}$. & do do & Unrestrained.- & 1 & 0 & 5 & 0 & 41 to 46 & Do. \\
\hline $78 \mathrm{~A}$ & 12 & 173 & Solid - & $1-C_{-}$ & CON, SLP, SLD & Restrained & 1 & 0 & 5 & 0 & 38 to 45 & Do. \\
\hline $278 \mathrm{~B}$ & 12 & 173 & do do..... & $1-\mathrm{C}_{-}$ & do $o_{2}$ & Unrestrained & 1 & 0 & 5 & 0 & 50 to 52 & Do. \\
\hline 71 & 10 & 163 & Cavity & $1-\mathrm{L}-$ & $\mathrm{CLN}$ & $54 \mathrm{lb} / \mathrm{in} .^{2}-\ldots$ & 5 & 18 & 8 & 0 & $45 \ldots \ldots$ & Do. \\
\hline${ }^{1} 72$ & 10 & 160 & 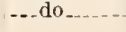 & $1-L_{--}$ & -.... do & Restrained.... & 5 & 3 & $i$ & 57 & 45 & Do. \\
\hline
\end{tabular}

1 Hose stream applied at the end of the fire-endurance test.

2 Test $78 \mathrm{~B}$ was made with the same wall as test $78 \mathrm{~A}$ with top brick course removed so wall could be tested in unrestrained condition. 


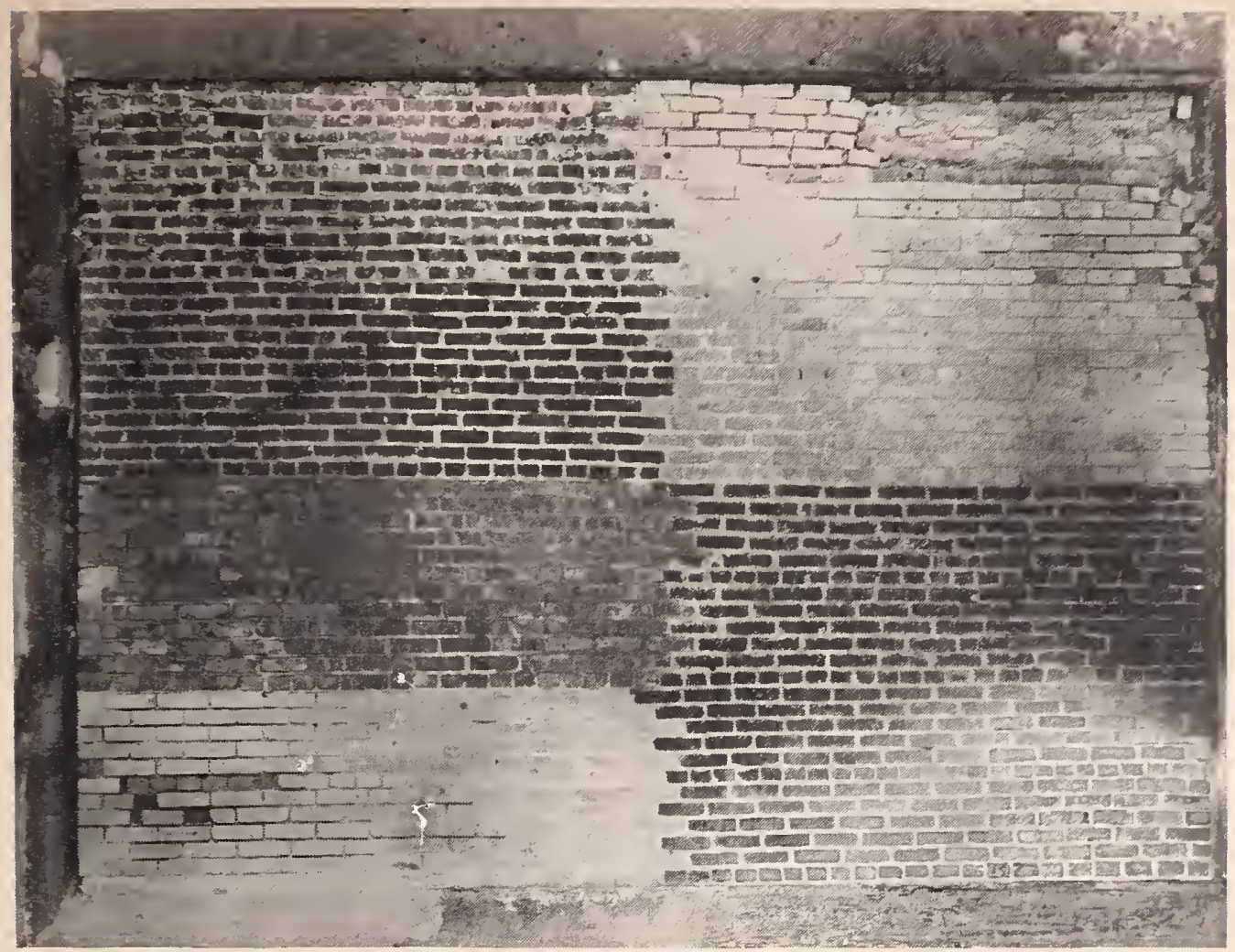

FIGURE 42. Exposed side of 8-in. solid unrestrained wall 74 after fire and hose-stream test.

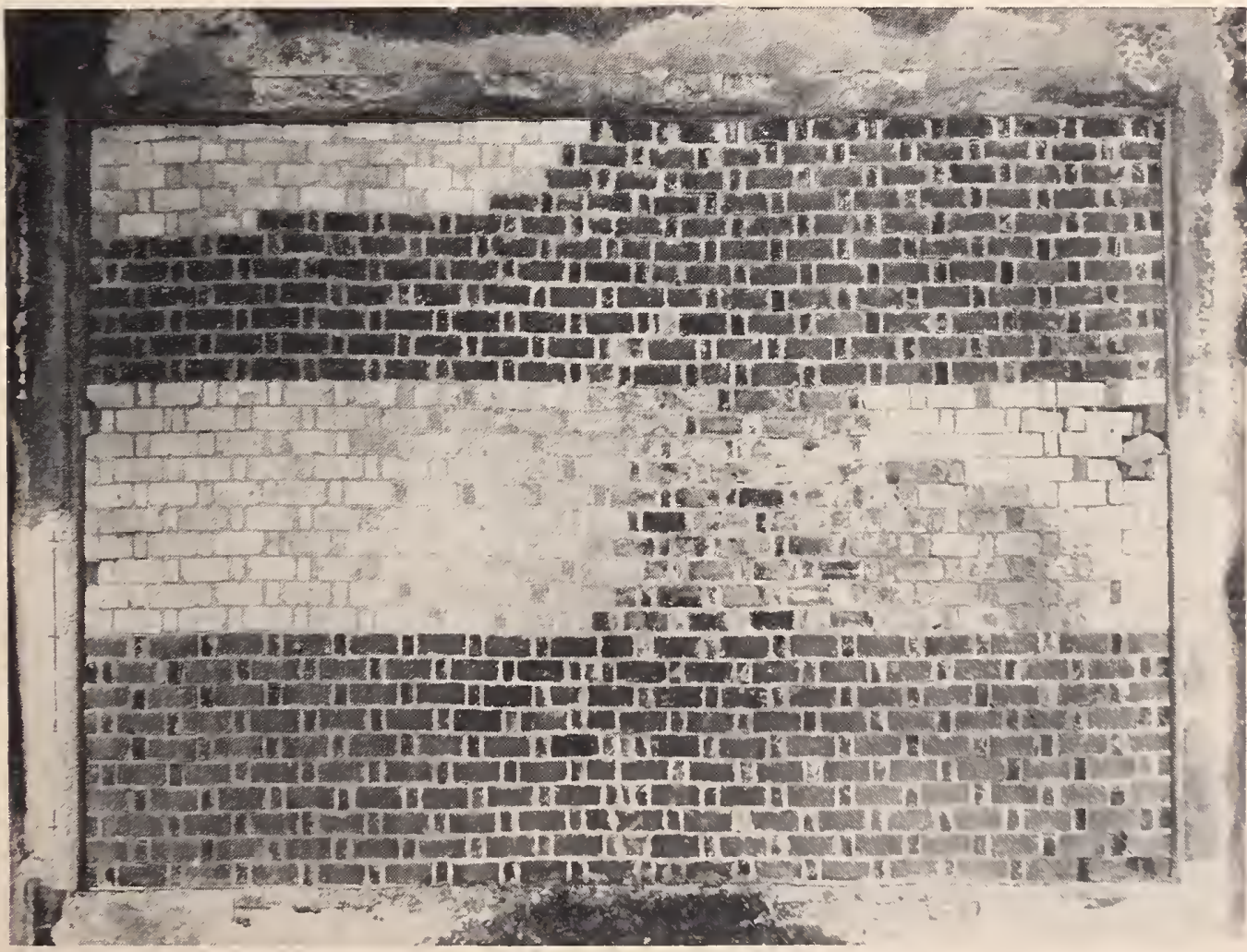

FIGURE 43. Exposed side of 8-in. all-rolok unrestrained wall ir after fire and hose-strezm test. 


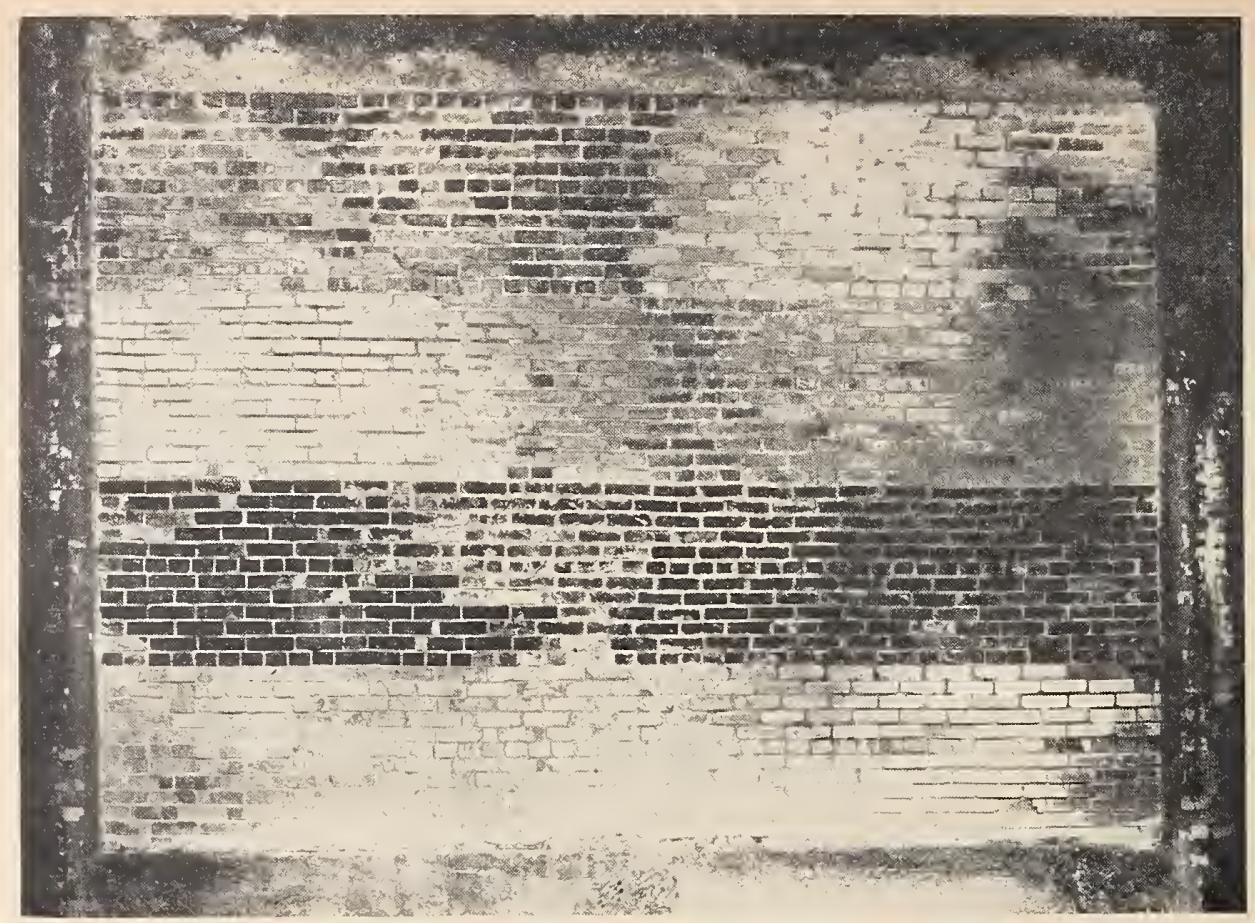

FIGURE 44. Exposed side of 8-in. solid restrained wall 75 after fire and hose-stream test.

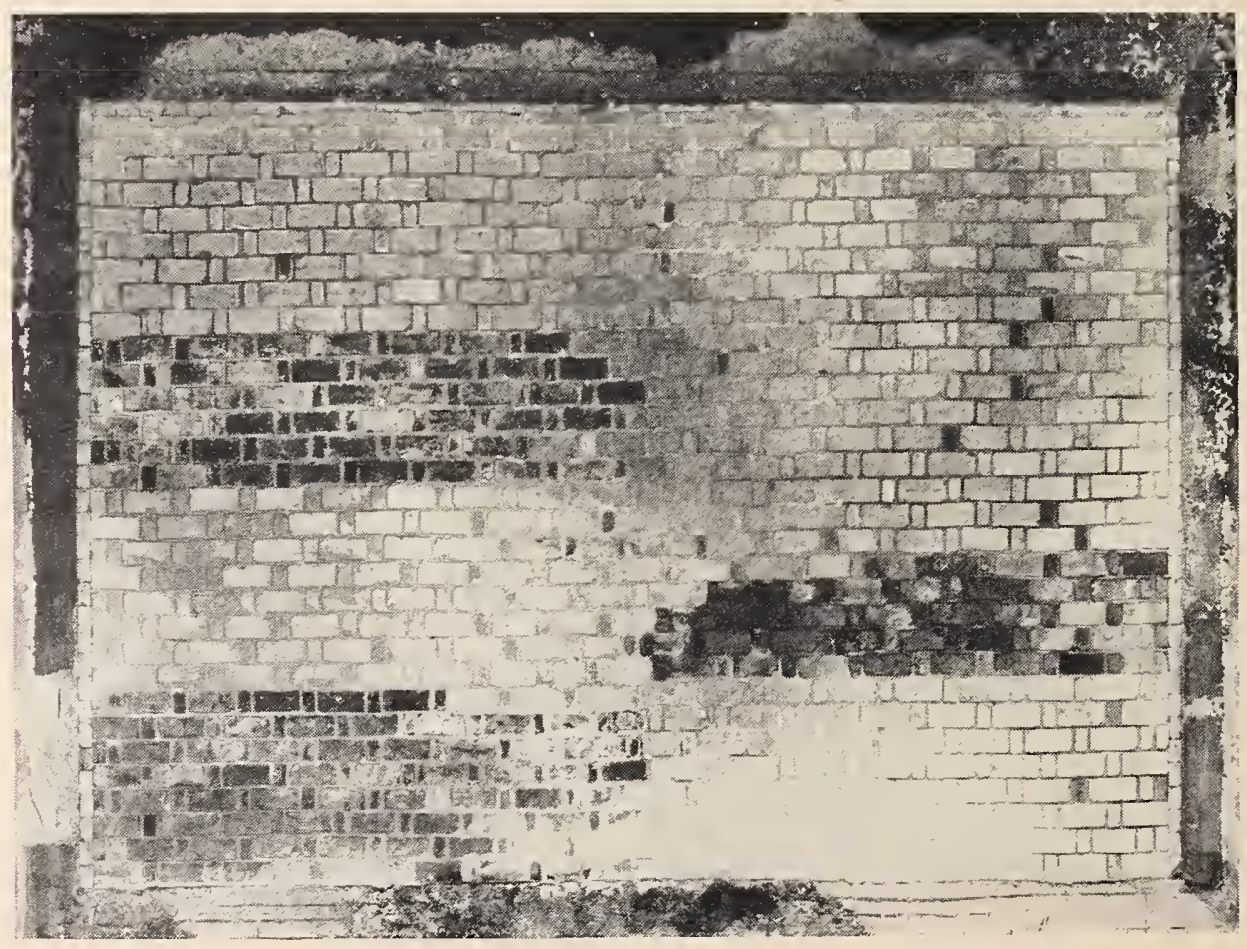

FIGURE 45. Exposed side of 8-in. all-rolok restrained wall 76 after fire and hose-stream test. 


\subsection{Load-Carrying Ability}

a. Walls of 4-in. Thickness

Brick walls of 4 -in. thickness are not generally used for bearing purposes, and in the present tests 4 -in. walls 7 and 73 were not loaded in the fire and hose-stream test.

Clar-brick wall 2 and shale-brick wall 6 of this thickness were each subjected to a load of 80 $\mathrm{lb} /$ in. $^{2}$ in fire-endurance tests that were sustained up to or beyond their fire-endurance limits as determined by temperature rise on the unexposed side. At the end of the fire-endurance test, the load on wall 2 was increased to $160 \mathrm{lb} / \mathrm{in}^{2}$, which was sustained, the center lateral deflection being 2 in.

According to the specifications for conduct of fire tests [6], the fire exposure preceding the hosestream application need not exceed more than one-half the fire-endurance limit, or for 4-in. walls, 30 to $45 \mathrm{~min}$. At this time, the deflection of 4-in. loaded walls was indicated at 2 in. or less (fig. 9), which would be considerably reduced by the hosestream application. Hence, it appears fairly assured that the 4-in. brick walls in this series would hare sustained a load of $80 \mathrm{lb} / \mathrm{in}^{2}{ }^{2}$ during the hose-stream test and subsequent load of 160 $\mathrm{lb} /$ in. $^{2}$. The original strength of the masonry as tested in piers ranged from 1,170 to $1,876 \mathrm{lb} / \mathrm{in}^{2}{ }^{2}$ (table 5).

\section{b. Solid and All-Rolok Walls of 8-in. Thickness}

Talls 74 to 77 were subjected to the hose-stream test in the restrained or unrestrained condition with maximum lateral center deflection for the restrained walls of 1 to $1 \frac{1}{4} \mathrm{in}$. at the end of the l-hr fire test, and 0 to $0.40 \mathrm{in}$. on cooling after the hose-stream application.

The original strength of the masonry for the solid walls as tested in piers ranged from 510 to $1,530 \mathrm{lb} /$ in. $^{2}$ of gross area, and of piers taken from the walls after fire and hose-stream tests, from 390 to $540 \mathrm{lb} /$ in. $^{2}$ For the all-rolok walls, the original strength of the masonry in piers had a range from 440 to $1,470 \mathrm{lb} / \mathrm{in}^{2}$ (table 5 ).

Considering the above and the low deflections at the end of the 1-hr fire exposure and on cooling after the hose-stream application, it appears that the walls would have carried the $160-\mathrm{lb} /$ in. $^{2}$ loarl during the fire and hose-stream test and twice the load, or $320 \mathrm{lb} / \mathrm{in}^{2}$, on cooling after the test. It might be noted that 8 -in. walls carried working loads in fire-endurance tests for 6 to $8 \mathrm{hr}$ (tables 9 and 10).

\section{c. Solid and All-Rolok Walls of 12-in. Thickness}

Two fire and hose-stream tests were made with 12 -in. solid wall 78 , one with the wall restrained, the other unrestrained. The maximum deflection at the end of the 1-hr fire exposure was $0.80 \mathrm{in}$. and after the water application, 0.35 in. The original strength of the masonry in piers ranged from 480 to $1,040 \mathrm{lb} / \mathrm{in}^{2}$ In one comparison with piers of concrete bricks, the original strength was $850 \mathrm{lb} / \mathrm{in}^{2}$ and for the pier taken from the wall after hose-stream tests $78 \mathrm{~A}$ and $78 \mathrm{~B}, 580 \mathrm{lb} / \mathrm{in.}^{2}$ (table 5).

As for the 8-in. walls, the low lateral reflertions during test and the strength of the masonry indicate adequate ability to carry the loads required by the present testing procedure.

No fire and hose-stream tests were made with 12-in. all-rolok hollow walls because the required resistance for the purpose was considerel as shown by the tests of 8 -in. walls of the same design.

\section{d. Cavity Walls}

Cavity wall 71 was subjecterl to the fire and hose-stream test under the loarl carrierl in the preceding fire-endurance test and wall 72 in the restrained condition following the $5 \mathrm{hr} 3 \mathrm{~min}$ fire-endurance test.

The load carried during test was reapplied on wall 71 after cooling following the hose-stream application, but on further increase, it failer at a load 50 percent in excess of the loar carrierl during the fire test. Although this is short of the $100-$ percent excess load to be carried, it is noted that the wall had been exposed to fire for $5 \mathrm{hr} 18 \mathrm{~min}$ in the preceding fire-endurance test as compared with the 1 -hr fire exposure required by the regular fire and hose-stream test procedure.

\subsection{Other Wall Designs}

Nio fire and hose-stream tests were conducted with various rolok and rolok-bak designs, the fire-endurance tests of which were only with walls of the smaller size (walls 62, 63, and 65 to 69, tables 7 and 10).

\section{Effect of Fire Tests on Strength of Brick and Masonry}

Although the condition of the construction after the fire test has no bearing on the rating based on performance in the test, it is informative as to the possibility of reuse after fire. Representative samples of bricks were taken from the walls after the fire tests, with which orer 2,000 strength and absorption tests were made. Specimens of masonry were also cut from the walls of approximately the same size as the auxiliary specimens laid up when the walls were built.

Cracking of masonry and bricks from differential expansion and the stresses induced by the fire exposure was an apparent cause of loss of strength. The effect on the brick materials as such varied with type of material and temperature. For clay and shale bricks subjected to temperatures in a limited range above those at which ther were fired in the kiln, there were incliestions of gain in strength where not offset by other efferets of the fire exposure.

The concrete and sand-lime bricks lost strength due to dehydration of the bonding constituents. When subjected in the fire tests to tempelatures not greatly exceding $212^{\circ} \mathrm{F}$, there was an incerase in strength in some cases. This may have been due to the resulting temperature and moistmet conclitions. 
8.1. Compressive Strength of Bricks

Table 14 gives the results for half-bricks tested in compression on edge and table 15 the results with tests on side or flatwise. Fairly representative samples were obtained except where the bricks were fused and fluxed.

TABLE 14. Effect of fire tests on compressive strength of bricks tested on edge

\begin{tabular}{|c|c|c|c|c|c|c|}
\hline \multicolumn{2}{|r|}{ Brick } & \multirow[b]{2}{*}{ Type of test } & \multirow[b]{2}{*}{ Location of bricks } & \multirow{2}{*}{$\begin{array}{l}\text { A verage } \\
\text { original } \\
\text { strength }\end{array}$} & \multicolumn{2}{|c|}{ Effect of fire test } \\
\hline Symbol & Material & & & & $\begin{array}{c}\text { Number } \\
\text { of tests }\end{array}$ & $\begin{array}{l}\text { A verage } \\
\text { loss }(-) \\
\text { gain }(+)\end{array}$ \\
\hline $\begin{array}{l}\text { CLM } \\
\text { CLMI } \\
\text { CLM } \\
\text { CLMI } \\
\text { CLM }\end{array}$ & $\begin{array}{l}\text { Clay } \\
-.-.- \\
- \text { do }_{--}\end{array}$ & $\begin{array}{l}\text { Fire endurance } \\
\text { Fire and water- } \\
\text { Fire endurance }-10\end{array}$ & $\begin{array}{l}\text { Fire exposed in 4-, 8-, or } 12 \text {-in. solid walls } \\
\text { Fire exposed in 4-or } 8 \text {-in. solid walls } \\
\text { Middle course in } 12 \text {-in, solid wall } \\
\text { Unexposed in } 8 \text { - or } 12 \text {-in. solid walls. } \\
\text { Unexposed in 8-in. solid walls }\end{array}$ & $\begin{array}{r}\tau b / i n .2 \\
2,530 \\
1,960 \\
2,560 \\
2,400 \\
1,960\end{array}$ & $\begin{array}{r}76 \\
9 \\
7 \\
71 \\
10\end{array}$ & $\begin{array}{r}\text { Percent } \\
-14.8 \\
-13.9 \\
-6.2 \\
-2.9 \\
+11.5\end{array}$ \\
\hline $\begin{array}{l}\text { CLI } \\
\text { CLI } \\
\text { CLI } \\
\text { SHW } \\
\text { SHW }\end{array}$ & 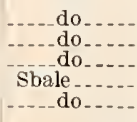 & 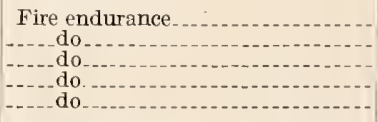 & 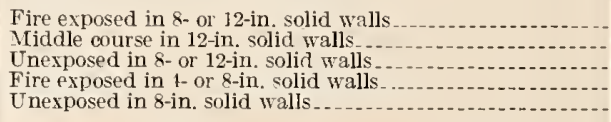 & $\begin{array}{l}2,330 \\
2,330 \\
2,330 \\
6,400 \\
6.400\end{array}$ & $\begin{array}{l}17 \\
13 \\
35 \\
25 \\
24\end{array}$ & $\begin{array}{r}-18.5 \\
-0.6 \\
-4.2 \\
-15.0 \\
-17.0\end{array}$ \\
\hline $\begin{array}{l}\text { SHW } \\
\text { CON } \\
\text { CON } \\
\text { COD } \\
\text { COD }\end{array}$ & 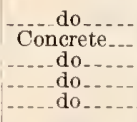 & $\begin{array}{l}\text { Fire and water } \\
\text { Fire endurance } \\
\text { Fire endurance to } 13 \mathrm{hr} 55 \mathrm{~min}\end{array}$ & $\begin{array}{l}\text { Fire exposed in } 8 \text { - or } 12 \text {-in. solid walls } \\
\text { Unexposed in } 8 \text { or } 12 \text {-in, solid walls } \\
\text { Fire exposed in 12-in. solid wall } \\
\text { Middle course in } 12 \text {-in. solid wall }\end{array}$ & $\begin{array}{l}6,400 \\
1,530 \\
1,530 \\
2,290 \\
2,290\end{array}$ & $\begin{array}{r}9 \\
33 \\
23 \\
(1) \\
14\end{array}$ & $\begin{array}{l}-11.2 \\
-21.8 \\
+7.0 \\
-46.3\end{array}$ \\
\hline $\begin{array}{l}\text { COD } \\
\text { SLP } \\
\text { SLP } \\
\text { SLP } \\
\text { SLP }\end{array}$ & 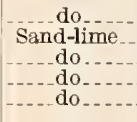 & $\begin{array}{l}\text { Fire endurance... } \\
\text { Fire and water... } \\
\text { Fire endurance... } \\
\text { Fire and water }\end{array}$ & $\begin{array}{l}\text { Unexposed in 12-in. solid wall } \\
\text { Fire exposed in } 8-\text { or } 12 \text {-in. solid walls } \\
\text { Fire exposed in } 4-, \text { - } 8 \text {, or } 12 \text {-in. solid walls } \\
\text { Middle course in 12-in. solid wall }\end{array}$ & $\begin{array}{l}2.290 \\
4,720 \\
4,720 \\
4,720 \\
4,720\end{array}$ & $\begin{array}{l}20 \\
31 \\
10 \\
22 \\
16\end{array}$ & $\begin{array}{l}+16.4 \\
-50.9 \\
-43.0 \\
-13.9 \\
-21.8\end{array}$ \\
\hline $\begin{array}{l}\text { SLP } \\
\text { SLP } \\
\text { SLD } \\
\text { SLD } \\
\text { SLD }\end{array}$ & 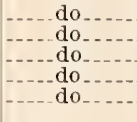 & $\begin{array}{l}\text { Fire endurance } \\
\text { Fire and water.......... } \\
\text { Fire endurance. }\end{array}$ & $\begin{array}{l}\text { Unexposed in 8- or 12-in. solid walls } \\
\text { do } \\
\text { Unexposed in 8-in. solid walls }\end{array}$ & $\begin{array}{l}4,720 \\
4,720 \\
2.270 \\
2,260 \\
1,690\end{array}$ & $\begin{array}{l}50 \\
21 \\
40 \\
48 \\
15\end{array}$ & $\begin{array}{r}-23.9 \\
-17.1 \\
-45.0 \\
+0.1 \\
+6.3\end{array}$ \\
\hline $\begin{array}{l}\text { CLM } \\
\text { CLM } \\
\text { CLM } \\
\text { CLI } \\
\text { CLI }\end{array}$ & 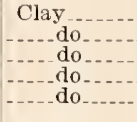 & $\begin{array}{l}\text { Fire endurance.-. } \\
- \text { do }_{-} \text {do }\end{array}$ & $\begin{array}{l}\text { Fire exposed in 8- or } 12 \text {-in rolok walls } \\
\text { Middle course in 12-in. rolok wall } \\
\text { Unexposed in 8- or } 12 \text {-in. rolok walls } \\
\text { Fire exposed in 8-in. rolok walls. } \\
\text { Unexposed in 8-in, rolok walls. }\end{array}$ & $\begin{array}{l}2,560 \\
2.560 \\
2,560 \\
2,330 \\
2,330\end{array}$ & $\begin{array}{l}24 \\
17 \\
19 \\
27 \\
25\end{array}$ & $\begin{array}{r}+6.2 \\
+18.8 \\
+1.3 \\
+8.5 \\
+0.9\end{array}$ \\
\hline $\begin{array}{l}\text { SHW } \\
\text { SHW }\end{array}$ & Shale & -do_ & $\begin{array}{l}\text { Fire exposed in 8-in. rolok walls } \\
\text { Unexposed in 8-in. rolok walls................. }\end{array}$ & $\begin{array}{l}5,840 \\
5,910\end{array}$ & $\begin{array}{l}23 \\
31\end{array}$ & $\begin{array}{l}-12.6 \\
-13.0\end{array}$ \\
\hline
\end{tabular}

${ }_{1}$ No tests. $\quad 2$ Fluxed.

TABLE 15. Effect of fire tests on compressive strength of bricks tested on side

\begin{tabular}{|c|c|c|c|c|c|c|}
\hline \multicolumn{2}{|c|}{ Brick } & \multirow[b]{2}{*}{ Type of test } & \multirow[b]{2}{*}{ Location of bricks } & \multirow{2}{*}{$\begin{array}{l}\text { A verage } \\
\text { original } \\
\text { strength }\end{array}$} & \multicolumn{2}{|c|}{ Effect of fire test } \\
\hline Symbol & Material & & & & $\begin{array}{l}\text { Number } \\
\text { of tests }\end{array}$ & $\begin{array}{l}\text { A verage } \\
\text { loss }(-), \\
\text { gain }(+)\end{array}$ \\
\hline $\begin{array}{l}\text { CLMI } \\
\text { CLMI } \\
\text { CLI } \\
\text { CLI } \\
\text { SHW }\end{array}$ & 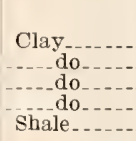 & 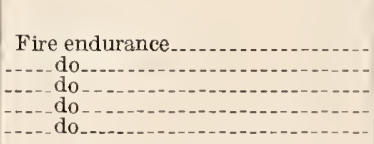 & 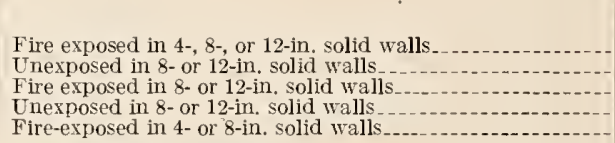 & $\begin{array}{l}\text { lb/in. }{ }^{2} \\
3,140 \\
3,170 \\
2,920 \\
2,920 \\
8,610\end{array}$ & $\begin{array}{r}29 \\
32 \\
12 \\
4 \\
23\end{array}$ & $\begin{array}{l}\text { Percent } \\
-11.7 \\
-10.2 \\
-8.8 \\
-4.3 \\
-14.9\end{array}$ \\
\hline $\begin{array}{l}\text { SHW } \\
\text { CON } \\
\text { CON } \\
\text { COD } \\
\text { COD }\end{array}$ & 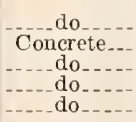 & Fire endurance to 13 br $55 \mathrm{~min}$ & $\begin{array}{l}\text { Unexposed in 8-in. solid walls } \\
\text { Fire exposed in 8- or } 12 \text {-in. solid walls.-. } \\
\text { Unexposed in 8- or } 12 \text {-in. solid walls } \\
\text { Fire exposed in 12-in. solid wall } \\
\text { Middle course in 12-in. solid wall }\end{array}$ & $\begin{array}{l}8,110 \\
2,780 \\
2,780 \\
2,920 \\
2,920\end{array}$ & $\begin{array}{r}11 \\
9 \\
18 \\
(1) \\
10\end{array}$ & $\begin{array}{r}-22.5 \\
-47.5 \\
-19.7 \\
(2) \\
-0.8\end{array}$ \\
\hline $\begin{array}{l}\text { COD } \\
\text { SLP } \\
\text { SLP } \\
\text { SLP } \\
\text { SLP }\end{array}$ & 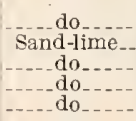 & $\begin{array}{l}\text { Fire endurance } \\
\text { Fire and water } \\
\text { Fire endurance- }\end{array}$ & $\begin{array}{l}\text { Unexposed in 12-in. solid wall } \\
\text { Fire exposed in 8- or 12-in. solid walls.-. } \\
\text { Fire exposed in 4-, 8-, or } 12 \text {-in. solid walls } \\
\text { Middle course in 12-in, solid wall } \\
\text { Unexposed in 8- or } 12 \text {-in. solid walls }\end{array}$ & $\begin{array}{l}2,920 \\
4,630 \\
4,630 \\
4,630 \\
4,630\end{array}$ & $\begin{array}{r}10 \\
13 \\
8 \\
9 \\
25\end{array}$ & $\begin{array}{l}-19.3 \\
-33.6 \\
-14.1 \\
-11.7 \\
+12.9\end{array}$ \\
\hline $\begin{array}{l}\text { SLP } \\
\text { SLD } \\
\text { SLD } \\
\text { CLM } \\
\text { CLM }\end{array}$ & 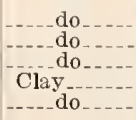 & $\begin{array}{l}\text { Fire and water } \\
\text { Fire endurance } \\
\text { do do }\end{array}$ & $\begin{array}{l}\text { Fire exposed in 8-in. solid walls } \\
\text { Unexposed in } 8 \text {-in. solid walls } \\
\text { Fire exposed in 8-or } 12 \text {-in, rolok walls } \\
\text { Unexposed in 12-in. rolok wall }\end{array}$ & $\begin{array}{l}4,630 \\
2,530 \\
2,580 \\
3,280 \\
3,280\end{array}$ & $\begin{array}{r}8 \\
22 \\
22 \\
6 \\
5\end{array}$ & $\begin{array}{r}-2.4 \\
-27.8 \\
-9.4 \\
+17.7 \\
+2.2\end{array}$ \\
\hline $\begin{array}{l}\text { CLI } \\
\text { SHW } \\
\text { SHW }\end{array}$ & Sbale..- & - & $\begin{array}{l}\text { Fire exposed in 8-in. rolok walls } \\
\text { Unexposed in 8-in. rolok walls }\end{array}$ & $\begin{array}{l}2,920 \\
6,750 \\
6,920\end{array}$ & $\begin{array}{l}11 \\
11 \\
14\end{array}$ & $\begin{array}{r}-13.1 \\
+3.4 \\
-7.4\end{array}$ \\
\hline
\end{tabular}


Although the results indicate a considerable range in loss of strength as between bricks from the different sources, in most cases the effect is not of a degree that would preclude reuse of the bricks or masonry. Howerer, other conditions, such as the effect on the mortar and deflection and cracking of the wall resulting from the fire test, would also have a bearing thereon.

\subsection{Transverse Strength of Bricks}

Table 16 gives the flexure strength of bricks as determined with whole bricks on 7 -in. span. The loss is seen to be much greater than for the compressive strength. As many of the bricks were broken in the wall from the fire tests and were not included in the samples taken, the actual loss was greater than indicated in the table. Dismantling of the walls also indicated that transverse rupture of the bricks, particularly in header courses, was the most serious effect having a bearing on possible reuse of the construr:tion after test.

\subsection{Absorption}

No detailed results of the absorption tests are given here, but in general the fire test reducert the absorption. It did not appear that the change in absorption had a significant bearing on the possibility of reusing the bricks or masonry

\subsection{Masonry Strength}

In seven comparisons obtained from table 5 on loss of strength of 8 - and 12-in. solid masonry in the fire-endurance test, the average is 40 percent. For six similar comparisons obtained with walls in the fire and hose-stream tests, the average loss was 40.5 percent.

TABLE 16. Effect of fire tests on the flexure strength of bricks

\begin{tabular}{|c|c|c|c|c|c|c|}
\hline \multicolumn{2}{|c|}{ Briek } & \multirow[b]{2}{*}{ Type of test } & \multirow[b]{2}{*}{ Location of bricks } & \multirow{2}{*}{$\begin{array}{l}\text { A verage } \\
\text { original } \\
\text { strength }\end{array}$} & \multicolumn{2}{|c|}{ Effeet of fire test } \\
\hline Symbol & Material & & & & $\begin{array}{l}\text { Number } \\
\text { of tests }\end{array}$ & $\begin{array}{l}\text { Arerage } \\
\text { loss }(-) \text {, } \\
\text { gain }(+)\end{array}$ \\
\hline $\begin{array}{l}\text { CLMI } \\
\text { CLMI } \\
\text { CLMI } \\
\text { CLM } \\
\text { CLMI }\end{array}$ & 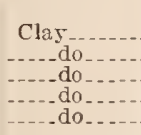 & $\begin{array}{l}\text { Fire endurance.. } \\
\text { Fire and water. } \\
\text { Fire endurance.. }\end{array}$ & $\begin{array}{l}\text { Fire-exposed stretchers in 4-, 8-, 12-in, solid walls } \\
\text { Fire-exposed headers in 8- or 12-in. solid walls } \\
\text { Fire-exposed stretehers in 4- or 8-in. solid walls } \\
\text { Middle course stretchers in 12-in. solid wall } \\
\text { Unexposed stretchers in 8- or 12-in. solid walls }\end{array}$ & $\begin{array}{r}\text { lb/in.2 } .^{2} \\
890 \\
900 \\
1,210 \\
760 \\
950\end{array}$ & $\begin{array}{r}56 \\
45 \\
10 \\
6 \\
34\end{array}$ & $\begin{array}{l}\text { Percent } \\
--3.8 \\
-12.6 \\
-72.9 \\
+4.7 \\
-2.0\end{array}$ \\
\hline $\begin{array}{l}\text { CLI } \\
\text { CLI } \\
\text { CLI } \\
\text { CLI } \\
\text { SHW }\end{array}$ & 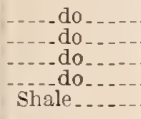 & $\begin{array}{l}\ldots \text { do } \\
\ldots \text { do }\end{array}$ & $\begin{array}{l}\text { Fire-exposed strctchers in 8- or 12-in. solid walls } \\
\text { Fire-exposed headers in } 8 \text { - or } 12 \text {-in. solid walls } \\
\text { Middle course stretchers in } 12 \text {-in. solid wall } \\
\text { Unexposed stretehers in 8- or } 12 \text {-in. solid walls } \\
\text { Fire-exposed stretchers in 4- or 8-in. solid walls. }\end{array}$ & $\begin{array}{l}1,180 \\
1,180 \\
1,180 \\
1,180 \\
2,040\end{array}$ & $\begin{array}{r}24 \\
30 \\
5 \\
11 \\
50\end{array}$ & $\begin{array}{l}-5 \times .4 \\
-56.9 \\
-22.3 \\
-25.2 \\
-84.3\end{array}$ \\
\hline $\begin{array}{l}\text { SHW } \\
\text { SHW } \\
\text { CON } \\
\text { CON } \\
\text { CON }\end{array}$ & 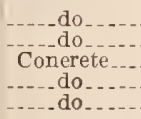 & Fire and water. & $\begin{array}{l}\text { Fire-exposed headers in 8-in. solid walls } \\
\text { Unexposed stretchers in 8-in. solid walls } \\
\text { Fire-exposed stretchers in 8- or } 12 \text {-in. solid walls } \\
\text { Fire-exposed headers in 8- or } 12 \text {-in. solid walls } \\
\text { Fire-exposed stretchers in 4-, 8-, or 12-in. solid walls.... }\end{array}$ & $\begin{array}{r}2,020 \\
2,020 \\
650 \\
650 \\
650\end{array}$ & $\begin{array}{r}10 \\
12 \\
18 \\
22 \\
9\end{array}$ & $\begin{array}{l}-49.2 \\
+27.2 \\
-52.2 \\
-74.0 \\
-75.9\end{array}$ \\
\hline $\begin{array}{l}\operatorname{CON} \\
\operatorname{CON} \\
\operatorname{CON} \\
\operatorname{CON} \\
\operatorname{COD}\end{array}$ & 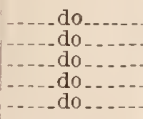 & $\begin{array}{l}\text { Fire endurance } \\
\text { Fire and water } \\
\text { Fire endurance to } 13 \mathrm{hr} 55 \mathrm{~min} . . .\end{array}$ & $\begin{array}{l}\text { Fire-exposed headers in 8- or 12-in. solid walls } \\
\text { Unexposed stretchers in } 8 \text { - or } 12 \text {-in. solid walls. } \\
\text { Unexposed headers in } 12 \text {-in. solid wall } \\
\text { Unexposed stretchers in } 8 \text { - or } 12 \text {-in. solid walls } \\
\text { Fire-exposed headers or stretchers in 12-in. solid wall }\end{array}$ & $\begin{array}{l}650 \\
650 \\
650 \\
650 \\
780\end{array}$ & $\begin{array}{r}5 \\
23 \\
6 \\
5 \\
(1)\end{array}$ & $\begin{array}{l}-41.1 \\
-30.1 \\
-35.2 \\
-10.3 \\
(2)\end{array}$ \\
\hline $\begin{array}{l}\text { COD } \\
\text { COD } \\
\text { COD } \\
\text { SLP } \\
\text { SLP }\end{array}$ & $\begin{array}{l}\text { do } \\
\text { Sand -lime } \\
\end{array}$ & $\begin{array}{l}\text { Fire } \text { endurance } \\
\quad \text { do }\end{array}$ & $\begin{array}{l}\text { Middle course stretchers in 12-in. solid wall } \\
\text { Unexposed headers in 12-in. solid wall } \\
\text { Unexposed stretchers in 12-in. solid wall } \\
\text { Fire-exposed stretehers in } 8 \text { - or } 12 \text {-in, solid walls } \\
\text { Fire-exposed headers in } 8 \text { - or } 12 \text {-in, solid walls.... }\end{array}$ & $\begin{array}{l}780 \\
780 \\
780 \\
930 \\
930\end{array}$ & $\begin{array}{l}10 \\
10 \\
10 \\
17 \\
23\end{array}$ & $\begin{array}{l}-5.2 \\
-13.3 \\
-43.1 \\
-04.5 \\
-1.4\end{array}$ \\
\hline $\begin{array}{l}\text { SLP } \\
\text { SLP } \\
\text { SLP } \\
\text { SLP } \\
\text { SLP }\end{array}$ & 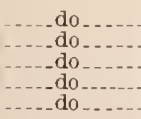 & $\begin{array}{l}\text { Fire and water.... } \\
\text { Fire enduranee } \\
\text { Fire and water. }\end{array}$ & $\begin{array}{l}\text { Fire-exposed stretehers in 4-, 8-, or 12-in. solid walls } \\
\text { Fire-exposed headers in 8- or 12-in. solid walls } \\
\text { Middle course stretchers in 12-in. solid wall } \\
\text { Unexposed stretchers in } 8 \text { - or } 12 \text {-in. solid walls } \\
\text { Middle course stretehers in 12-in, solid wall }\end{array}$ & $\begin{array}{l}930 \\
930 \\
930 \\
930 \\
930\end{array}$ & $\begin{array}{r}s \\
9 \\
30 \\
6\end{array}$ & $\begin{array}{l}-8.7 \\
-74.2 \\
-205 \\
-31.5 \\
-27,0\end{array}$ \\
\hline $\begin{array}{l}\text { SLP } \\
\text { SLP } \\
\text { SLP } \\
\text { SLD } \\
\text { SLD }\end{array}$ & 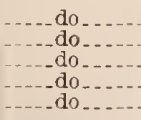 & $\begin{array}{l}\text { Fire endurance... } \\
\text { Fire and water.... } \\
\text { Fire endurance... }\end{array}$ & $\begin{array}{l}\text { Unexposed headers in 12-in. solid wall } \\
\text { Unexposed stretchers in 8-0r 12-in, solid walls } \\
\text { Unexposed headers in 12-in. solid wall } \\
\text { Fire-exposed stretehers in 8-in, solid walls } \\
\text { Fire-exposed headers in 8-in. solid walls }\end{array}$ & $\begin{array}{l}930 \\
930 \\
930 \\
600 \\
660\end{array}$ & $\begin{array}{c}3 \\
11 \\
20 \\
18 \\
18\end{array}$ & $\begin{array}{l}-31.9 \\
-31.9 \\
-32.11 \\
-31.6 \\
-3.1\end{array}$ \\
\hline $\begin{array}{l}\text { SLD } \\
\text { CLMI } \\
\text { CLMI } \\
\text { CLMI } \\
\text { CLMI }\end{array}$ & 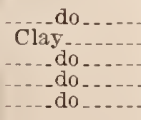 & 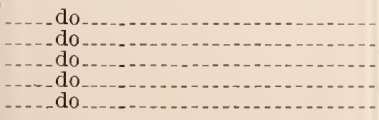 & $\begin{array}{l}\text { Unexposed stretchers in 8-in. solid walls } \\
\text { Fire-exposed stretchers in 8-or 12-in. rolok walls } \\
\text { Fire-exposed header's in 8-or 12-in. rolok walls } \\
\text { Unexposed stretchers in 12-in. rolok wall } \\
\text { Unexposed headers in 12-in. rolok wall }\end{array}$ & 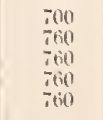 & $\begin{array}{l}25 \\
15 \\
15 \\
6 \\
6\end{array}$ & $\begin{array}{l}-3.11 \\
-5.5 \\
-1.2 .9 \\
-10.4 \\
-5.4\end{array}$ \\
\hline $\begin{array}{l}\text { CLI } \\
\text { CLI } \\
\text { SH W } \\
\text { SHW } \\
\text { SHW }\end{array}$ & 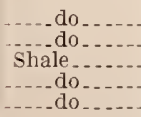 & 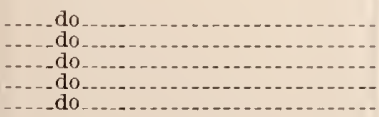 & $\begin{array}{l}\text { Fire-exposed stretehers in 8-in. rolok walls } \\
\text { Fire-exposed headers in 8-in. rolok wulls } \\
\text { Fire-exposed stretehers in 8-inl. rolok wills } \\
\text { Fire-exposed headers in 8-in. rolok wills. } \\
\text { Unexposed stretehers in 8-in. rolok walls. }\end{array}$ & 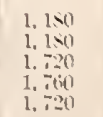 & $\begin{array}{l}16 \\
17 \\
15 \\
15 \\
15\end{array}$ & $\begin{array}{r}-51.3 \\
-3.3 \\
-\because 1 \\
-34.4 \\
+4.4\end{array}$ \\
\hline
\end{tabular}


Some of the loss was due to damage to the masonry specimen incurred in cutting it out of the wall after test. It might also be noted that the tests were made with specimens about $2 \frac{1}{2} \mathrm{ft}$ high, and the effect on strength, such as from loss of header bond in the fire test, would not be as much as with specimens of greater height.

\section{Summary and Conclusions}

\subsection{Materials of Construction}

The bricks included a representative range in kind and quality and met AS'TM specifications from the standpoint of strength and other properties, for use in interior or exterior walls of buildings (table 1 ).

The portland cement, lime, plaster', and sand also met recognized acceptance standards. The mortar strengths (table 2) were somewhat lower than prescribed for given proportions, apparently due to the wet mix, the samples being taken from the mortar prepared by the workmen constructing the walls.

\subsection{Workmanship}

The workmanship for most of the large solid and all-rolok hollow walls was hardly up to the usual standard for building construction. This applied particularly to the filling and pointing of mortar joints at the surface of unplastered walls.

The strength of the masonry as based on compressive tests of piers (table 5) had a factor of safety of 3 or more on working loads applicable for given wall designs.

\subsection{Wall Constructions}

The walls tested were of designs representative of those in common use, and some new designs were included that as yet have found only limited application in building construction. They were subjected to fire test restrained within heavy panel frames, unrestrained with freedom to deflect outward at the top, and under applied working loads. The heights of the large walls were representative of moderate story heights of buildings. Supplementary information was obtained with walls or smaller size.

\subsection{Testing Procedure}

The furnace fire exposure was controlled according to the present procedure for conduct of fire tests [8], except that, in the earlier tests going beyond $8 \mathrm{hr}$, the furnace temperature was raised above $2,300^{\circ} \mathrm{F}$ to a maximum of $2,500^{\circ} \mathrm{F}$ (sec. 4.4(a)). The comparison on severity of furnace exposure given in tables 9 and 10 was based on the area under the furnace curve of the present standard, hence the severity in some of these earlier tests of long duration appears relatively high. Otherwise, the furnace control was well within permitted tolerance limits.

In the earlier tests, the method of determining temperatures on the unexposed surface had not been standardized, but sufficient information was obtained in these and later tests to evaluate results in terms of the present procedure.

The procedure used in some of the fire and hosestream tests differed in only minor details from the present procedure with respect to the nozzle pressure and duration of the hose-stream application. Although no load was applied in these earlier tests, the evidence appears conclusive (sec. 7.3) that the walls would have sustained the working load during the test and twice this load after cooling, if tested according to the present procedure [8]. On other aspects, the test data indicated that the walls fully met the requirements of the test (sec.7.1 and 7.2).

\subsection{Conditioning Before Test}

For the 4 -in. walls and the 8 -in. walls of clay or shale bricks, the conditioning procedure used (sec. 3.5) apparently resulted in a degree of dryness within the range attained by walls within heated buildings. Concrete and sand-lime bricks are more retentive of moisture, and for them, as well as for all 12-in. solid walls and 8- and 12-in. plastered walls, the desired degree of dryness may not have been attained.

A number of the walls were dried to constant weight at temperatures in the range $160^{\circ}$ to $180^{\circ}$ $\mathrm{F}$, and in the general evaluation of the results of the tests, due consideration is given to their performance in the fire test in comparison with the results obtained with walls seasoned under room conditions.

\subsection{Fire-Resistance Periods}

The main result of this type of fire test is the time the construction withstands the test under the given performance limits. The limiting condition may be failure under working load or collapse from excessive lateral deflection, certain temperature-rise limits reached within the wall or on the surface not exposed to fire, passage of flame, or ignition of combustible material in contact on the unexposed side. Satisfactory performance in the fire and hose-stream test is also a corollary requirement.

The fire-resistance periods are based upon the events during the test while the construction was exposed to fire. Subsequent occurrences (tables 11 and 12), such as increase in temperature rise on the unexposed side and ignition of pads in contact therewith, are not considered of direct concern. In the fire test, the furnace temperature was at or near maximum at the end of the fire exposure, and the subsequent heat from the furnace was, in effect, a continuation of the test of the wall in place at the furnace. 
Also, high temperatures of fires in buildings are not generally sustained for long periods, and the cooling periods are longer than those for the test furnace. Thus, in fire severity tests with combustibles burned under representative conditions in buildings, the maximum temperatures were reached relatively early, but the greater part of the area under the time-temperature curve serving as a measure of fire severity, was obtained in the subsequent period.

Accordingly, fire-division walls in buildings having a fire-resistance equal to the fire severity to be expected should give protection during both the active period of the fire and subsequently. The fire resistance of brick walls is relatively high, and the thickness required for other reasons will generally give the required fire resistance. However, this is not always the case, particularly where hot debris remains in contact with the wall. Hence, the possibility that materials on the unexposed side or combustible members framed into the wall will ignite after the fire is under control, or eren after extinguishment. This is attested by such occurrences in building fires.

\section{a. Theoretical Relations}

For the conditions of the fire test it has been found that, with constructions of the same material, the time of the limiting temperature rise at points within the wall or on the unexposed surface varies with the 1.7 power of the thickness of solid material intervening between these points and the fire-exposed surface [7]. Furthermore, the effect of plaster and of the air spaces in the construction can be eraluated on a similar basis [9].
Use will be made of these relations only in comparing results with similar walls of different thireknesses and in appraising results in which the degree of conditioning or size of wall may have had significant effects.

\section{b. Loading and Stability}

In the fire tests, the 4- and 8-in. solid and allrolok walls carried working loarls up to or beyorirl the time when temperature-rise limits were reacherl on the unexposed side. For the 10-in. cavity wall, an adjustment in the working load had to be marle before this condition was met. For 12-in. solid walls of clay bricks having a low softening point and for those of sand-lime bricks having a compressive strength of less than $2,500 \mathrm{lb} / \mathrm{in}^{2}{ }^{2}$, there was failure under load before the limiting temperature rise was reached on the unexposed side.

With these exceptions, the walls shown to have given fire-resistance periods can be considered as able to carry up to these limits the working loads appropriate for their design, thickness, brick material, and mortar.

There was no collapse in the tests of unloaded walls because of excessive lateral deflection.

\section{c. Average Fire-Resistant Periods}

Fire-resistance periods or limits of brick walls of solid and hollow designs are given in table 17 , as based upon results from the present tests. They are given to the nearest $1 / 4 \mathrm{hr}$ up to $2 \mathrm{hr}$, to the nearest $1 / 2 \mathrm{hr}$ in the range from $2 \mathrm{hr}$ to $4 \mathrm{hr}$, and to the nearest hour above $4 \mathrm{hr}$.

TABLE 17. Fire-resistance periods of brick walls

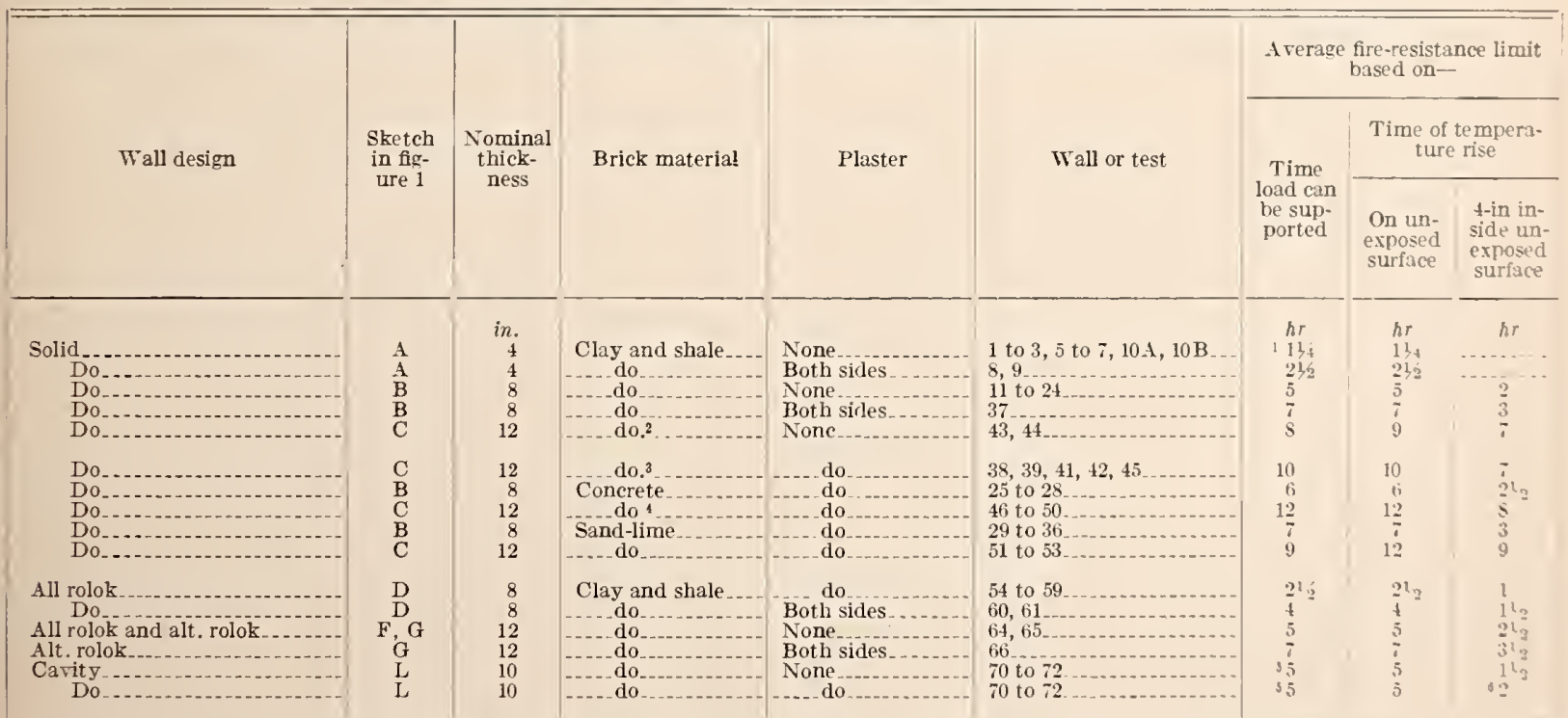

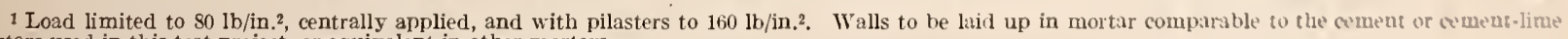
mortars used in this test project, or equivalent in other mortars

2 Bricks of burned clay and shale having softening point below $2,200^{\circ} \mathrm{F}$.

3 Bricks of burned clay and shale having softening point of $2,200^{\circ} \mathrm{F}$ or over.

4 o cinders or other constituents in the aggregate that lower the softening point of the concrete below $2,300^{\circ} \mathrm{F}$

- Working load limited to one-third of load allowed for 8-in. solid brick walls of comparable material.

6 Based on embedment of ends of combustible members on not less than three sides. 
The values in table 17 are below the average result with a group of comparable walls but were not as low as the minimum in all cases. Further reductions were made on account of size and degree of seasoning of the walls.

The increase credited for plaster is based upon coatings of not less than $5 / 8$ in. thickness of gypsum or portland-cement plaster, comparable to those applied in connection with these tests. For periods determined by temperature rise on the unexposed side, the plaster is assumed to be applied on both sides of the wall. Where determined by bearing capacity or protection of ends of combustible members 4-in. inside the unexposed surface, the plaster need be applied only on the fire-exposed side.

(1) Clay-and shale-brick walls of 4-in. thickness. The limit of $1 \frac{1}{4} \mathrm{hr}$ for the unplastered wall is based upon an average test result for the group of $1 \mathrm{hr} 21 \mathrm{~min}$, the minimum in any test being 1 hr 8 min. Here little or no discount need be made for size of wall or degree of seasoning. Shalebrick wall 6 and clay-brick wall 2 carried a load of $80 \mathrm{lb} / \mathrm{in} .^{2}$ for $1 \mathrm{hr} 44 \mathrm{~min}$ and $2 \mathrm{hr} 20 \mathrm{~min}$, respectively. The results of tests $10 \mathrm{~A}$ and $10 \mathrm{~B}$ indicate that with pilasters (fig. 2) the load can be increased to $160 \mathrm{lb} / \mathrm{in}^{2}$

(2) Solid clay-and shale-brick walls of 8 - and 12-in. thickness. The $5 \mathrm{hr}$ period for unplastered walls is within the limits determined in the tests with normally seasoned walls. The average limit of temperature rise in the wall of $2 \mathrm{hr}$ compares with the average from 12 tests of $2 \mathrm{hr} 16 \mathrm{~min}$.

The periods given for plastered walls are lower than the results with plastered wall 37 , both because of size of wall and degree of dryness. They are in accord with a conservative interpretation of results obtained with plaster and also with theoretical relations [9]. Similar considerations were applied in the derivation of periods for the 12 -in. walls.

(3) Solid concrete and sand-lime brick walls of 8- and 12-in. thickness. In arriving at the periods listed in table 17, due consideration was given to the degree of dryness of the walls at the time of test and the possible effect of border conditions for other than the large walls. The periods given for the walls of 12-in. thickness and those more fully experimentally determined for the 8-in. walls are in general theoretical accord. The aggregate for concrete bricks in 12-in. walls should contain no cinders or other constituents that unduly lower the fusion point. Allowance was made for the extra width of sand-lime bricks from source SLD.

(4) Walls of all-rolok and alternate rolok designs. For the unplastered walls, the limits given in table 17 are taken at or a little below the average results from the tests. The periods arrived at for the plastered walls are below experimental values that apparently were unduly influenced by degree of seasoning before test and cooling from the borders during test.

(5) Cavity walls. Only the cavity wall of nominal 10 -in. thickness was included in the tests, and the fire-resistance periods in table 17 are near the a verage of the test results.

(6) Walls of other designs. A number of walls of rolok-bak and rolok-faced designs were included in the series, and while the results are informative, they do not form an adequate basis for evaluation in terms of fire-resistance periods, pending accrual of additional information from further fire tests.

Acknowledgments are made to a number of former members of the Fire Resistance Section of the National Bureau of Standards for conduct of tests and reducing the large volume of test data to usable form, among whom mention is here made of Clement R. Brown, Nolan D. Mitchell, and Harry E. Newcomer. Acknowledgments are also made to William Carver, formerly architect with the Common Brick Manufacturers Association of America, for development of a number of the hollow wall designs, and to C. O. Christianson, Research Associate with the Association, for assistance on fire tests of the walls.

\section{References}

[1] S. H. Ingberg and H. D. Foster, Fire resistance of hollow load-bearing wall tile, BS J. Research 2, 27 (1929) RP37.

[2] S. H. Ingberg and Nolan D. Mitchell, Fire tests of wood- and metal-framed partitions, NBS Building Materials and Structures Report BMS71 (1941).

[3] Harry D. Foster, Earl R. Pinkston, and S. H. Ingberg, Fire resistance of walls of lightweight-aggregate concrete masonry units, NBS Building Materials and Structures Report BMS1] 7 (1950).

[4] Harry D. Foster, Earl R. Pinkston, and S. H. Ingberg, Fire resistance of walls of gravel-aggregate concrete masonry units, NBS Building Materials and Structures Report BMS120 (1951).

[5] S. H. Ingberg, H. K. Griffin, W. C. Robinson, and R. E. Wilson, Fire tests of building columns, BS Tech. Pap. T184, p. 99-106 (1921).

[6] Standard specifications for fire tests of building construction and materials, American Society for Testing Materials Designation C19-33 or American Standards Association No. A2-1934.

[7] S. H. Ingberg, Size and border conditions of test specimens in their relation to results of fire tests, Am. Soc. Testing Materials Proc. 49, p. 1065-77 (1949).

[8] Standard methods of fire tests of building construction and materials, American Society for Testing $\mathrm{Ma}-$ terials Designation E119-50.

[9] Fire-resistance classifications of building constructions, NBS Building Materials and Structures Report BMS92, Appendix B (1942).

Washington, April 19, 1954. 
[Continued from cover page II]

BMS32 Structural Properties of Two Brick-Concrete-Block Wall Constructions and a ConcreteBlock Wall Construction Sponsored by the National Concrete Masonry Association.

BMS33

BMS34

BMS35

BMS36

BMS37

BMS38

BMS39

BMS40

BMS41

BMS42

BMS43

BMS44

BMS45

BMS46

BMS47

BMS48

BMS49

BMS50

BMS51

BMS52

BMS53

BMS54

BMS55

BMS56

BMS57

BMS58

BMS59

BMS60

BMS61

BMS62

BMS63

BMS64

BMS65

BMS66

BMS67

BMS68

BMS69

BMS70

BMS71

BMS72

BMS73

BMS74

BMS75

BMS76

BMS77

BMS78

BMS79

BMS80

BMS81

BMS82

BMS83

BMS84
Plastic Calking Materials

Performance Test of Floor Coverings for Use in Low-Cost Housing: Part 1

Stability of Sheathing Papers as Determined by Accelerated Aging.

Structural Properties of Wood-Frame Wall, Partition, Floor, and Roof Constructions

With "Red Stripe" Lath Sponsored by The Weston Paper and Manufacturing Co_.

Structural Properties of "Palisade Homes" Constructions for Walls, Partitions, and Floors, Sponsored by Palisade Homes.

Structural Properties of Two "Dunstone" Wall Constructions Sponsored by the W. E. Dunn Manufacturing Co

Structural Properties of a Wall Construction of "Pfeifer Units" Sponsored by the Wisconsin Units Co.

Structural Properties of a Wall Construction of "Knap Concrete Wall Units" Sponsored by Knap America, Inc.

Effect of Heating and Cooling on the Permeability of Masonry Walls

Structural Properties of Wood-Frame Wall and Partition Construction with "Celotex"

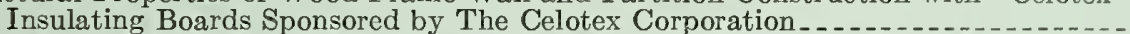

Performance Test of Floor Coverings for Use in Low-Cost Housing: Part 2

Surface Treatment of Steel Prior to Painting.

Air Infiltration Through Windows.

Structural Properties of "Scott-Bilt"' Prefabricated Sheet-Steel Construction for Walls, Floors, and Roofs Sponsored by The Globe-Wernicke Co_

Structural Properties of Prefabricated Wood-Frame Constructions for Walls, Partitions, and Floors Sponsored by American Houses, Inc

Structural Properties of "Precision-Built" Frame Wall and Partition Constructions Sponsored by the Homasote Co.

Metallic Roofing for Low-Cost House Construction

Stability of Fiber Building Boards as Determined by Accelerated Aging

Structural Properties of "Tilecrete Type A" Floor Construction Sponsored by the Tilecrete Co.

Effect of Ceiling Insulation Upon Summer Comfort

Structural Properties of a Masonry Wall Construction of "Munlock Dry Wall Brick" Sponsored by the Munlock Engineering Co_._.

Effect of Soot on the Rating of an Oil-Fired Heating Boiler

Effects of Wetting and Drying on the Permeability of Masonry Walls

A Survey of Humidities in Residences

Roofing in the United States-Results of a Questionnaire

Strength of Soft-Soldered Joints in Copper Tubing

Properties of Adhesives for Floor Coverings

Strength, Absorption, and Resistance to Laboratory Freezing and Thawing of Building Bricks Produced in the United States

Structural Properties of Two Nonreinforced Monolithic Concrete Wall Constructions.-

Structural Properties of a Precast Joist Concrete Floor Construction Sponsored by the Portland Cement Association.

Moisture Condensation in Building Walls

Solar Heating of Various Surfaces

Methods of Estimating Loads in Plumbing Systems

Plumbing Manual Partitions, Floors, and Roofs Sponsored by Herman A. Mugler

Performance Test for Floor Coverings for Use in Low-Cost Housing: Part 3.....

Stability of Fiber Sheathing Boards as Determined by Accelerated Aging

Asphalt-Prepared Roll Roofings and Shingles.

Fire Tests of Wood- and Metal-Framed Partitions_._.

Structural Properties of "Precision-Built, Jr." Prefabricated Wood-Frame Wall Construction Sponsored by the Homasote Co

Indentation Characteristics of Floor Coverings.

Structural and Heat-Transfer Properties of "U. S. S. Panelbilt" Prefabricated SheetSteel Constructions for Walls, Partitions, and Roofs Sponsored by the Tennessee Coal, Iron \& Railroad Co.

Survey of Roofing Materials in the North Central States

eft outdoor Exposure on the Water Permeability of Masonry Walls_........... Sroperties and Performance of Fiber Tile Boards Constructions

Water-Distributing Systems for Buildings

Performance Test of Floor Coverings for Use in Low-Cost Housing: Part 4

Field Inspectors' Check List for Building Constructions (cloth cover, 5 x $7 \%$ inches) _. 35 e

Water Permeability of Walls Built of Masonry Units

Strength of Sleeve Joints in Copper Tubing Made With Various Lead-Base Solders ... 15e

Survey of Roofing Materials in the South Central States _. (a) 40 é

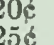
, . . s. * ?

\section{$\log$}

\section{$x^{*}$}

* Out of print.

[List continued on cover page IV] 


\section{BUILDING MATERIALS AND STRUCTURE REPORTS}

[Continued from cover page III]

BMS85 Dimensional Changes of Floor Coverings With Changes in Relative Humidity and Temperature

BMS86 Structural, Heat-Transfer, and Water-Permeability Properties of "Speedbrik" Wall Construction Sponsored by the General Shale Products Corporation---

BMS87 A Method for Developing Specifications for Building Construction-Report of Subcommittee on Specifications of the Central Housing Committee on Research, Design, and Construction

BMS88 Recommended Building Code Requirements for New Dwelling Construction With Special Reference to War Housing

BMS89 Structural Properties of "Precision-Built, Jr." (Second Construction) Prefabricated Wood-Frame Wall Construction Sponsored by the Homasote Co

BMS90

BMS91

BMS92

BMS93

BMS94

Structural Properties of "PHC" Prefabricated Wood-Frame Constructions for Walls, Floors, and Roofs Sponsored by the PHC Housing Corporation A Glossary of Housing Terms._. Fire-Resistance Classifications of Building Constructions. Water Permeability and Weathering Resistance of Stucco-Faced, Gunite-Faced, and "Knap Concrete-Unit" Walls

BMS95

BMS96

BMS97

BMS98

BMS99

BMS100

BMS101

BMS102

BMS103

BMS104

BMS105

BMS106

BMS107

BMS108

BMS109

BMS110

BMS111

BMS112

BMS113

BMS114

BMS115

BMS116

BMS117

BMS118

BMS119

BMS120

BMS121

BMS122

BMS123

BMS124

BMS125

BMS126

BMS127

BMS128

BMS129

BMS130

BMS131

BMS132

BMS133

BMS134

BMS135

BMS136

BMS137

BMS138

BMS139

BMS140

BMS141

BMS142

BMS143

Tests of Cement-Water Paints and Other Waterproofings for Unit-Masonry Walls.--

Properties of a Porous Concrete of Cement and Uniform-Sized Gravel Experimental Dry-Wall Construction With Fiber Insulating Board Physical Properties of Terazzo Aggregates Structural and Heat-Transfer Properties of "Multiple Box-Girder Plywood Panels" for Walls, Floors, and Roofs

Relative Slipperiness of Floor and Deck Surfaces

Strength and Resistance to Corrosion of Ties for Cavity Walls

Painting Steel-(-

Measurements of Heat Losses From Slab Floors

Structural Properties of Prefabricated Plywood Lightweight Constructions for Walls, Partitions, Floors, and Roofs Sponsored by the Douglas Fir Plywood Association Paint Manual with particular reference to Federal Specifications Laboratory Observations of Condensation in Wall Specimens. Building Code Requirements for New Dwelling Construction Temperature Distribution in a Test Bungalow With Various Heating Devices.-..- $15 \phi$ Strength of Houses: Application of Engineering Principles to Structural Design-.-- $\$ 1.75$ Paints for Exterior Masonry Walls Performance of a Coal-Fired Boiler Converted to Oil Properties of Some Lightweight-Aggregate Coneretes With and Without an AirEntraining Admixture.... Fire Resistance of Structural Clay Tile Partitions Temperature in a Test Bungalow With Some Radiant and Jacketed Space Heaters.-- $25 \phi$ A Study of a Baseboard Convector Heating System in a Test Bungalow_....... Preparation and Revision of Building Codes............ Fire Resistance of Walls of Lightweight Aggregate Concrete Masonry Units.... 25 Stack Venting of Plumbing FixturesWet Venting of Plumbing Fixtures Fire Resistance of Walls of Gravel-Aggregate Concrete Masonry Units... Investigation of Failures of White-Coat Plasters Physical Properties of Some Samples of Asbestos-Cement Siding Fire Tests of Wood-Framed Walls and Partitions With Asbestos-Cement Facings.-. 15\% Fire Tests of Steel Columns Protected With Siliceous Aggregate Concrete. Stone Exposure Test Wall The Self-Siphonage of Fixture Traps Effect of Aging on the Soundness of Regularly Hydrated Dolomitic Lime Putties.-. $15 \phi$ Atmospheric Exposure Tests of Nailed Sheet Metal Building Materials Fire Endurance of Shutters for Moving-Stairway Openings Methods and Equipment for Testing Printed-Enamel Felt-Base Floor Covering-..- 15 Fire Tests of Gunite Slabs and Partitions Capacities of Plumbing Stacks in Buildings. Live Loads on Floors in Buildings Fire Resistance of Concrete Floors Fire Tests of Steel Columns Encased With Gypsum Lath and Plaster... Properties of Cavity Walls Influence of the Wash From Bronze on the Weathering of Marble of Edge Insulation Upon Temperature and Condensation on Concrete-slab $15 \phi$ Floors Studies of Stone-Setting Mortars Selected Bibliography on Building Construction and Maintenance Fire Endurance of Open-Web Steel-Joist Floors With Concrete Slabs and Gypsum Ceilings

Frost Closure of Roof Vents Fire Tests of Brick Walls...

* Out of print.

tSuperseded by BMS107. 